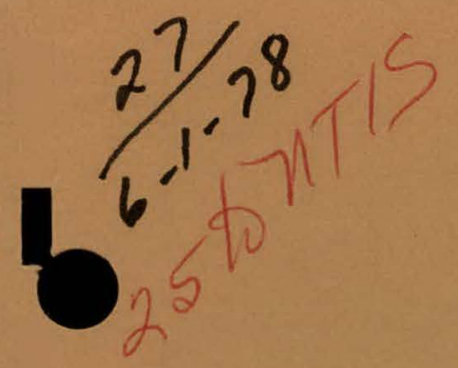

\title{
Western Gas Sands Project Status Report
}

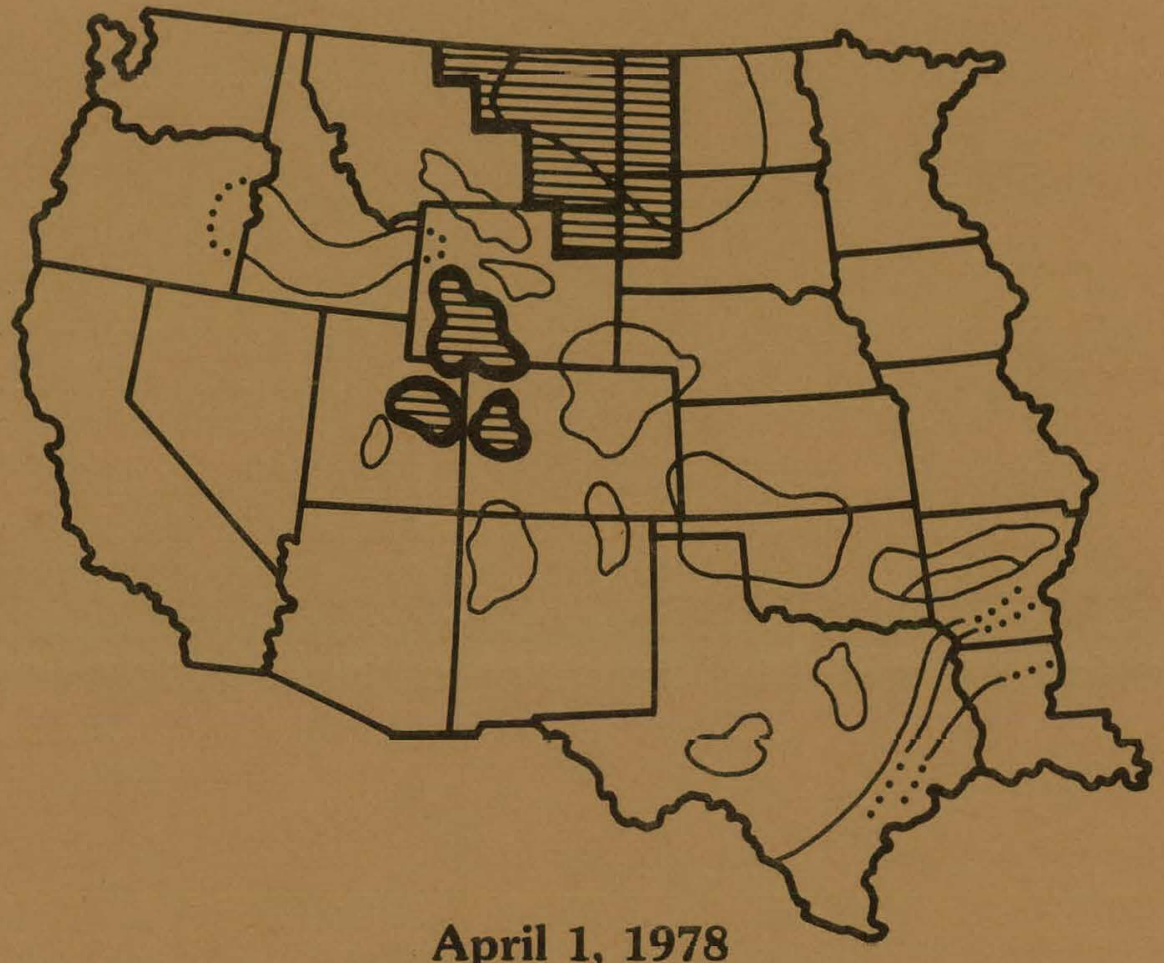

April 1, 1978

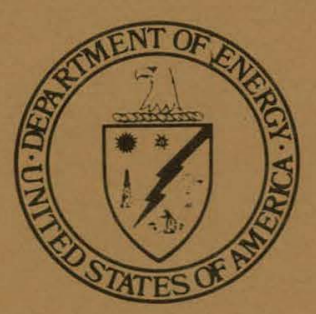

Prepared for

U.S. Department of Energy

Bartlesville Energy Research Center

Charles $\mathrm{H}$. Atkinson

Project Manager

Compiled by CER Corporation

Las Vegas, Nevada

Contract EY-76-C-08-0655 


\section{DISCLAIMER}

This report was prepared as an account of work sponsored by an agency of the United States Government. Neither the United States Government nor any agency Thereof, nor any of their employees, makes any warranty, express or implied, or assumes any legal liability or responsibility for the accuracy, completeness, or usefulness of any information, apparatus, product, or process disclosed, or represents that its use would not infringe privately owned rights. Reference herein to any specific commercial product, process, or service by trade name, trademark, manufacturer, or otherwise does not necessarily constitute or imply its endorsement, recommendation, or favoring by the United States Government or any agency thereof. The views and opinions of authors expressed herein do not necessarily state or reflect those of the United States Government or any agency thereof. 


\section{DISCLAIMER}

Portions of this document may be illegible in electronic image products. Images are produced from the best available original document. 
This report was prepared as an account of work sponsored by the United States Government. Neither the United States nor the United States DOE, nor any of their employees, nor any of their contractors, subcontractors, or their employees, makes any warranty, express or implied, or assumes any legal liability or responsibility for the accuracy, completeness, or usefulness of any information, apparatus, product or process disclosed, or represents that its uco would nnt infringe privately owned rights.

Available from the National Technical Information Service, U.S. Department of Commerce, Springfield, Virginia 22161.

\begin{tabular}{|c|c|c|c|c|c|c|c|c|c|c|c|}
\hline \multirow[b]{2}{*}{$\begin{array}{l}\text { Page } \\
\text { range }\end{array}$} & \multicolumn{10}{|c|}{$\begin{array}{l}\text { NATIONAL TECHNICAL INFORMATION SERVICE PAPER COPY PRICES } \\
\text { EFFECTIVE JAN. } 1,1976\end{array}$} & \multirow[b]{2}{*}{$\begin{array}{c}\text { Domestic } \\
\text { price }\end{array}$} \\
\hline & $\begin{array}{l}\text { Domestic } \\
\text { price }\end{array}$ & $\begin{array}{l}\text { Page } \\
\text { range }\end{array}$ & $\begin{array}{l}\text { Domestic } \\
\text { price }\end{array}$ & $\begin{array}{l}\text { Page } \\
\text { range }\end{array}$ & $\begin{array}{l}\text { Domestic } \\
\text { price }\end{array}$ & $\begin{array}{l}\text { Page } \\
\text { range }\end{array}$ & $\begin{array}{l}\text { Domestic } \\
\text { price }\end{array}$ & $\begin{array}{l}\text { Page } \\
\text { range }\end{array}$ & $\begin{array}{l}\text { Domestic } \\
\text { price }\end{array}$ & $\begin{array}{l}\text { Page } \\
\text { range }\end{array}$ & \\
\hline $101-025$ & $\$ 3.50$ & $126 \cdot 150$ & $\$ 6.00$ & $251-275$ & $\$ 9.00$ & 376.400 & $\$ 10.75$ & 501.525 & $\$ 12.75$ & $701 \cdot 800$ & $\$ 18.75$ \\
\hline $026-0.50$ & $\$ 4,00$ & 1.175 & $\$ 6.75$ & $276-300$ & $\$ 9.25$ & 401.425 & $\$ 11.00$ & $526-550$ & $\$ 13.00$ & $801 \cdot 900$ & $\$ 21.25$ \\
\hline 051.07 & $\$ 4.5$ & 176.200 & $\$ 7.50$ & 301.325 & $\$ 9.75$ & 426.450 & $\$ 11.75$ & 5511.5795 & $\$ 13.50$ & $901 \cdot 1000$ & $\$ 23.75$ \\
\hline $076 \cdot 100$ & $\$ 5.00$ & 201.225 & $\$ 7.75$ & $326-350$ & $\$ 10.00$ & $451-475$ & $\$ 12.00$ & $576: 600$ & $\$ 13.75$ & $1001 \cdot 1100$ & $\$ 28.25$ \\
\hline $101 \cdot 125$ & $\$ 5.50$ & $226-250$ & $\$ 8.00$ & $351-375$ & $\$ 10.50$ & 476-500 & $\$ 12.50$ & $601-700$ & $\$ 16.25$ & $1101 \cdot 1200$ & $\$ 32.75$ \\
\hline
\end{tabular}

For additional pages, add $\$ 1.50$ for ear.h beginning 100 pages. Add $\$ 2.50$ per copy for foreign price.

Microficlie $\$ 3.00$ (domestic) $\$ 4,50$ (foreign). 


\section{CONTENTS}

Page

1. SUMMARY . . . . . . . . . . . . . . . . . . . . . 1

2. PROJECT MANAGEMENT . . . . . . . . . . . . . . . . . . . . . 3

3. RESOURCE ASSESSMENT • . . . . . . . . . . . . . . . . . 5

3.1 U.S. Geolngical Survey Activities . . . . . . . . 5

3.2 Coring Program . . . . . . . . . . . . . . . 7

3.3 Study of Basin Activities . . . . . . . . . . . 7

4. RESEARCH AND DEVELOPMENT BY ENERGY RESEARCH CENTERS

AND NATIONAL LABORATORIES . . . . . : . . . . . • . 17

4.1 Bartlesville Energy Research Center (BERC) - . . . 17

4.2 Lawrence Livermore Laboratory (LLL) . . . . . . . 20

4.3 Sandia Laboratories . . . . . . . . . . . . . . 25

4.4 U.S. Geological Survey (USGS) Borehole

Gravity Meter . . . . . . . . . . . . . 30

4.5 U.S. Geological Survey/Menlo Park - Tiltmeter . . . 30

5. FIELD TESTS AND DEMONSTRATIONS . • . • . . . . . . . • . 31

5.1 Background . . . . . . . . . . . . . . . . 31

5.2 CER Corporation . . . . . . . . . . . . . . 35

5.3 Colorado Interstate Gas Company . . . . . . . . . . 37

5.4 Gas Producing Enterprises Inc. ... . . . . . . . . . 39

5.5 Mobil Research and Development Corpuration . . . . : 63

5.6 Rio Blanco Natural Gas Company . . . . . . . . . . . 68

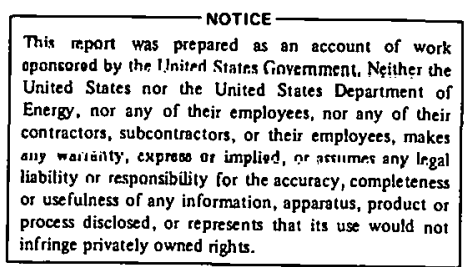

infringe privasely owned rights. that its use would not

.

ii. 


\section{FIGURES}

$\underline{\text { Page }}$

FIGURE 3-1 STEROSCAN SCANNING ELECTRON MICROSCOPE . . . . . . 6

FIGURE 3-2 PICEANCE BASIN . . . . . . . . . . . . . 8

FIGURE $3-3$ GREATER GREEN RIVER BASTN . . ............ 10

FIGURE 3-4 UINTA BASIN . . . . . . . . . . . . . . 12

FIGURE 3-5 NORTHERN GREAT PLAINS PROVINCE . . . . . . . . . 14

FIGURE 4-1 APPARATUS FOR CORING TEST ............. 18

FIGURE 4-? . ROKK CORFI WITH DC 200 . . . . . . . . . . . . . . . .

FIGURE 4-3 LAYER EFFECTS NEAR A VERTICAL HYDROFRACTURE . . . . 22

FIGURE 4-4 MODEL PRESSURE BUILDUP . . . . . . . . . . . . . 24

FIGURE 4-5 HYDRAULICALLY DRIVEN CRACK NEAR UNBONDED

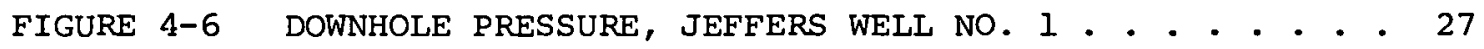

FIGURE 4-7 CURRENT MINEBACK ACTIVITIES, G TUNNEL, NEVADA

TEST SITE . . . . . . . . . . . . 28

FIGURE 5-1 FLOW RATE PERFORMANCE OF NATURAL BUTTES
NO. 14 WELL . . . . . . . . . . . . . . . . 40

FIGURE 5-2. NATURAL BUTTES NO. 14 WELL SHOWING SANDS

FRACTURED . . . . . . . . . . . . . . . 41

FIGURE 5-3 FLOW RATE PERFORMANCE OF NATURAL BUTTES
NO. 18 WELL . . . . . . . . . . . . . . 46

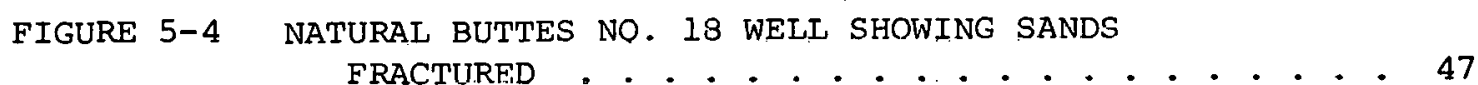

FIGURE 5-5 FLOW RATE PERFORMANCE OF NATURAL BUTTES
NO. 19 WELL . . . . . . . . . . . . . . . 52

FIGURE 5-6 NATURAL BUTTES NO. 19 WELI SHOWING SANDS
FRACTURED . . . . . . . . . . . . . 53 
FIGURE 5-7 FLOW RATE PERFORMANCE OF NATURAL BUTTES NO. 20 WELL . . . . . . . . . . . . . . . 59

FIGURE 5-8 NATURAL BUTTES NO. 20 WELL SHOWING SANDS FRACTURED . . . . . . . . . . . . . . . 60

FIGURE 5-9 MOBIL F-31-13G WELL SHOWING SANDS FRACTURED . . . . . . . . . . . . . . . . 65

FIGURE 5-10 RIO BLANCO NATURAL GAS FEDERAL 498-4-1 WELL SHOWING SANDS FRACTURED . . . . . : . . . . . 70

\section{TABLES}

TABLE 4-1 DENSITY AND POROSITY OF UEgIO\#6 CORE SAMPLES • • • • 29

TABLE 5-1 MHF CONTRACT LOCATIONS AND FRAC DATA • . . . • . . 32

TABLE 5-2 MOBIL WELL F-31-13G PRODUCTION DATA . . . . . . . . 64

TABLE 5-3 RIO BLANCO NATURAL GAS NO: 498-4-1 WELL,

FOUR POINT FLOW TEST . . . . . . . . . . 69 


\section{SUMMARY}

This report summarizes the progress of the major government sponsored projects undertaken to increase gas production from the low permeability gas sands of the western United States during February, 1978. Background information is given in the september 1977 Status Report, NVO/0655-100.

The Western Gas Sands Project Core Program, January 12, 1978 document has been distributed.

The Western Gas Sands Project files, which contain raw data and pubiished reports from each Western Gas Sands Project participant have been established. A log file containing logs from pertinent wells in the four study areas has also been established.

The U.S. Geological Survey (USGS) is continuing geological and geophysical studies in the four study areas for resource assessment. A number of papers ylviny lesults of rcaont investigatinns were presented at meetings during the month.

The Bartlesville Energy Research Center (BERC) and participating National Laboratories are continuing their work in research and development.

Field tests and demonstrations continue in the Uinta and Piceance Basins at the following locations:

Uinta Basin

Gas Producing Enterprises, Inc. (GPE)

Natural Buttes Unit Wells No. 14, 18, 19, 20, 21, and 22

\section{Piceance Basin}

Mobil Research and Development Corporation

We1l No. F-31-13G

Rio Blanco Natural Gas Company

Well No. 498-4-1 


\section{THIS PAGE \\ WAS INTENTIONALLY \\ LEFT BLANK}




\section{PROJECT MANAGEMENT}

The Western Gas Sands Project Core Program, January 12, 1978, document has been distributed to Western Gas Sands Project (WGSP) participants. It establishes handling procedures and planned analyses, and reflects inputs from the January, 1973 coordination meeting held at CER Corporation's office in Las Vegas, Nevada.

Mitchell Energy Company's proposal to conduct an MHF test in the Cotton Valley limestone gas reservoir in Texas has been approved and the contract has been written in preparation for negotiations.

The Western Gas Sands Project files have been established which contain raw data and published reports from each Western Gas Sands Project participant. A well log file has also been established at the CER Corporation office in Las Vegas.

The Project Plan Document FY 78 is being reviewed in Washington, D.C. and is expected to be finalized soon. Participants of the WGSP will be requested to submit their schedule status along with their monthly activity reports. The Project Plan Document FY 79 is being drafted

Work is proceeding on the Project Implementation Plan and the second Quarterly Basin Activity Report.

Arrangements were completed for the Fourth Semi-Annual Review Meeting on Enhanced Gas Recovery (EGR) to be held. in Las Vegas on March 21, 22 and 23, 1978. Participants and selected contractors were contacted to solicit participation and agenda items for the meeting.

CER personnel visited GO International in Ft. Worth, Texas to inspect the mast truck and trailer being assembled there and met with Sandia Laboratories personnel to review the status of the mobile data collection trailer.

CER, in conjunction with the profect Manager, completed a study on speculative gas resources in western tight gas sands at DOE Headquarters request. Results of this work will be incorporated in the Lewin \& Associates study of EGR strategies.

Geophysical logs from Gas Producing Enterprises,' (GPE) Natural Buttes Unit Well No. 21 were analyzed in preparation for a meeting in March with GPE to select the individual sands to be tested. 
THIS PAGE

\section{WAS INTENTIONALLY \\ LEFT BLANK}




\title{
3. RESOURCE ASSESSMENT
}

Resource assessment includes geological, geophysical and reservoir evaluation studies to define and characterize the resource base. The U.S. Geological Survey (USGS) is performing the majority of the geological studies for resource assessment. Additional activity, however, primarily in the area of field tests and obtaining and analyzing cores, provides data to support its work.

\subsection{U.S. Geological Survey Activities}

\subsubsection{Northern Great Plains Province}

Results of recent investigations were presented in talks at the following meetings :

\author{
USGS Seminar on Petroleum Research and Resources, \\ March 14, 1978, Golden, Colorado \\ Rocky Mountain Section of the AAPG-SEPM, Salt Lake City, Utah
}

Two papers are in preparation for the Williston Basin Symposium.

Compilation of subsurface and other data is continuing.

\subsubsection{Greater Green River Basin}

C.W. Spencer presented an oral summary of the Western Gas Sands Project at the USGS Seminar on Petroleum Research and Resources. In addition, a preliminary lineament and geomorphic anomaly map was prepared on the Washakie and Great Divide Basins using enhanced LANDSAT photos.

T.F. Tyler discussed a preliminary evaluation of low permeability reservoirs in the Washakie Basin at the USGS Seminar, and sent three log cross-section panels to the USGS Technical Reports Unit for review.

K.W. Kitely presented a paper on "Stratigraphy of the Mesaverde Group and Occurrence of Natural Gas in Northwest Colorado," at the AAPG-SEPM meeting. An abstract of the paper will be published in the AAPG Bulletin. Data was also compiled on gas fields and production in the Sand Wash Basin, Colorado.

Eight samples were submitted for paleontologic and thermal maturation analysis.

Work is continuing on the correlation of log cross-sections in all basins. 


\subsubsection{Piceance Basin-Uinta Basin}

The following reports related to the USGS "Tight Gas Studies," were prepared and presented:

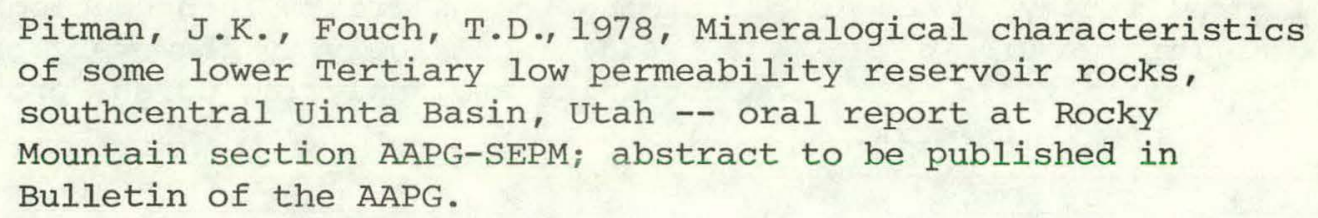

Work is continuing on the preparation of sub-surface data and allied studies.

Last months report, March 1978, showed a scanning electron microscope photograph of a core from the western Uinta Basin. The photo below shows the equipment used in that work (Fiqure 3-1).

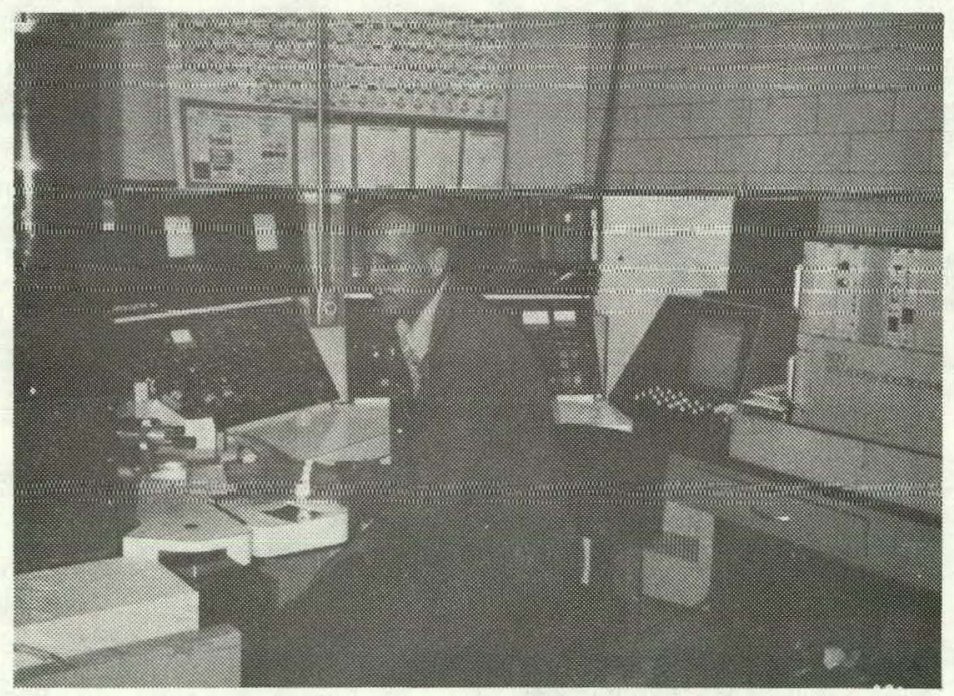

FIGURE 3-1 STEROSCAN SCANNING ELECTRON MICROSCOPE BEING USED TO STUDY CLAYS IN PORE-THROAT GEOMETRY 


\subsection{Coring Program}

The Core Acquisition, Logging and Production Testing Program was initiated with preliminary contacts with operators in the Northern Great Plains Province. This activity will continue during March, with a meeting scheduled to discuss locations with operators.

\subsection{Study of Basin Activities}

Drilling and testing activities in the four main study areas continue to be monitored. Figures 3-2 through 3-5 indicate the four areas and show recent wells of significance to thw Western Gas Sands Project. The following paragraphs give a brief account of the activity in each basin and detailed information on significant wells.

\subsubsection{Piceance Basin}

Rio Blanco Cuunly, Colorado, continues to be the area of significant drilling and testing activity in the Piceance Basin. Indian Wells oil Company has plans to drill four exploratory wells to test the Wasatch Formation in the Piceance Creek Gas Field. This new development, along with the Mobil Oil Company plans to drill eight Wasatch tests in the same vicinity, increases interest in central Rio Blanco County. These wells will be monitored closely for fracture treatments and evaluated for application to the WGSP.

Garfield County and the northern half of Mesa County also have drilling operations of importance. Adolph Coors has scheduled a 3,300 ft wildcat in Mesa County, their fourth in Section 24, TIOS, R97W. The area of interest is four miles west-northwest of the Plateau Gas Field which produces from Mesaverde, Cozzette and Corcoran. Sun oil has recently completed a well in northeastern Mesa County, flowing 1,836 MCFD from the Mesaverde, utilizing a sand-gel fracture treatment (Figure 3-2).

$$
\text { Well No. } 1
$$

Mesa County, Colorado

Sun Oil Company

1-5 Divide Creek

Section 20, T8S, R91W

Divide Creek Field

Mesaverde Production (3,510 - 3,906 ft gross)

Development gas well

Frac: 60,000 gal gel, $112,0001 \mathrm{~b}$ sand

IPF : 1,836 MCFD

Completion date: $2 / 16 / 78$ 


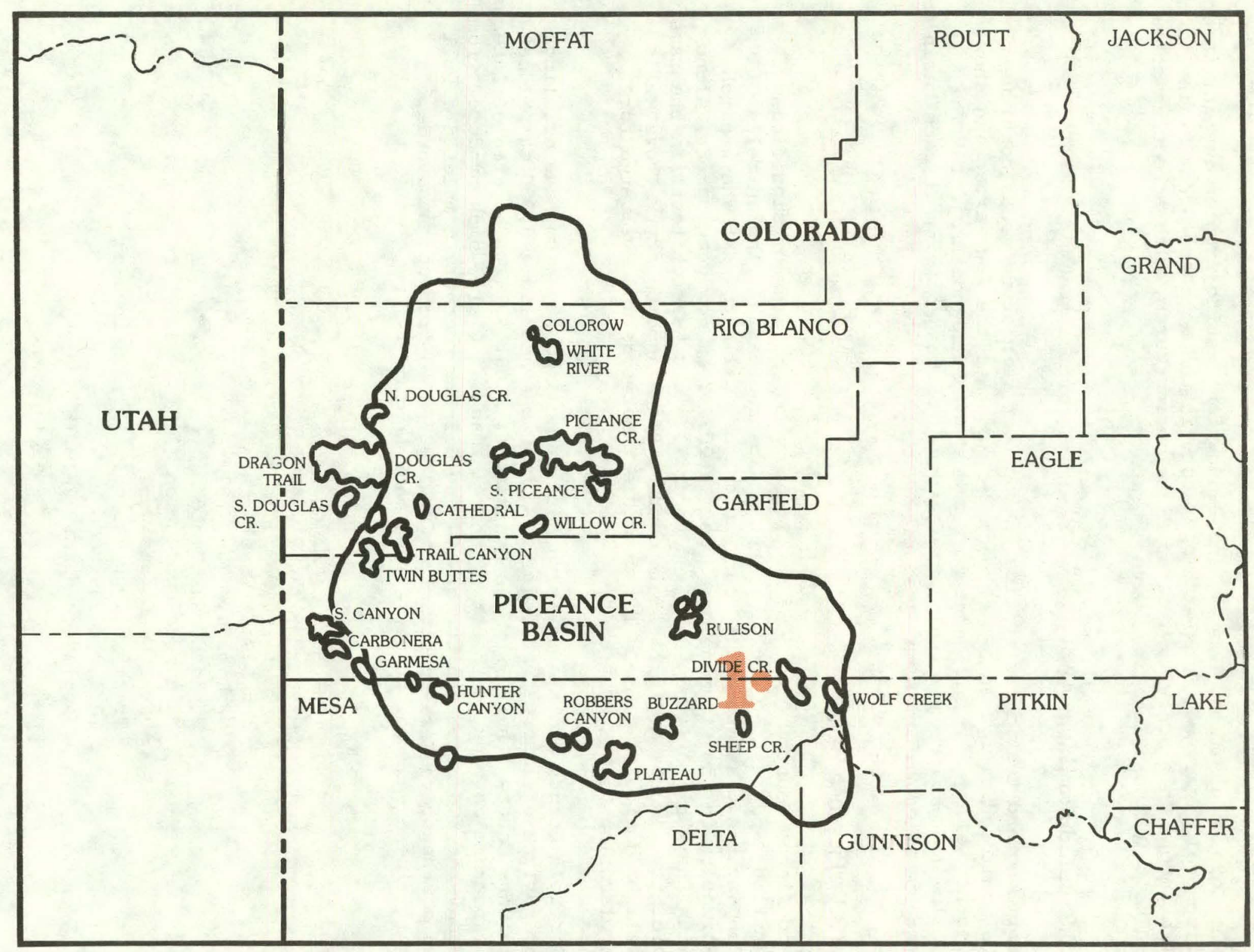

FIGURE 3-2 PICEANCE BASIN SHOWING WELLS OF INTEREST 
The major objectives in Garfield County are the Mancos and Dakota/Morrison Formations. The operators testing the Mancos are Tipperary Oil and Taiga Energy. Provident Resources and Palmer Oil and Gas are testing the Dakota and Morrison sands.

In Gunnison County, the southeastern portion of the basin, Ralston Oil and Gas has abandoned location on five wells scheduled to test the Mancos zone.

\subsubsection{Greater Green River Basin}

Drilling and testing activity in the Greater Green River Basin continues to be focused on the Mesaverde in Sweetwater County, Wyoming. However, there have been significant completions in the deeper formations. For example, Kenneth Luff has completed a well in the Nitchie Gulch Gas Field flowing 1,538 MCFD from Dakota sands. Just south of this completion, Northwest Exploration has a well with an IP of 237 MCFD from the $3 \mathrm{rd}$ Frontier using a sand-water fracture treatment. Smokey Oil is producing from the Mesaverde in the Wamsutter Arch Gas Field, in areas with a large amount of tight gas section (Figure 3-3).

Well No. 2

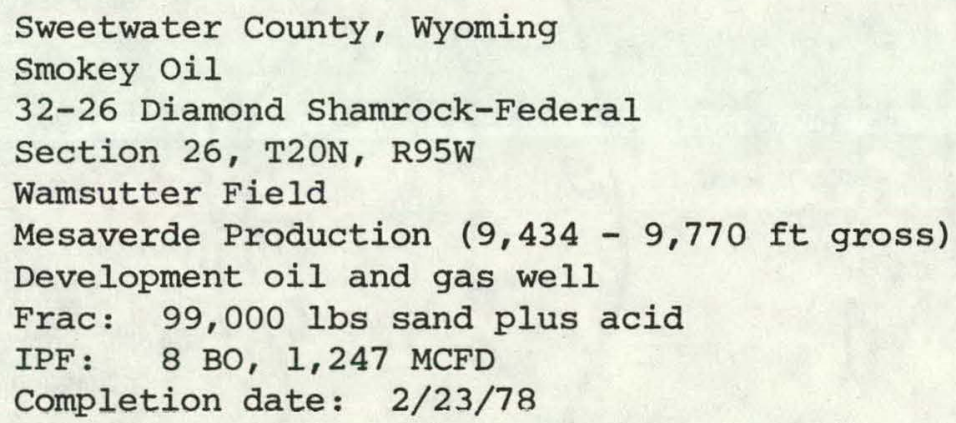

Carbon, Sublette and Lincoln Counties all have a significant number of ongoing Upper Cretaceous tests. The Mesaverde is the primary objective in Carbon County and the Frontier is most often tested in Lincoln and Sublette Counties. Amoco Production, Marathon Oil, David Company, Pacific Transmission Supply, Rainbow Resources and Belco Petroleum are some of the major operators in this very large area.

The southern-most portion of the basin, Sand Wash sub Basin, in Moffat County, Colorado, has had an increase in the number of completions during February. Rainbow Resources and Northwest Exploration have a well producing from the Lewis Formation. The Northwest Exploration well was sand/emulsion tractured. Kemmerer Coal Company's dual completion in the Lewis and Mesaverde section is flowing 1,287 MCFD after an oil and sand fracture treatment (Figure 3-3). 


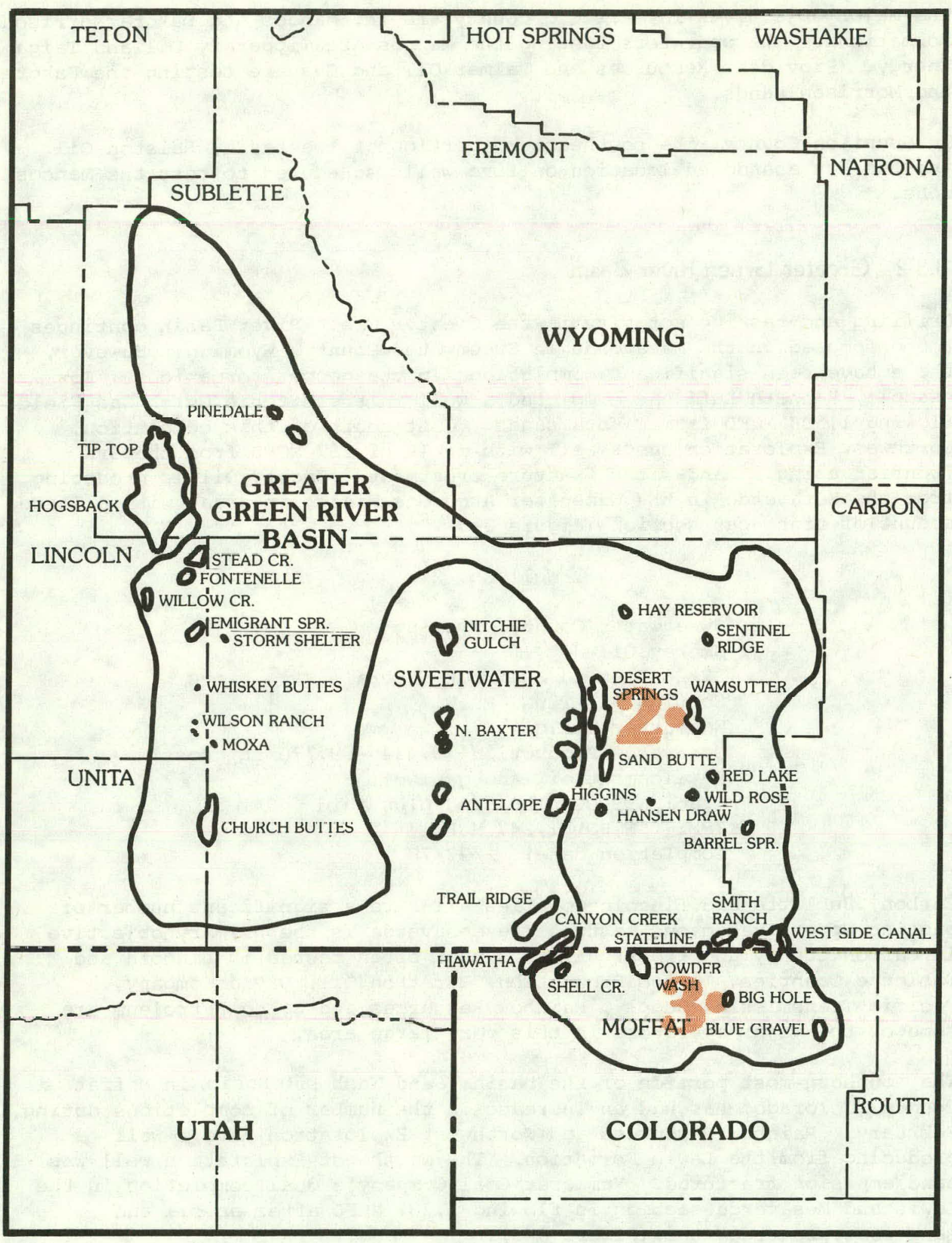

FIGURE 3-3 GREATER GREEN RIVER BASIN SHOWING WELLS OF INTEREST 
Well No. 3

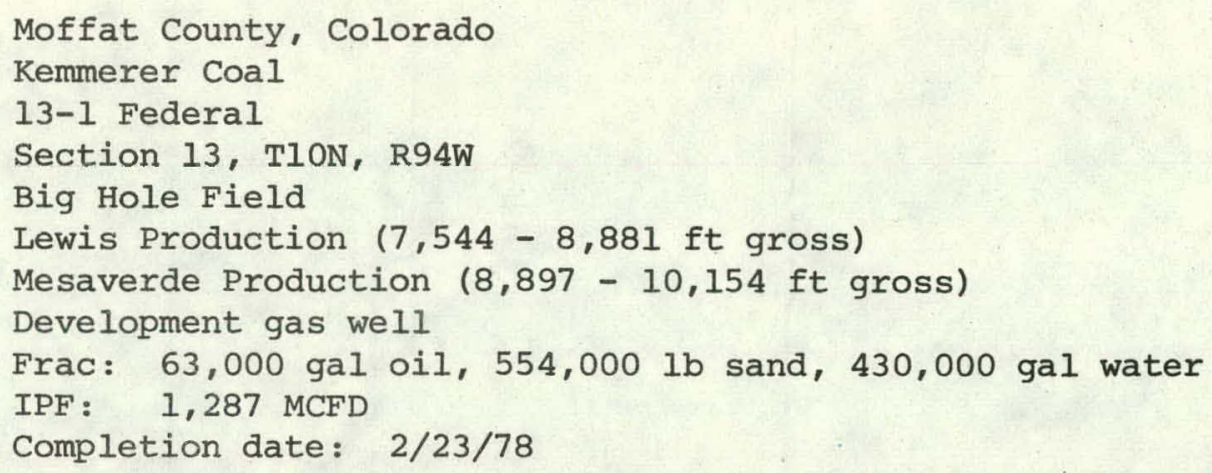

\title{
3.3.3 Uinta Basin
}

\begin{abstract}
Most of the activity in the Uinta Basin has been in the Natural Buttes and Chapita Wells Units of Uintah County, Utah. The major objectives are the tight Tertiary Wasatch and Upper Cretaceous Mesaverde Formations. Belco Petroleum has five new Wasatch tests in the area including a well producing 1,783 MCFD following a fracture treatment in the Wasatch (Figure 3-4).
\end{abstract}

Well No. 4

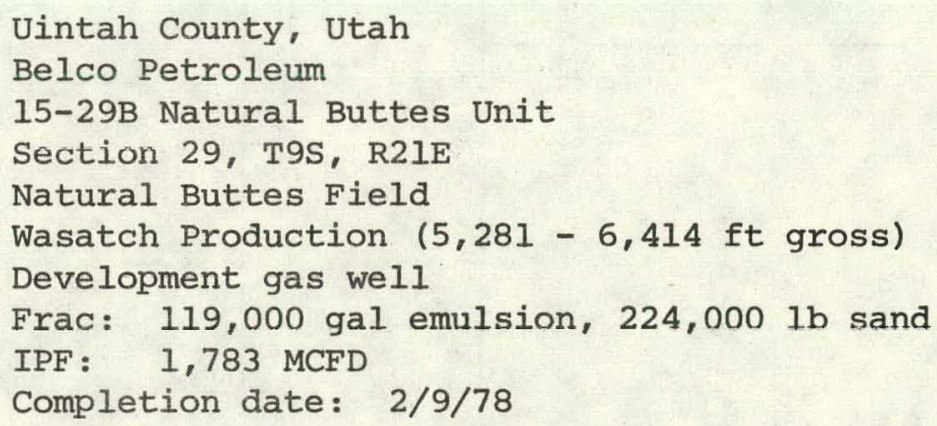

New developments this month include the staking of a Wasatch test in Peters' Point Field, Carbon County by Reserve Oil and Twin Arrow's scheduled 2,700 ft Mancos test in Uintah County. The projected Mancos test is located nearly six miles north-northeast of the Coyote Basin Field, which produces oil and gas from the Green River and Wasatch Formations. 


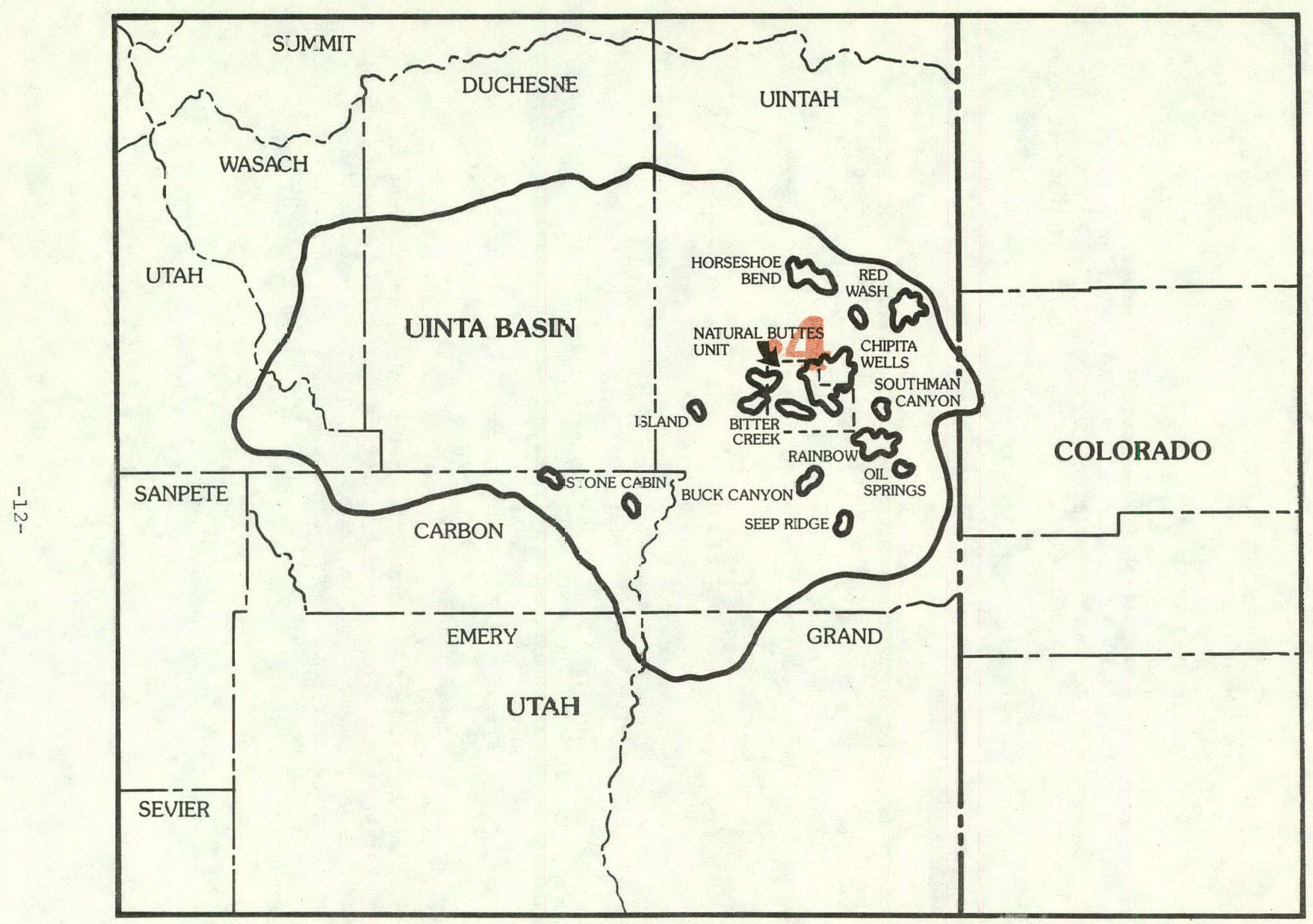

FIGURE 3-4 UIVTA BASIN SHOWING WELLS OF INTEREST 


\subsubsection{Northern Great Plains Province}

Most drilling activity in the Northern Great Plains Province ranges from the Sweetgrass Arch, Toole County, Montana to the west flank of Bowdoin Dome, Valley County, Montana. There is limited activity in the southern areas of the state, i.e. Fallon, Powder River, Carbon and Big Horn Counties. Marathon Oil has scheduled a 6,000 ft Ash Creek (Upper Cretaceous) test on the western edge of the Montana portion of the Powder River Basin.

Toole County, Montana will have another True Oil Company test in the Bow Island sands. The field opener flowed 60 MCFD from the untreated 2nd Bow Island. South of this play, Antares Oil and Century Oil and Gas are also interested in the Bow Island Formation and have announced two new outposts in a program to develop the Bow Island Gas Field they discovered in Pondera County last year.

Prospective shallow gas horizons in Hill, Blaine and Phillips Counties encompass the entire Upper Cretaceous sequence over most of the area: Judith River, Eagle, Niobrara, Carlile/Bowdoin and Greenhorn/Phillips sandstones and siltstones. J. Burns Brown has scheduled two 1,650 ft Eagle tests in Hill County. The new wells are located south of the Coal Coulee Gas Field which presently is producing from the Eagle. In northern Blaine County, John J. Lyon has abandoned four Eagle tests.

There has been an increase in activity in the North Bowdoin Field, Phillips County. Shenandoah Oil Corporation has drilled seven gas wells and participated in an eighth completion in the Loring Unit. The wells are presently shut-in awaiting a pipeline connection expected by mid-summer. The productive zones in the eight completed wells are the Bowdoin and Phillips sands. The average rate of flow was 2,21l MCFD. Just west of the Loring Gas Field, in an unnamed area, Midlands Gas Company has completed a 1,700 ft Phillips test for an IP of 769 MCFD from commingled Bowdoin and Phillips sands (Figure 3-5).

$$
\text { Well No. } 5
$$

Phillips County, Montana Midlands Gas Company 1160 Hellie Section 11, T36N, R3OE Unnamed field Bowdoin $(1,351-1,421$ ft gross $)$ Phillips $(1,535-1,564 \mathrm{ft}$ gross) production Development gas well

Frac: 100,000 $1 \mathrm{~b}$ sand, 33,000 gal water

IPF : $\quad 769$ MCFD

Completion date: $2 / 23 / 78$ 


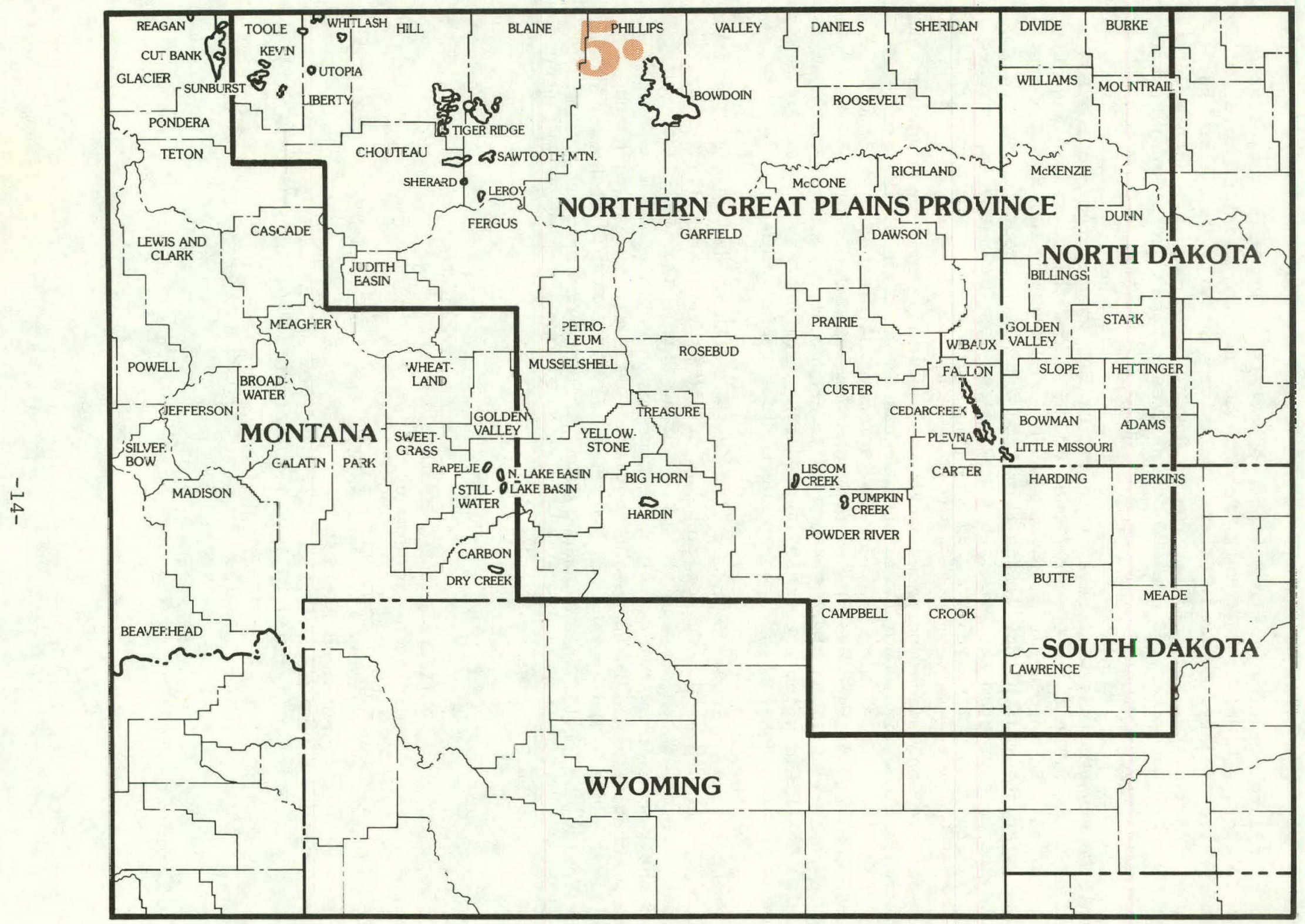

FIGURE 3-5 NORTHERN GREAT PLAINS PROVINCE SHOWING WELLS OF INTEREST 
The scheduling of five new wells by Jerry McCutchin Jr. is of importance to the development of the West Short Pine Hills Gas Field in Southwestern Harding County, South Dakota. All of the new wells are projected to the Shannon (Eagle) and development in this area could give South Dakota its first commercial gas field. 


\section{THIS PAGE}

\section{WAS INTENTIONALLY \\ LEFT BLANK}




\section{RESEARCH AND DEVELOPMENT BY ENERGY RESEARCH CENTERS AND NATIONAL LABORATORIES}

\subsection{Bartlesville Energy Research Center (BERC)}

\subsubsection{Improved Pressure Coring System}

Core retriever design work continued on the lower portion of the core barrel. Prospective ball valve and ball sub-designs are being prepared for evaluation and selection of the best approach. A meeting was held during the month with Christenson, U.S.A., personnel in Salt Lake City to review their pressure core barrel program. They are modifying and strengthening the Exxon barrel and will soon offer commercial service. They discussed an experiment that was performed in the early 1950's where a core barrel was filled with diesel fuel which was in turn, displaced by the core. Consequently, a clean core was recovered with no drilling mud contamination. This information is encouraging to the effort in reducing the flushing action while coring.

Coring fluid selection tests continued using Dow-Corning DC200 (60,000 Cs) silicone fluid to clean and lubricate a thin walled stratapax coring bit. Figure 4-1 shows the apparatus that was used. The bit was stationary and the rock was rotated at $40 \mathrm{rpm}$. The penetration rate was 0.005 inches per revolution with a coring fluid flow rate determined by the volume displacement of the core entering the barrel. Coring progressed smoothly to a depth of approximately six inches at which time the test was stopped so that the bit and core could be examined. Figure 4-2 shows the cored rock and extruded silicone fluid. Chip dispersion in the fluid was excellent and no chip removal problems were evident. In addition, the bottom of the hole appeared clean. Cooling was felt to be adequate at this low penetration rate because the bit was not hot to the touch upon removal.

Although this first test indicated that DC200 may be an acceptable coring fluid for this system, a more complex test has been planned for March 8 . The core barrel has been fitted with strain gages to enable the measurement of bit weight and torque as this information may help identify possible drilling problems that result from inadequate cleaning and cooling. New Stratapax cutters have been brazed to the bit which will allow a penetration rate of 0.050 inches per revolution. The fluid pressure inside the barrel will be recorded to help determine the flow characteristics of the fluid under coring conditions. These modifications are expected to make the laboratory coring test more representative of expected field conditions.

The viscosity of the coring fluid was measured from the ambient temperature of $25^{\circ} \mathrm{C}$ down to $-60^{\circ} \mathrm{C}$. The manufacturer's specifications of $60,000 \mathrm{cs}$ were correct within $\pm 20 \%$ down to $-20^{\circ}$, but then the viscosity increased at a higher rate than that stated. At $-60^{\circ}$ the viscosity was $800,000 \mathrm{cs}$. This high viscosity condition will occur only after the core has been transported to the surface and frozen in dry ice. A simple test is being designed to insure easy core removal under these conditions. 


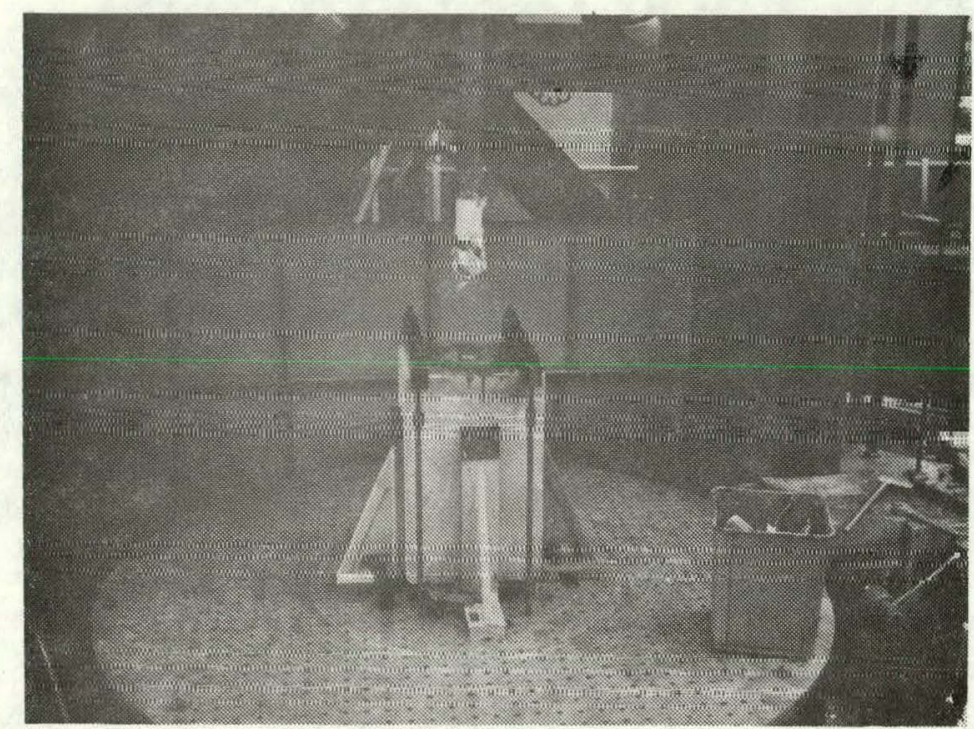

\section{FIGURE 4-1 APPARATUS FOR CORING TEST}

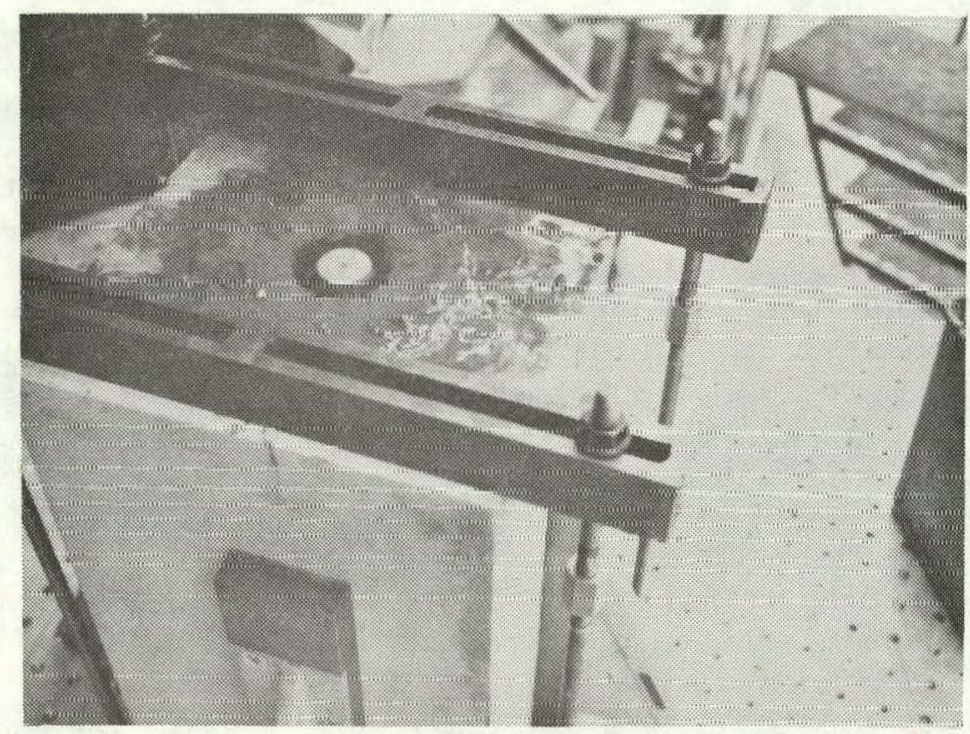

\section{FIGURE 4-2 ROCK CORED WITH DC200}

The latest Pressure Coring System bit design features a replaceable pilot section with seven matrix-mounted stratapax diamonds, a $45^{\circ}$ crown profile to minimize invasion, and internal and external gauge cutters. Maximum removal is 0.290 cubic centimeters per revolution at a depth of cut of 0.1 inch. This is a medium duty loading that should allow long life for the stud-mounted cutters. The number and location of mud ports is stil1 being studied. 
The ability of a Stratapax bit to drill sandstone at low penetration rates with marginal lubrication was found to be acceptable in the coring tests. Coring abilities at higher penetration rates will be evaluated during March.

Plans are being made for an industrial laboratory to perform measurements of formation core characteristics on core recovered from wells drilled during the remainder of $\mathrm{FY} 78$.

\subsubsection{Interface Conductivity Effects on Electric Logs}

Several tests of the surface area unit incorporating the new sample holder were completed. Practical methods for achieving a seal with wood's metal at liquid $\mathrm{N}_{2}$ temperature were developed. 'With proper sample treatment and a higher set pressure limit, the surface area unit appears to give the correct waveform.

The interpretation of the surface area measurement, when a pressure gradlent exlsts across the wafor, must also he determined. A suitable interpretation method should be developed in the following month.

Most of the laboratory equipment for the high pressure core resistivity test cell has been received and assembied. Initial tests with the assembly were started.

\subsubsection{Mapping and Contouring Formation Water Resistivity}

A large scale map has been prepared depicting the areal extent of $R_{W}$ information assembled for the Uinta Basin. Small scale maps delineating well locations and $\mathrm{R}_{\mathrm{w}}$ depths are being prepared. Initial data has shown significant variations in $R_{w}$ with both depth and areal extent.

\subsubsection{Logging Techniques and Interpretations}

A contract has been prepared and submitted to liexas A \& M University to study acoustic, density and neutron logs of western tight gas sands for development of improved understanding and interpretation techniques as applied to specific formations.

A survey and critique of techniques to measure water resistivity proposed by Sandia Laboratories is under consideration.

\subsubsection{Rock-Fluid Interaction}

A medium pressure liquid-injection apparatus has been assembled and tested in the laboratory. Additional high pressure components are on order or are being built which will enable the apparatus to be used at pressures up to 8,000 psi. 
An experiment was conducted with the medium pressure liquid injection apparatus. A $2 \%$ sodium chloride solution was pumped past the face of a 0.5 inch thick, 1.5 inch diameter core at an injection pressure of 3,600 psi and a representative flowrate. After about two hours, brine began to percolate through the core very slowly. Only about 1 milliliter of fluid was collected before the experiment had to be discontinued. The particle size distribution of this sample was measured and a number count indicated approximately 15,000 particles per $\mathrm{ml}$ with a mean of 2.0 microns had passed through with the liquid.

\subsection{Lawrence Livermore Laboratory (LLL)}

\subsubsection{Theoretical Analysis}

Tle two dimensionä 1 model was applied to calculate several prohlems with layered geometry, where the permeabilities as well as the mechanical properties across the interfare were variod. In these inlulationo, the tracture was symmetrically located across the interface and perpendicular to it.

Preliminary indications from these calculations include: 1) that for permeability variations from one side of the interface to the other, the side with the highest permeability showed the highest rate of the decrease of the Mode I stress intensification factor $\left(\mathrm{K}_{\mathrm{I}}\right)$. This indication was expected because when the equation $\tau=\mathrm{KT} / \mathrm{SL}^{2}$ is applied to non-dimensionalyze the time and crack lengths, the Mode I stress intensification factor for crack tip on the higher permeability side should show a factor time rate decrease; and 2) that for changes in Young's modulus across the interface, the calculations indicated that $\mathrm{K}_{I}$ on the side with the higher modulus was significantly increased by the presence of the lower modulus material on the nther sire. On tho oide with lưwer uudulus, ${ }^{\prime} I$ was stgnificantly reduced from what was calculated for a pressurized crack in a homogeneous medium. In these calculations, it was assumed that no slippage could occur across the interface.

Two calculations were made to obtain estimates of how changes in elastic parameters in a layer affect surface response near a vertical hydrofracture. The results of these calculations were publishcd as part of UCRL-80360, and also as a preprint for presentation at the lith U.S. Symposium on Rock Mechanics at Lake Tahoe, in May 1978.

Work is continuing to reduce boundary effects in the numerical grid. 'the variation in surface response, above a vertical hydrofracture, due to changes in grid size, is being analyzed. In order to verify that this response is converging to the correct result, an analytic solution is needed. Some dislocation solutions exist for the restricted case where no layers are present but they have a serious defect: The form of the dislocation is a constant displacement on the hydrofracture face instead 
of the more reasonable constant pressure boundary condition that is used in the finite element model. LLL is currently trying to obtain at least an analytic estimate to compare with the numerical results using this dislocation method.

The layer effects near a vertical hydrofracture are studied with different cases corresponding to different elastic parameters describing the layer. The layer is positioned above the hydrofracture as shown in the sketch at the top of Figure 4-3, The hydrofracture height is $\mathrm{h}$ and the depth of the layer is $\ell$. The sketch is drawn to scale, i.e., $\ell=h=d / 3$. The layer is distinguished by the hashed lines. Two cases are considered for this geometry.

Figure 4-3 has surface slope as a function of distance along the surface, cross sectional distortion contours, and dilation contours. If the problem setup sketch is bisected along the $y$ axis, then the six plots in Figure 4-3 correspond to the right half of the sketch. Half plane symmetry applies so the left half is implied. Distance is given in terms of $d$, the distance from the top of the hydrofracture to the surface. In plots $A, B$, and $C$, the layer identified by the subscript 1, has Young's modulus $\left(E_{1}\right)$ equal to $10 \mathrm{GPa}$ and a Poisson's ratio $\left(\nu_{1}\right)$ of 0.35 . The surrounding material has the same Young's modulus but a different Poisson's ratio $\left(v_{2}\right)-0.20$. In plots $\mathrm{D}, \mathrm{E}$, and $\mathrm{F}$, the layer has $\mathrm{E}_{1}=10 \mathrm{GPa}, \mathrm{E}_{2}=20$ $G P a$, and $\nu_{1}=\nu_{2}=0.2$. The line plots, plots $A$ and $D$, are a measure of the tilt along the surface. These tilt plots for the two cases differ slightly: the maximum peak is greater for the second case while the peak is nearer the center for the first case.

Plots $B$ and $E$ are dilatation plots, $\left(\varepsilon_{1}+\varepsilon_{2}\right)$, the sum of the principal strains, for the two cases while plots $C$ and $F$ are distortional plots $\left|\varepsilon_{1}-\varepsilon_{2}\right|$, the difference of the principal strains. The strain contours near the hydrofracture were eliminated from the plots because they were indistinguishable. This results in the voids at the lower left side of the four plots. Perturbations in the strains due to the layer are evident in the four plots. The layer perturbation, however, appears to be stronger for the first case.

Work contined on the modeling of the post fracture pressure drawdown and buildup test of Zone 1 of the Piceance Creek Unit Well F31-13G. As previously reported, a "simple" model whose parameters are formation properties, fracture length, and wellbore/fracture storage is unable to adequately model the test data. The use of one additional parameter, however, resulted in a quite reasonable fit to the test data. This parameter is a flow resistance at the formation-fracture interface, and may be physically related to fracture fluid formation damage such as plugging and clay swelling. In this sense it is analogous to the "classical" skin effect and may be expressed in the same manner as the "skin factor," a dimensionless multiplier of $\frac{9 \mu}{2 \pi k}$ which gives the (flowing) pressure drop at the interface: The slbject well was produced 


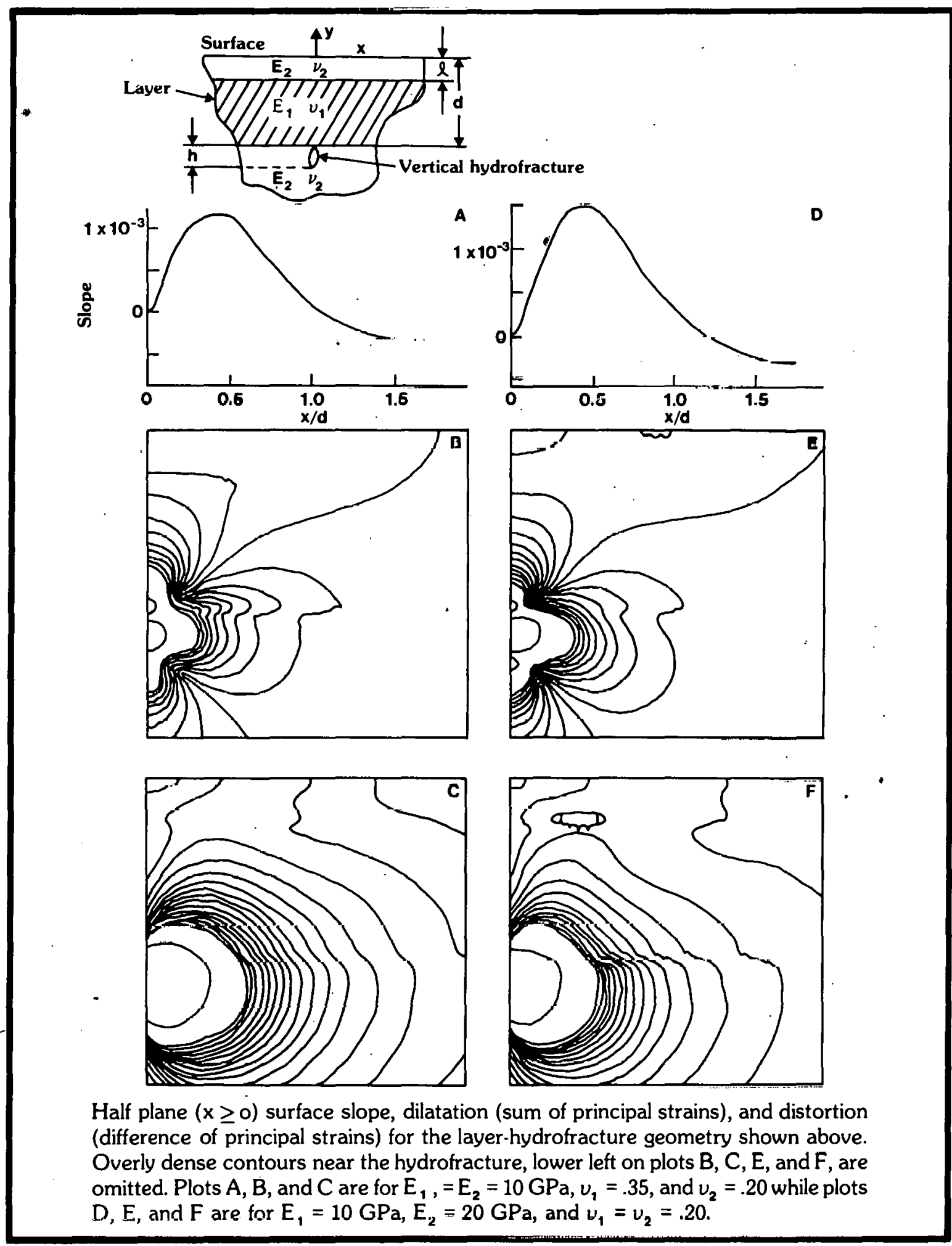

FIGURE 4-3 LAYER EFFECTS NEAR A VERTICAL HYDROFRACTURE 
for 7 days at a flow rate of 800,000 SCFD and was then shut in for pressure buildup measurements. The model parameters that gave a reasonable fit are:

$\begin{array}{rl}\text { Formation pressure } & .4,650 \mathrm{psi} \\ \mathrm{kh} & 1.12 \mathrm{md}-\mathrm{ft} \\ {\phi \mathrm{L}^{2} \mathrm{~h}}^{2} & 10,000 \mathrm{ft}^{3} \\ \text { Well and fracture storage } & 3,350 \mathrm{ft}^{3} \\ \text { Damage factor } & 1\end{array}$

In order to separate the individual variables, some additional knowledge or assumptions must be applied. For example, the assumption of a hydrocarbon porosity $(\phi)$ of 28 and a net pay height (h) of $50 \mathrm{ft}$, (the gross interval was $131 \mathrm{ft}$ ), leads to a permeability (k) of $22.4 \mathrm{\mu d}$ and a fracture wing length (L) of $100 \mathrm{ft}$.

Figure 4-4 shows the buildup data plotted as pressure vs. Horner time along with two model calculations, the lower curve with flow resistance, the upper curve without.

\subsubsection{Laboratory Experiments}

During the month, work continued on the study of crack growth across unbonded loaded interfaces in limestone and sandstone. It was found, as shown by Figure 4-5, that at the particular load of this experiment, the crack crossed an interface with a rough finish, but did not cross an interface with a smooth finish. Experiments of this type are being performed with all sandstone blocks, all limestone blocks and various combinations of both.

\subsubsection{Environmental Assessment}

Environmental assessment reports for Enhanced Gas Recovery (EGR) projects are in preparation.

In the EGR program in the Western Gas Sands Project, activity focused on the cyclic dry gas injection project being undertaken by colorado Interstate Gas (CIG) in the Wattenberg Field, Weld county, Colorado. A visit was made to the project site in December, 1977 and due to the limited nature of the experiment, and the use of two previously drilled wells, no environmental problems are anticipated. The environmental assessment report will be completed upon receipt of information regarding the specifications of the compressor to be used at the site. 


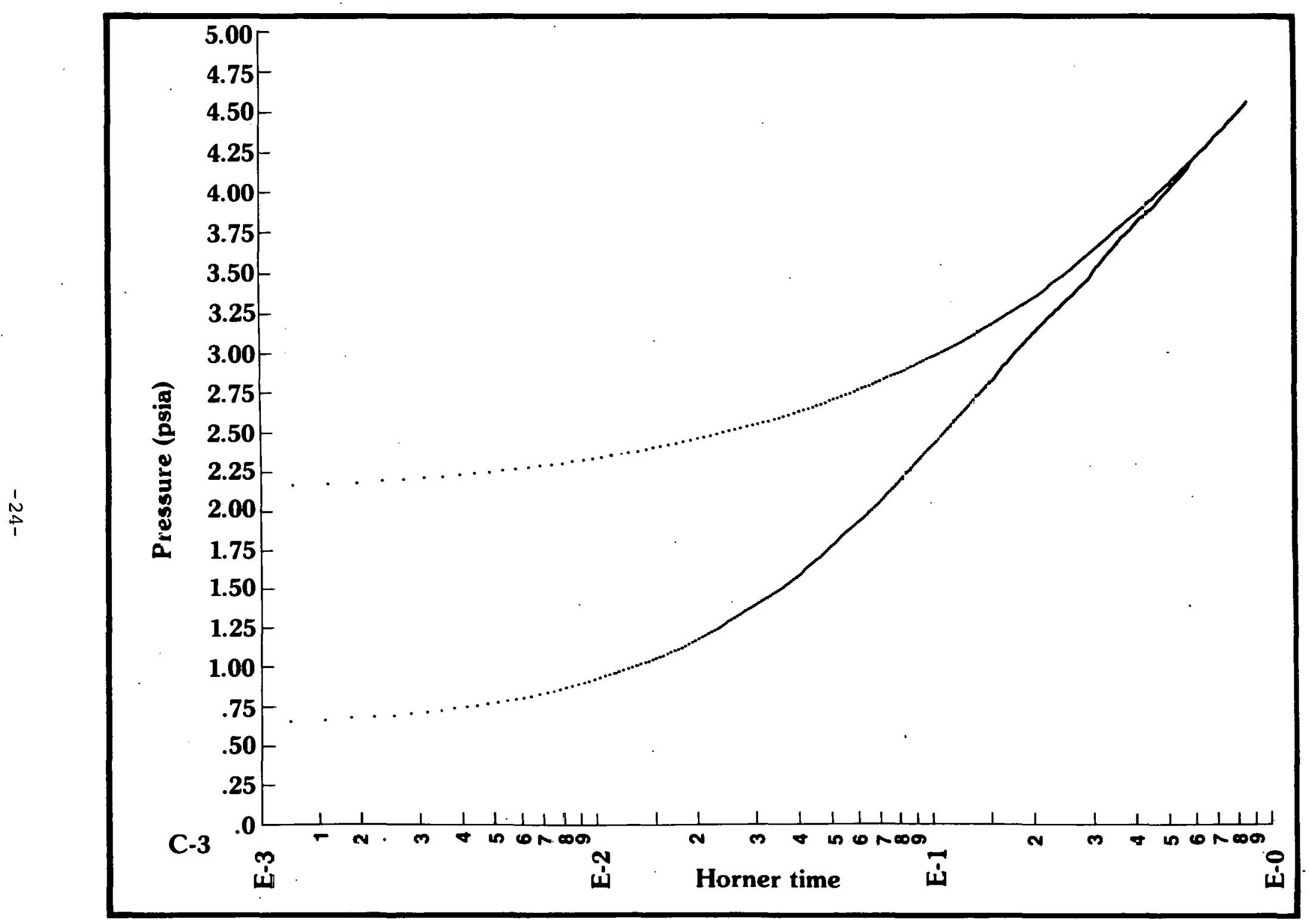

FIGURE 4-4 MODEL PRESSURE BUILD-UP 


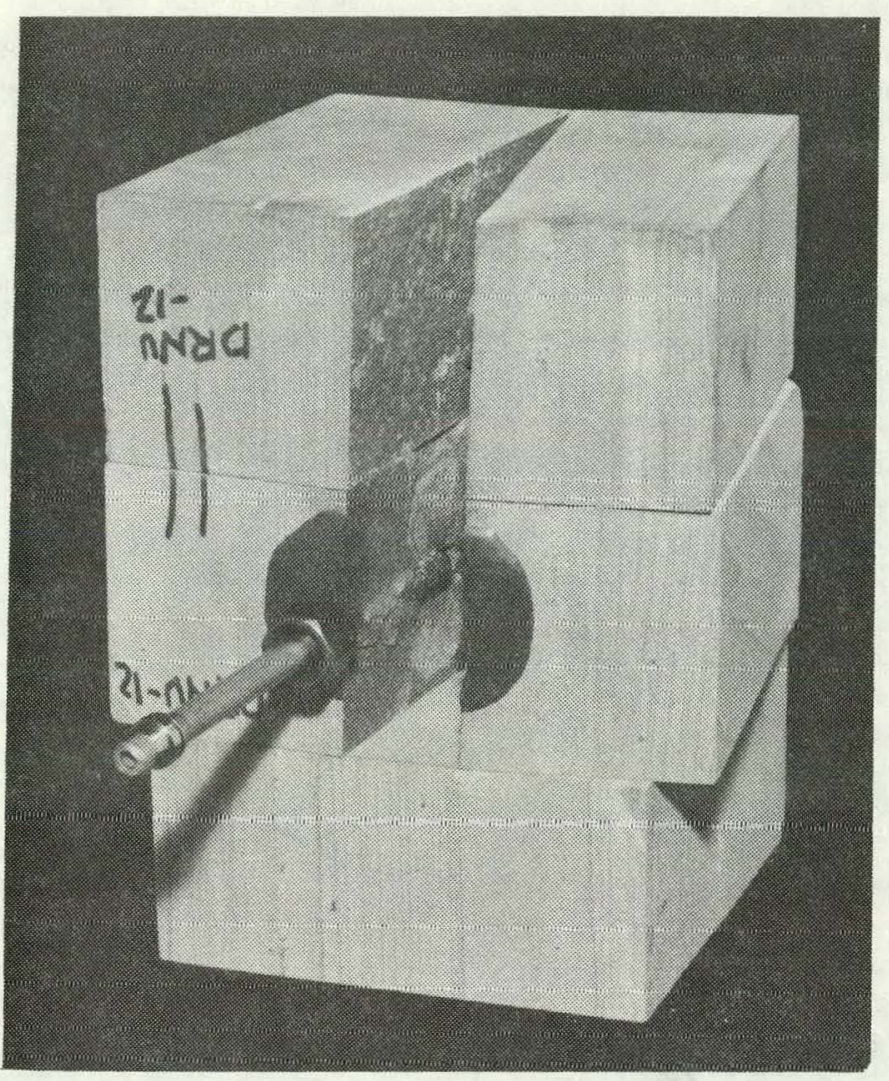

\section{FIGURE 4-5 HYDRAULICALLY DRIVEN CRACK NEAR UNBONDED INTERFACES IN NUGGET SANDSTONE}

\subsection{Sandia Laboratories}

\subsubsection{Hydraulic Fracture Mapping}

Sandia Laboratories, USGS, and Texas A \& M University are participating with Amoco. in a series of fracturing experiments in the Wattenberg Field northeast of Denver, Colorado.

Preliminary analysis of the seismic signals received from the Horst breakdown pumping (first wattenberg experiment) with the borehole seismic package clamped in the open hole section has been continuing. High speed playbacks have been made of signals during five quiet periods during the pumping. These quiet periods are immediately after breakdown, after each of the three 5,000 gal pumping stages, and during the middle of flowback during a shut in. Many of the signals received appeared to be of a hiqh frequency impulse type which is exciting the geophones and their mount into resonance at its natural frequency. There are, in addition to these resonant mount signals, two other apparent classes of signals whose origins are not understood. These signals will be further analyzed in the upcoming months. 
The second Wattenberg experiment was conducted on February 15 in a well located about $1 / 2$ mile east of the Horst well, which was fractured at the end of January. This well, Jeffers Well No. 1, was to be the experiment on which Amoco placed their downhole TV camera during the breakdown phase. However, the camera developed a water leak and this portion of the experiment was abandoned. Tubing was then hung in the well and Sandia attempted to use a downhole current probe for the electrical potential measurements. Electronic problems in the current generator precluded the use of the downhole current probe, and it was removed.

The Hewlett Packard (HP) gauge was inserted into the tubing to approximately $50 \mathrm{ft}$ above the bottom where it recorded pressure during the main fracture on February 15. An excellent pressure record was obtained for the majority of the pumping; however, at very high pump rates, the pressure gauge was intermittant. Several rate changes were made in the pumping program and these chanqes in bottom hole pressure can be seen nn the pressure records. A digitized copy of this pressure record is included as Figure 4-6.

The third and final Wattenberg experiment is scheduled for march 7 and will be conducted in the Carlson Well approximately 3 miles to the southwest of the Jeffers Well No. 1. Tentative plans have been made to use the borehole seismic package after the main pumping in the third experiment. The package will be located in the lubricator above the frac fluid insertion point during the main pumping and following shut in will be lowered and clamped in place.

\subsubsection{Mineback Stimulation Test Program}

The mineback of the Hole \#6 "Interface Experiment" was still suspended in February. The third exploratory corehole (EV6\#3) was drilled $+7^{\circ}$ up into the welded tuff at $\$ 37.5 \%$ as shown in Figure $4-7$. A fracture, apparently the green grout, has been intersected at $142.5 \mathrm{ft}$ in this corehole and in the densest part of the welded tuff. The plane of the fracture is at approximately $80^{\circ}$ to the core axis. Because of the exploratory corehole results, the mineback plan has been revised. The mineback will now proceed $\mathrm{S} 25^{\circ} \mathrm{W}$ for about $100 \mathrm{ft}$ and then turn to $555^{\circ} \mathrm{W}$ and proceed toward Hole \#6. This is the apparent direction at which the lower fracture propagated and the mineback should intersect this fracture at the nearest location. The mineback route will also hug the interface proceeding through the ash fall tuff. (Mining through the welded tuff is much more difficult and slower than through the ash fall tuff.) This will provide information about the fracture behavior at the interface.

Further material property data from the UEl2gl0\#6 cores have been received. The density and porosity for 8 samples are shown in Table 4-1. The dense, welded tuff at 1,323 ft stands out with its high density and low porosity. The ash fall tuff at 1,354 and 1,363 ft has low densities and high porosities. 


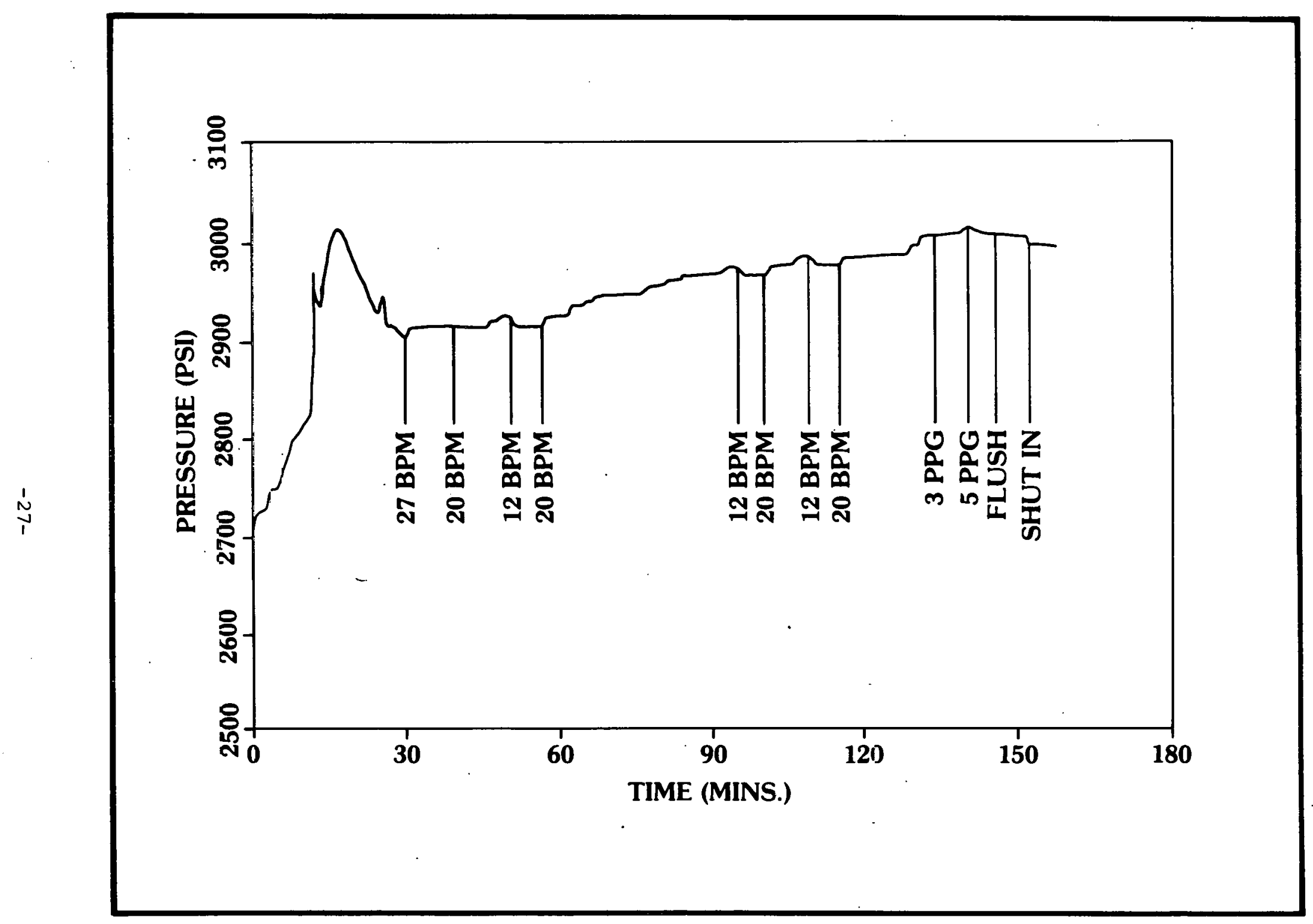

FIGURE 4-6 DOWNHOLE PRESSURE JEFFERS WELL NO. 1 


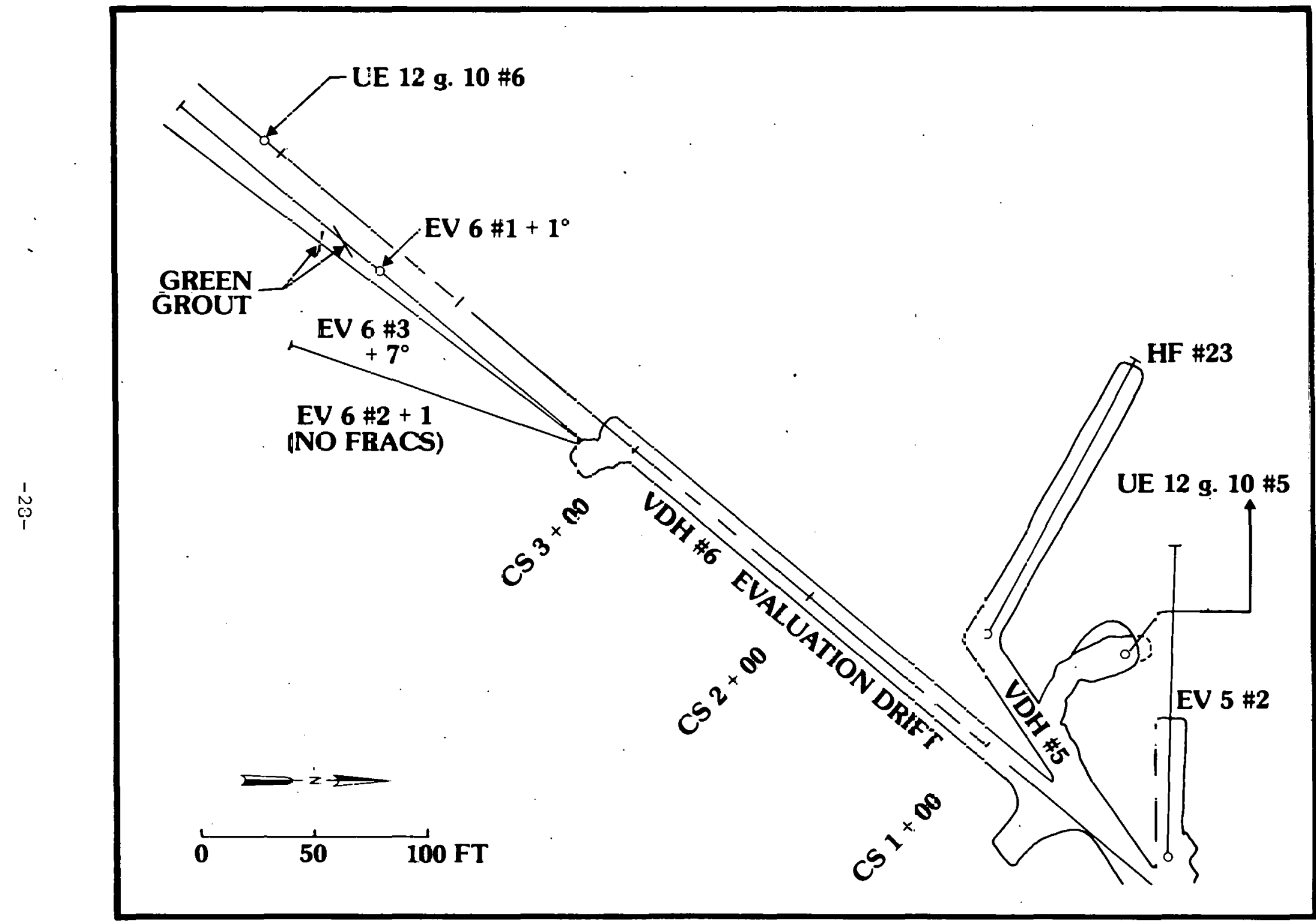

FIGURE 4-7 CLRRENT MINEBACK ACTIUITIES, G TUNNEL, NEVADA TEST SITE 
TABLE 4-1 DENSITY AND POROSITY OF UE 12 g. 10 \#6 CORE SAMPLES

\begin{tabular}{|c|c|c|c|c|c|}
\hline \multirow{2}{*}{$\begin{array}{l}\text { Depth } \\
\text { (ft) }\end{array}$} & \multirow[b]{2}{*}{ Type } & \multicolumn{2}{|c|}{$\begin{array}{c}\text { Bulk Density } \\
(\mathrm{gm} / \mathrm{cc})\end{array}$} & \multirow{2}{*}{$\begin{array}{c}\text { Grain } \\
\text { Density } \\
(\mathrm{gm} / \mathrm{cc})\end{array}$} & \multirow{2}{*}{$\begin{array}{c}\text { Porosity } \\
\%\end{array}$} \\
\hline & & Natural & Dry & & \\
\hline 1297 & Ashfall & 1.95 & 1.62 & 2.49 & 35.0 \\
\hline 1305 & Transition & 2.12 & 1.87 & 2.62 & 28.7 \\
\hline 1313 & Transition & 1.92 & 1.57 & 2.63 & 40.3 \\
\hline 1323 & Densely Welded & 2.42 & 2.31 & 2.65 & 12.8 \\
\hline 1339 & Lower Transition & 2.18 & 1.95 & 2.63 & 25.7 \\
\hline 1343 & Lower Transition & $\dot{2} .14$ & $1 . y^{\prime \prime}$ & $2.4 \%$ & 20.1 \\
\hline 1354 & Ashfall & 1.67 & 1.23 & 2.42 & 49.2 \\
\hline 1363 & Ashfall & 1.68 & 1.24 & 2.42 & 48.6 \\
\hline
\end{tabular}

Mineback on HF \#23 has been completed and EV5\#2 has been partially completed. These are minebacks of mini-hydraulic fractures performed to obtain in situ stresses in the vicinity of the Hole \#5 "Staged Proppant Experiment." The mineback of $\mathrm{HF} \# 23$ revealed 7 hydraulic fractures that were propagated on either side of two faults that may have influenced the Hole \#5 experiment. The mini-hydraulic fractures are very complex and have propagated into the faults and bedding planes. Preliminary data, however, does show a different fracture orientation on opposite sides of the faults. The EV5\#2 mineback has revealed 5 of the 9 minifracs. These fracs were also complex and will be further examined when the EV5\#2 mineback is complete.

A hydraulic fracturing tensile strength experiment was performed in conjunction with the minifrac in situ stress experiments. This test is performed by cutting three sides of a drift face in an attempt to relieve the in situ stresses on a large block of rocks. Short holes are drilled into the resulting block and then a zone is fractured. The breakdown pressure is equal to' an in situ tensile strength when the stresses are relieved. Preliminary data of the first tests show the tensile strengths for the ash fall tuff to be in the range of $300-600 \mathrm{psi}$. 


\subsection{U.S. Geological Survey (USGS) Borehole Gravity Meter .}

Instrumentation and testing are continuing, but work is progressing slower than expected.

\subsection{U.S. Geological Survey/Menlo Park-Tiltmeter}

(no report received) 


\section{FIELD TESTS AND DEMONSTRATIONS}

\subsection{Background}

The Uinta Basin in Utah and the Piceance Basin in colorado are the sites of three active MHF projects in which Upper Cretaceous tight gas-bearing sands are being stimulated. The following organizations and wells are involved:

Gas Producing Enterprises. (GPE), Natural Buttes Unit Wells No. $14,18,19,20,21$ and 22 .

Mobil Research and Development, Well No. F-31-13G

Rio Blanco Natural Gas Company, Well No. 498-4-1

The CER Corporation RB-MHF 3 is on inactive status pending satisfactory contractual arrangements to perform additional tests; and for final disposition of the well.

Colorado Interstate Gas Company has been awarded a contract to determine if productivity in low permeability reservoirs can be improved by reducing the interstitial water saturation. They intend to conduct experiments in two wells, the Sprague No. 1 and Miller-No. 1, completed in the Dakota $J$ Formation in the Wattenberg Field, north of Denver, Colorado.

Table 5-1 summarizes both completed and active Western Gas Sands Project MHF Projects. Progress of the active MHF projects is described in the following sections. 
TABLE 5-1 MHF CONTRACT LOCATIONS AND FRAC DATA

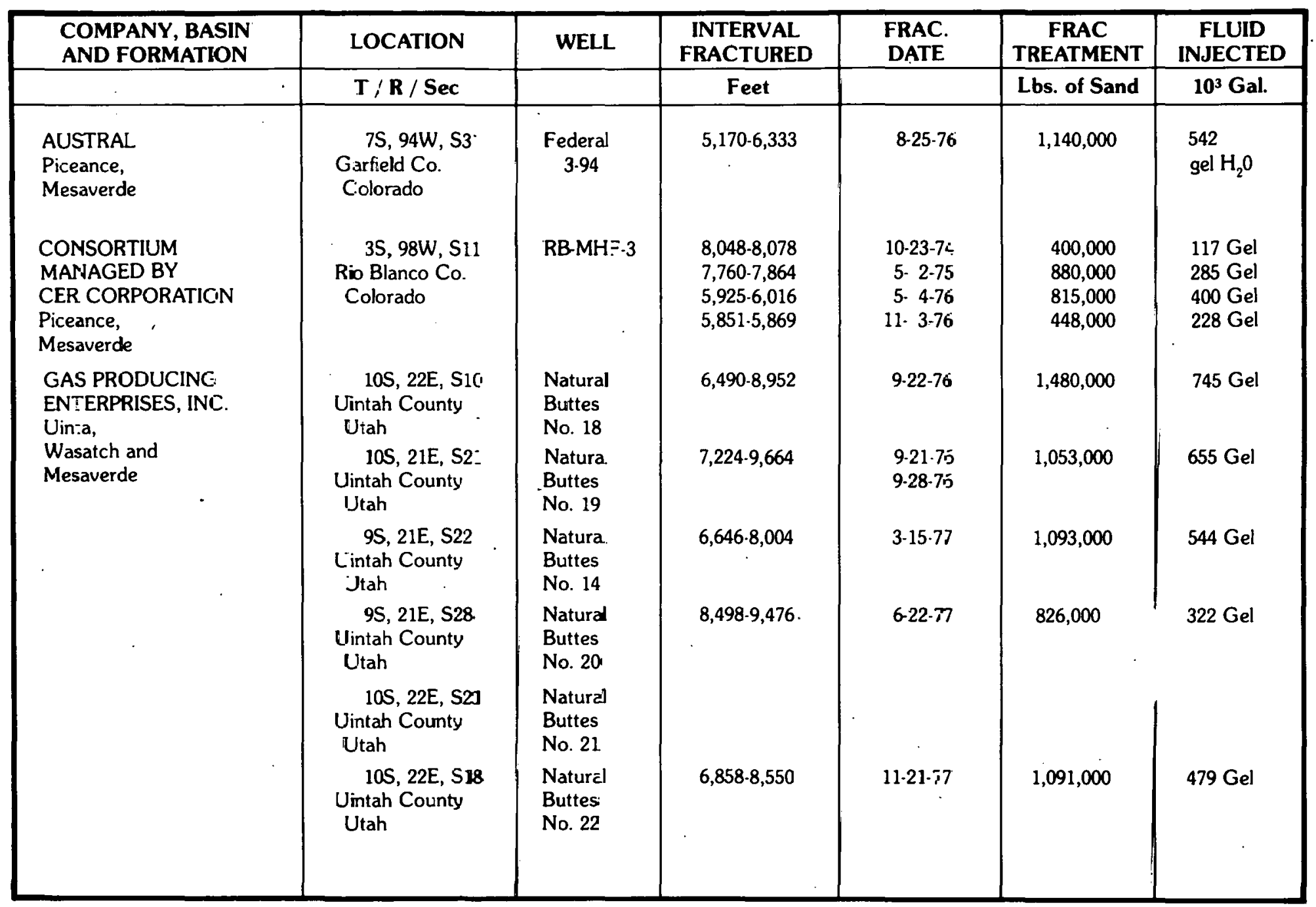




\section{TABLE 5-1 CONTINUED}

\begin{tabular}{|c|c|c|c|c|c|c|}
\hline $\begin{array}{l}\text { COMPANY, BASIN } \\
\text { AND FORMATION }\end{array}$ & LOCATION & WELL & $\begin{array}{l}\text { INTERVAL } \\
\text { FRACTURED }\end{array}$ & $\begin{array}{l}\text { FRAC. } \\
\text { DATE }\end{array}$ & $\begin{array}{c}\text { FRAC } \\
\text { TREATMENT }\end{array}$ & $\begin{array}{c}\text { FLUID } \\
\text { INJECTED }\end{array}$ \\
\hline & $\mathrm{T} / \mathrm{R} / \mathrm{Sec}$ & & Feet & & Lbs. of Sand & $10^{3} \mathrm{Gal}$. \\
\hline $\begin{array}{l}\text { DALLAS PRODUCTION } \\
\text { Fort Worth, } \\
\text { Bend Cong. }\end{array}$ & $\begin{array}{l}\text { Ben D. Smith } \\
\text { Survey A-779 } \\
\text { Wise County, } \\
\text { Texas }\end{array}$ & $\begin{array}{l}\text { Ferguson } \\
\text { A-1 }\end{array}$ & $5,957-6,794$ & $9-10-76$ & 506,000 & $\begin{array}{l}139 \text { Foam } \\
198 \text { Emul. }\end{array}$ \\
\hline $\begin{array}{l}\text { EL PASO NATL. GAS } \\
\text { Northern Green } \\
\text { River, } \\
\text { Fort Union }\end{array}$ & $\begin{array}{l}30 \mathrm{~N}, 108 \mathrm{~W}, \mathrm{~S} 5 \\
\text { Sublette Co. } \\
\text { Wyoming }\end{array}$ & $\begin{array}{l}\text { Pinedale } \\
\text { Unit } \\
\text { No. } 5\end{array}$ & $\begin{array}{l}10,950-11,180 \\
10,120-10,790\end{array}$ & $\begin{array}{l}\text { 7. } 2-75 \\
10-20-75\end{array}$ & $\begin{array}{r}518,000 \\
1,422,000\end{array}$ & $\begin{array}{l}183 \text { Emul. } \\
8 \mathrm{Gel} \\
459 \mathrm{Gel}\end{array}$ \\
\hline $\begin{array}{l}\text { MOBIL } \\
\text { Piceance } \\
\text { Mesaverde }\end{array}$ & $\begin{array}{l}\text { 2S. } 97 \mathrm{~W}, \mathrm{~S} 13 \\
\text { Rio Blanco Co. } \\
\text { Colo:ado }\end{array}$ & F-31-13G & $\begin{array}{r}10,549-10,680 \\
9,392-9,534\end{array}$ & $\begin{array}{l}6-22-77 \\
8-24-77\end{array}$ & $\begin{array}{l}580,000 \\
600,000\end{array}$ & $\begin{array}{l}316 \mathrm{Gel} \\
260 \mathrm{Gel}\end{array}$ \\
\hline $\begin{array}{l}\text { PACIFIC } \\
\text { TRANSMISSION } \\
\text { Uinta, } \\
\text { Mesaverde }\end{array}$ & $\begin{array}{l}\text { 8S, } 23 \mathrm{E}, \mathrm{S} 25 \\
\text { Uintah County } \\
\text { Utah }\end{array}$ & Fed $23-25$ & $\mathrm{NOF}$ & CS PERF & MED & \\
\hline $\begin{array}{l}\text { RIO BLANCO } \\
\text { Piceance, } \\
\text { Mesaverde }\end{array}$ & $\begin{array}{l}\text { 4S, } 98 \mathrm{~W}, \mathrm{~S} 4 \\
\text { Rio B anco Co. } \\
\text { Colorado }\end{array}$ & Fed 498-4-1 & $\begin{array}{l}6,150-6,312 \\
5,376-5,960\end{array}$ & $\begin{array}{l}10-22-76 \\
11-30-77\end{array}$ & $\begin{array}{l}776,000 \\
275,500\end{array}$ & $\begin{array}{l}276 \mathrm{Gel} \\
164 \mathrm{Gel}\end{array}$ \\
\hline $\begin{array}{l}\text { WESTCO } \\
\text { Uinta, } \\
\text { Mesaverde }\end{array}$ & $\begin{array}{l}10 \mathrm{~S}, 19 \mathrm{E}, \mathrm{S} 34 \\
\text { Uintai County } \\
\text { Utah. }\end{array}$ & $\begin{array}{l}\text { Home Fed. } \\
\text { No. } 1\end{array}$ & $\begin{array}{r}7,826-9,437 \\
10,014-10,202\end{array}$ & $\begin{array}{l}12-21-76 \\
10-1-76\end{array}$ & $\begin{array}{l}500,000 \\
600,000\end{array}$ & $\begin{array}{l}412 \mathrm{Gel} \\
248 \mathrm{Gel}\end{array}$ \\
\hline
\end{tabular}


CER Corp.

Las Vegas, Nevada

Interagency Agreement Date:

Project Cost (estimated):

Principal Investigator:

Technical Advisor for DOE:
Status: Awaiting Advisory Committee Decision

June 19, 1974

DOE

Industry

$1,630,000$

Total

$\$ 3,605,000$

G. R. Luetkehans

Charles H. Atkinson, Bartlesville Energy

Research Center

\section{OBJECTIVE}

This stimulation experiment is being conducted in low-permeability, massive gasbearing sandstone reservoirs in the Piceance Basin in western Colorado, to test advanced hydraulic fracturing technology where it has not been possible to obtain commercial production rates. This test is located about 1 mile from the 1973 Rio Blanco nuclear stimulation site to permit comparison of nuclear and hydraulic fracturing techniques in this area.

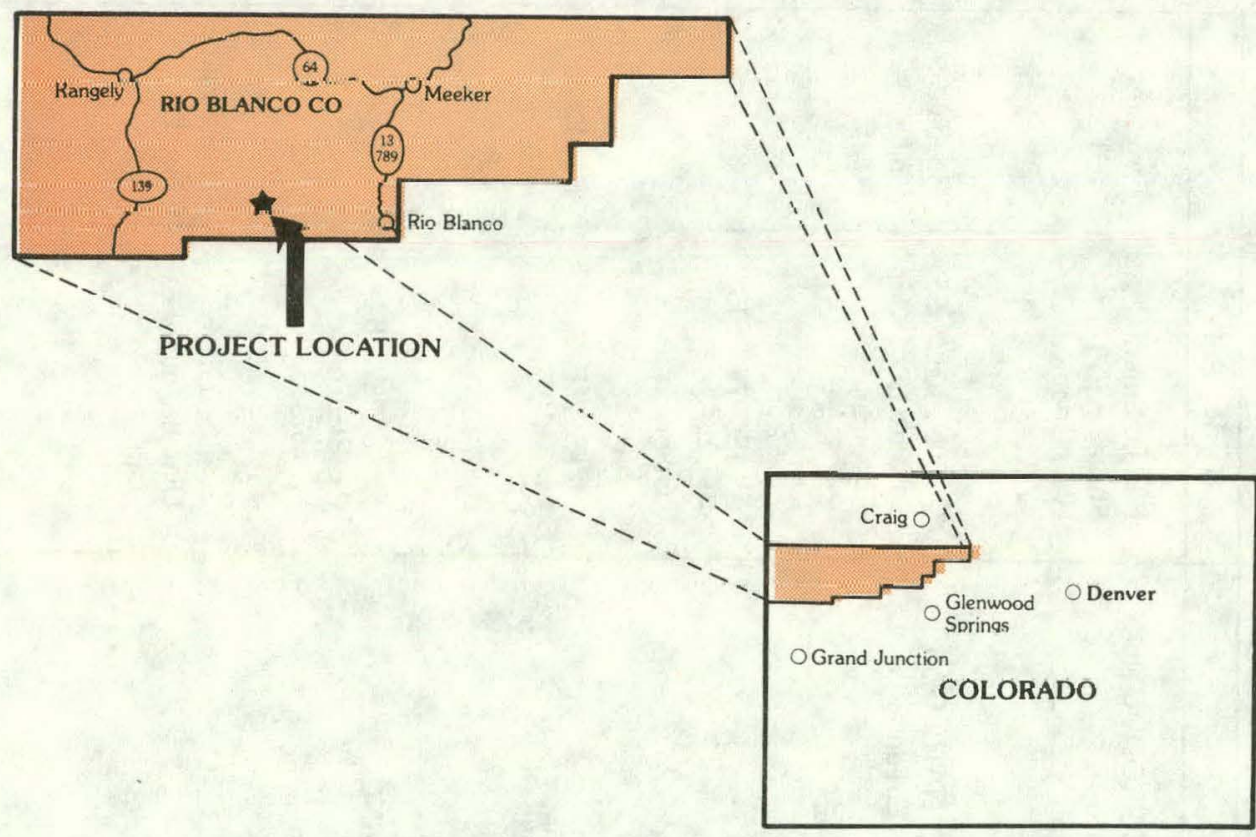




\subsection{CER Corporation}

\subsubsection{Scope of Work}

DOE Contract EY-76-C-08-0623 was signed with CER Corporation in March, 1974. This initiated the fielding of the Rio Blanco Massive Hydraulic Fracturing Project, a joint Industry/Government demonstration to test the relative effectiveness of MHF in gas-bearing formations that were previously stimulated by the Rio Blanco Nuclear Fracturing Experiment, which took place in May, 1973. Both demonstrations are located in the northern part of the Piceance Basin of northwestern Colorado.

\subsubsection{Current Status}

Field activities on the RB-MHF 3 well have been suspended because of lack of funds. Further action is dependent upon the completion of satisfactory contractual arrangements with an outside parly lu cumplete the commingling of the fractured gas zones and to perform additional testing in return for the well and subsequent gas production. 
Colorado Interstate Gas Company Colorado Springs, Colorado
Status: Activity to Commence January 1, 1978

Total Project Cost: (Estimated)

DOE .................... \$75,000

CIG $\ldots \ldots \ldots \ldots \ldots \ldots \ldots \ldots \ldots \ldots, 99,000$

Total ................ $\$ 174,000$

Principal Investigator: Howard Fredrickson

Technical Project Officer for DOE: C. H. Atkinson, Bartlesville Energy

Research Center

\section{OBJECTIVE}

Cyclic injection of dry natural gas is the method to be used to increase produr. tivity of tight gas sands.

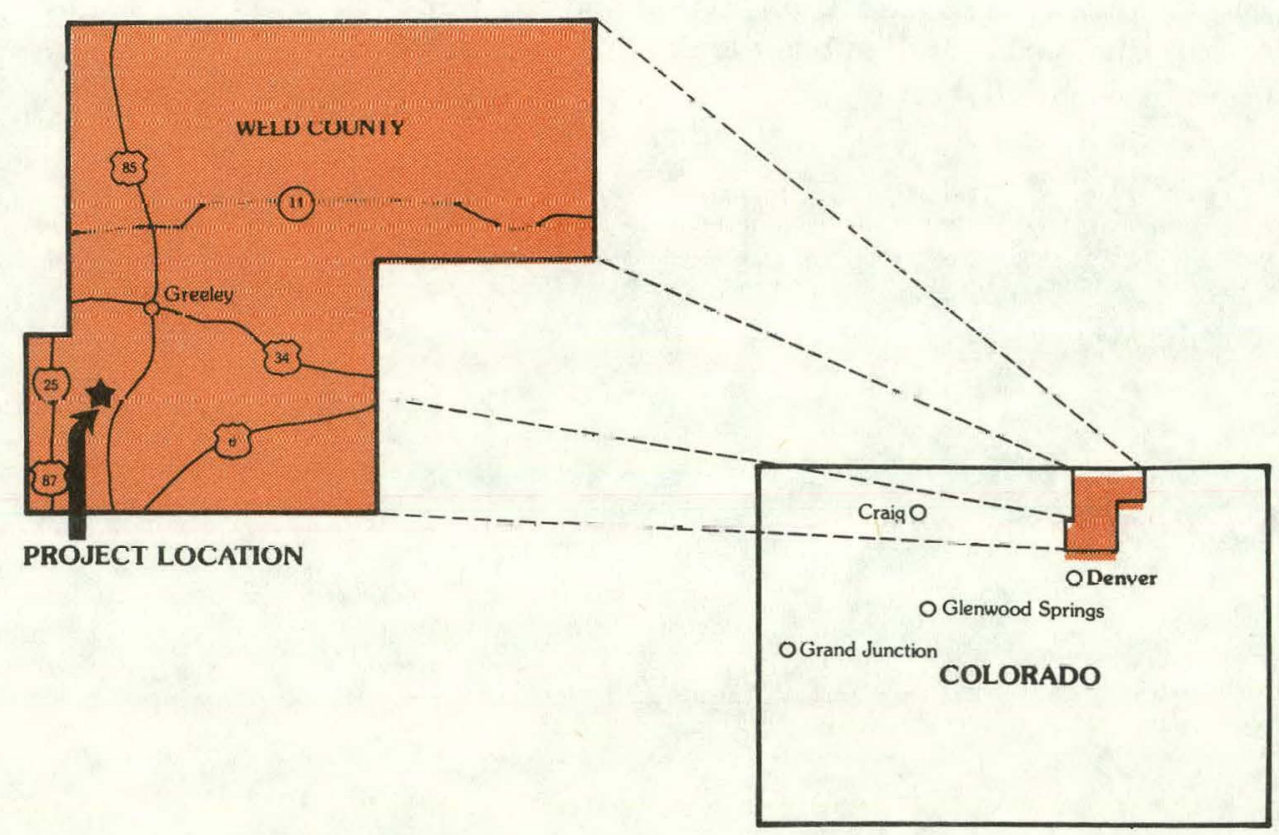




\subsection{Colorado Interstate Gas Company}

\subsubsection{Scope of Work}

On September 1, 1977, Contract No. EY-77-C-08-1514 was entered into between DOE and Colorado Interstate Gas Company (CIG) in the amount of $\$ 75,000$. The contractor will fund the program in the amount of $\$ 99,000$.

The Colorado Interstate Gas Company will attempt to determine if the productivity of wells completed in low permeability natural gas reservoirs can be improved by reducing the interstitial water saturation. The method used to accomplish this reduction of water saturation will be a cyclic injection of dry natural gas. In addition, cyclic injection of dry natural gas may improve the productivity through dehydration of matrix clays and the removal of formation damage adjacent to the surfaces of the induced fracture.

\subsubsection{Current Status}

The survey and drawings of the pipeline route between the two wells have been completed and sent to CIG's Land Department for purchase of the necessary right-of-way and compressor site.

Discussions with compressor vendors on design conditions and specifications are continuing. The Reservoir Engineering Department is reviewing these design conditions and specifications in order to determine if the lower discharge pressure of 1,500 psia will be adequate. 


\section{NATURAL BUTTES UNIT, UINTAH COUNTY, EY-76-C-08-0681 UTAH MASSIVE HYDRAULIC FRACTURING DEMONSTRATION}

Gas Producing Enterprises, Inc.

Status: Active

Subsidiary of Coastal States Gas Co.

Houston, Texas

Contract Date:

Anticipated Completion:

Total Project Cost: (Estimated)

Princiud Irivestiuatur:

Technical Project Officer:
July 1, 1976

Sept. 30, 1978

DUE .................... $\$ 2,827,000$

Industry (prior costs) $\ldots \ldots \ldots \ldots \ldots, 1,881,000$

Industry (new costs) $\ldots \ldots \ldots \ldots \ldots, 3,051,000$

Total ................\$7,759,000

W. E. Spencer

C. H. Atkinson, Bartlesville Energy

Research Center

\section{OBJECTIVE}

To evaluate the effectiveness of massive hydraulic fracturing for stimulating natural gas production from thick, deep sandstone reservoirs having low permeability.

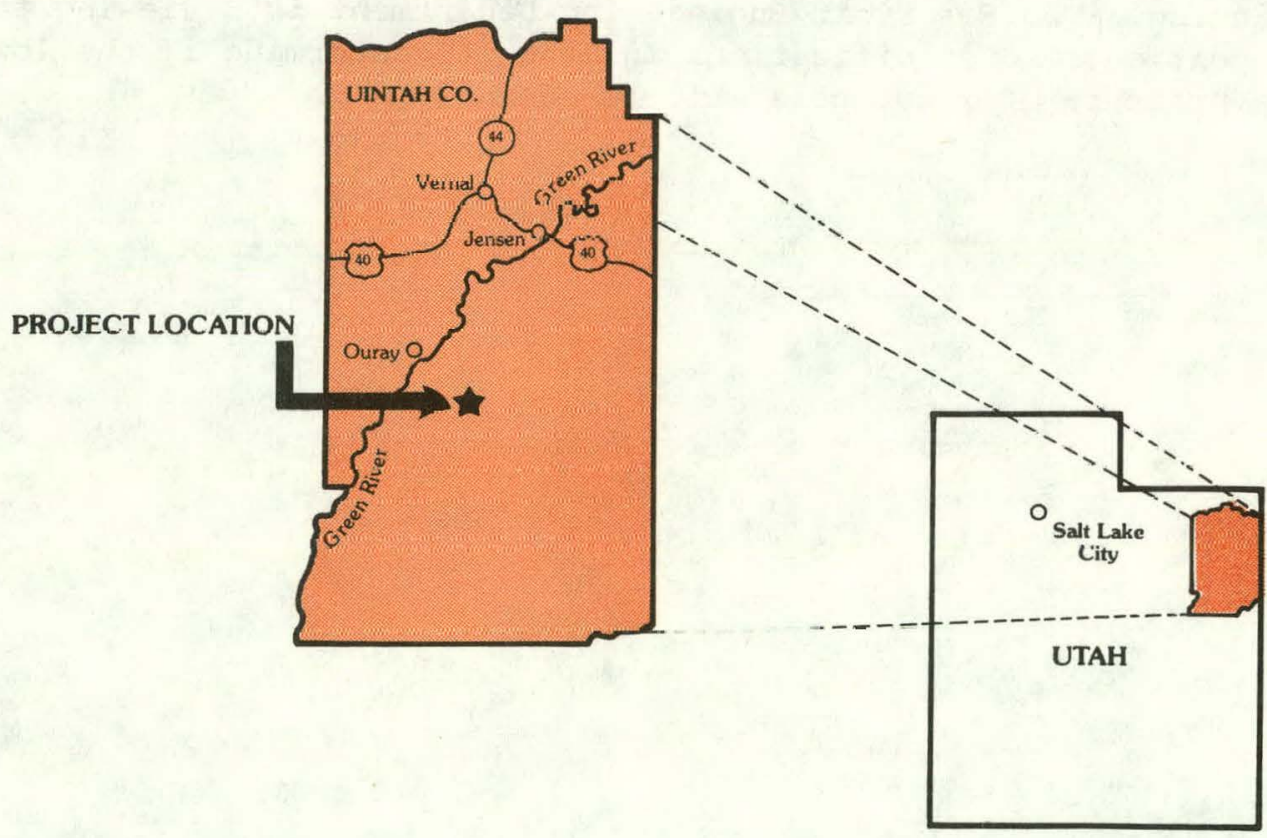




\subsection{Gas Producing Enterprises Inc.}

\subsubsection{Scope of Work}

On July 1, 1976, a Contract, EY-76-C-08-0681, was entered into between DOE and Gas Producing Enterprises Inc. concerning the conduct of a MHF experimental program. The GPE program was greater in scope compared to the other MHF contracting companies. Orginally, two old wells; Natural Buttes 18 and 14, and four new wells; 19, 20, 21 and 22 were to be fractured. Variations between wells were to consist of amounts of frac fluid, sand size, porosity of zone tested and fluid design. Contract Modification No. 1 added Natural Buttes No. 9, an old well, to the fracturing program. Another contract modification for Phase $V$ of the MHF Demonstration Contract provides for an add-on to the Natural Buttes 21 (tentative new designation is CIGE No. 21) for coring, running of extra logs, and to run production and buildup tests on individual sand members within two sections of the Mesaverde. The core data, including special interpretation, and production test data will be correlated. In addition, there will be an attempt to obtain post MHF performance of these individual sand members for better prediction of potential productivity of a sand member by electric log interpretation alone.

\subsubsection{Current Status}

Natural Buttes Unit Wells No. 14, 18 and 19 were flowing to sales during February. Well No. 20 was furnishing fuel gas for drilling operations and had restricted gas flow. Specific production data for these four wells appears in Figures 5-1, 5-3, 5-5, and 5-7.

Natural Buttes Unit Well No. 22 is flowing to the pit to unload frac fluids. Well No. 21 and 23 are shut in waiting on completion. 


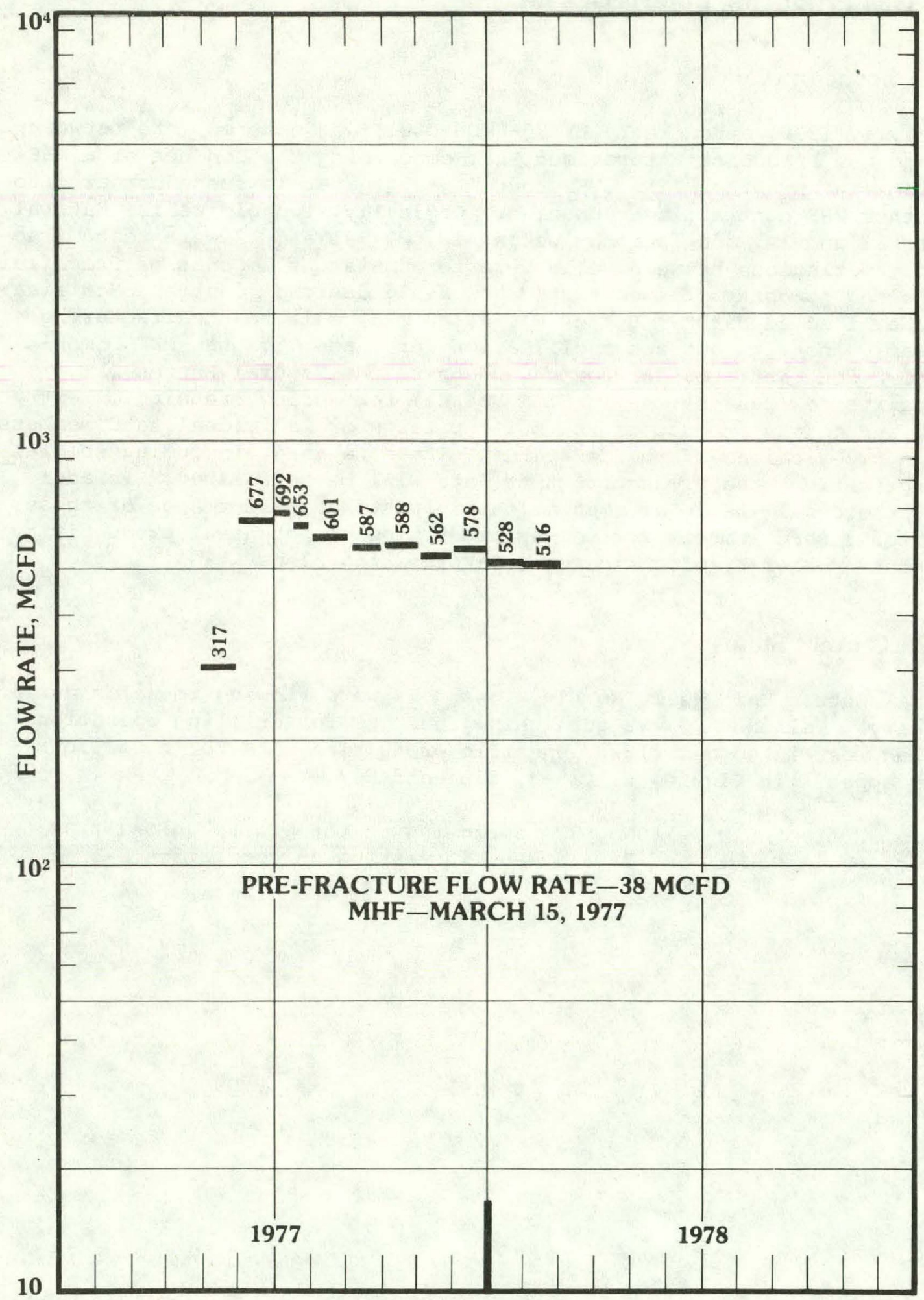

FIGURE 5-1 FLOW RATE PERFORMANCE OF NATURAL BUTTES NO. 14 WELL 


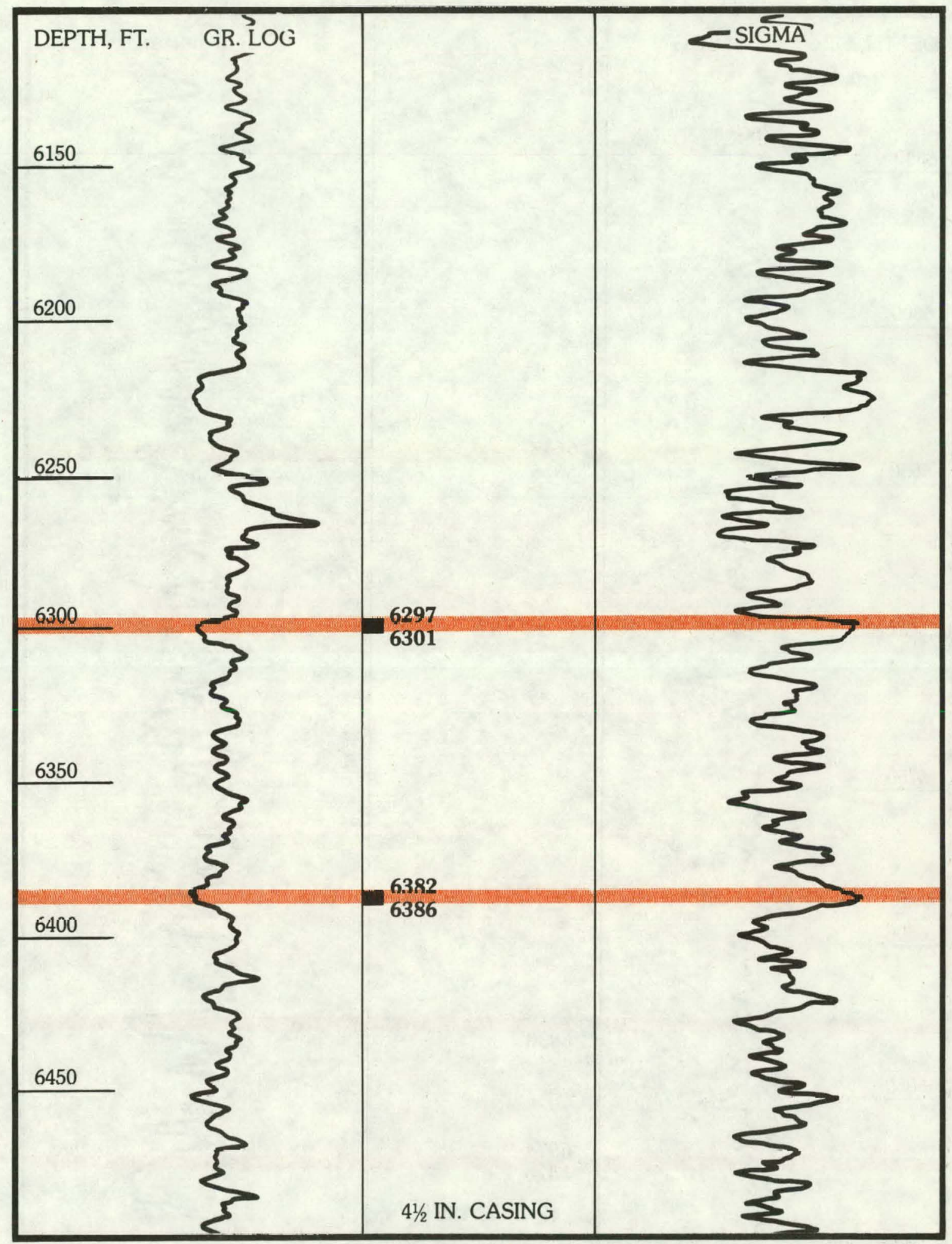

FIGURE 5-2 NATURAL BUTTES NO. 14 WELL SHOWING SANDS FRACTURED 


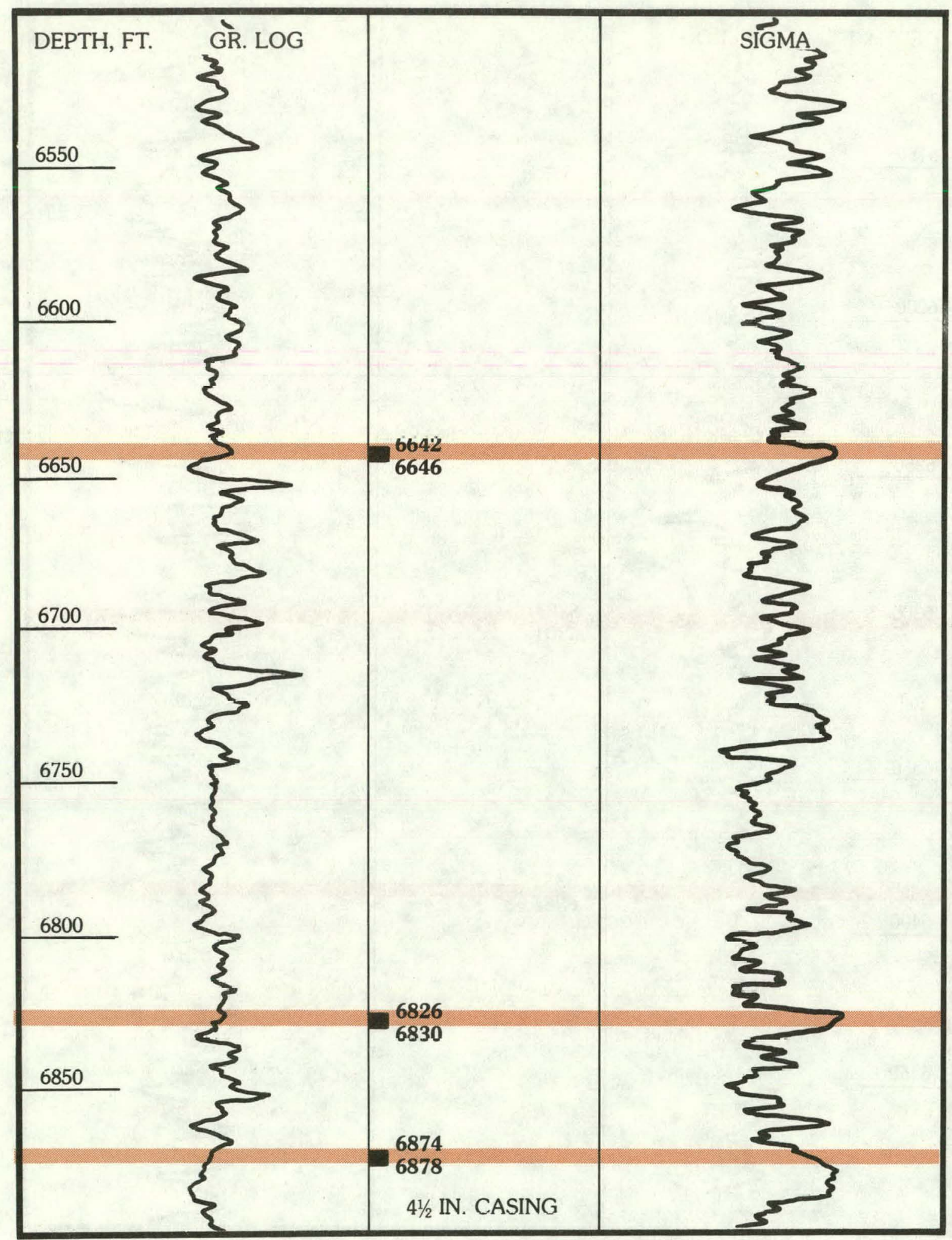

FIGURE 5-2 CONTINUED 


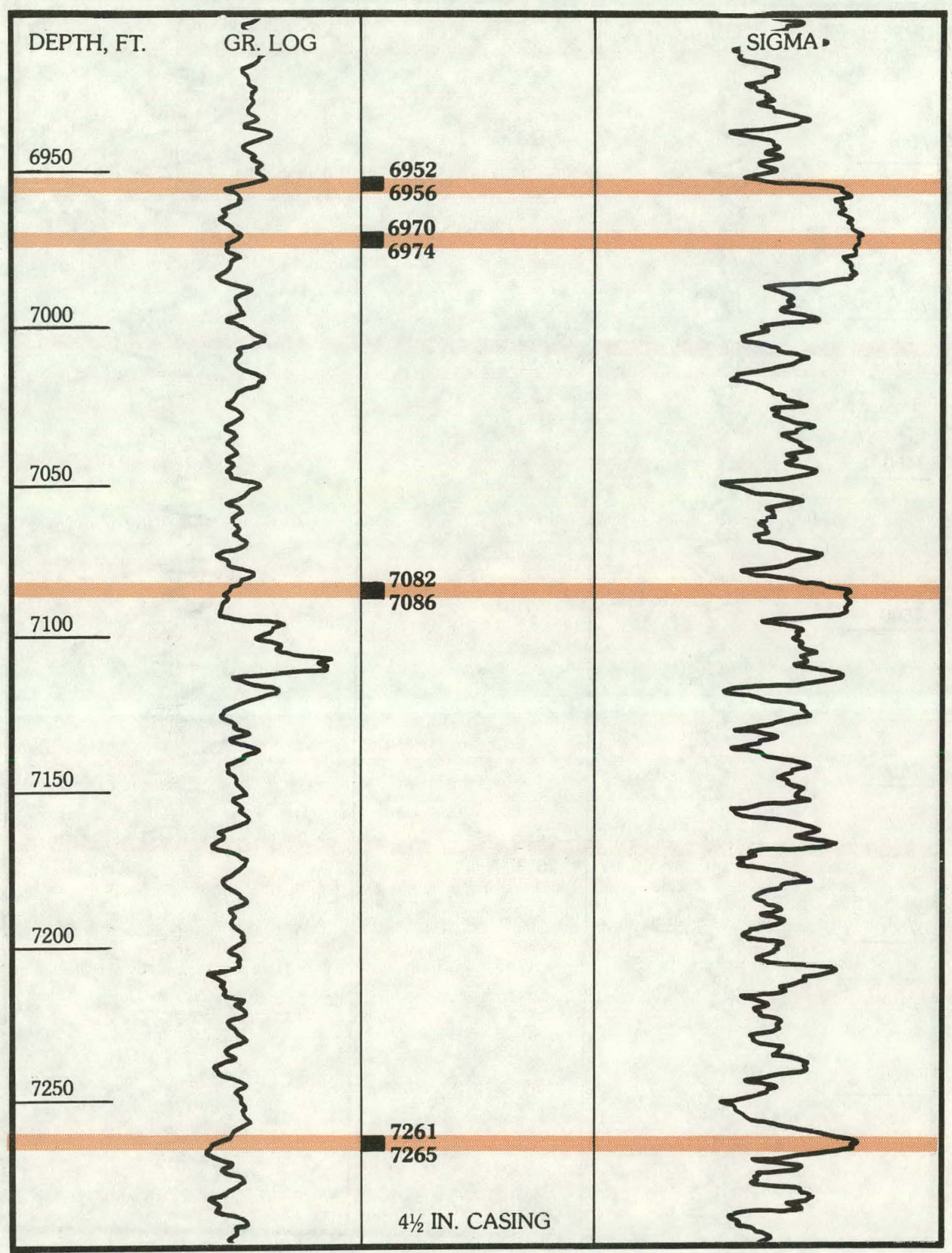

FIGURE 5-2 CONTINUED 


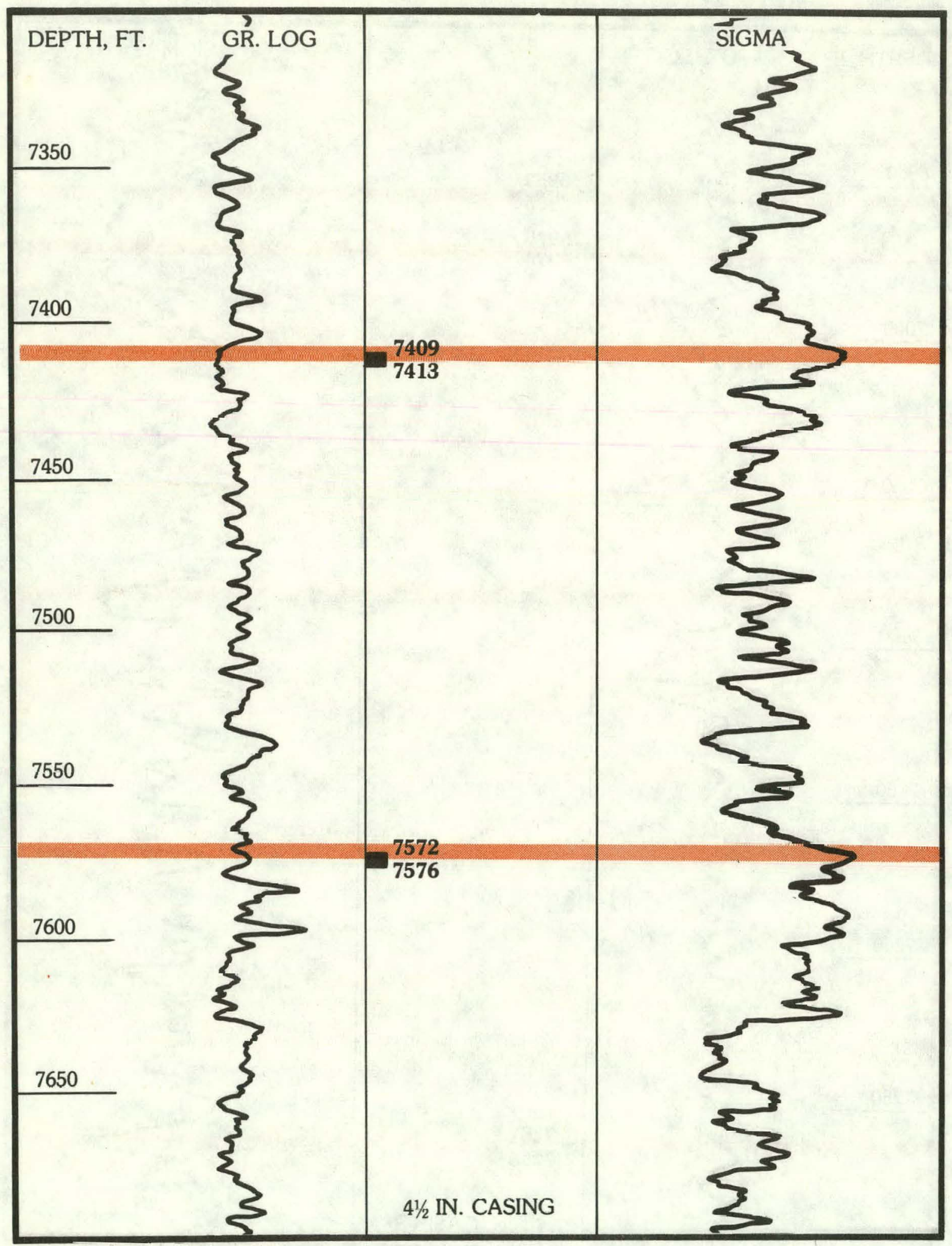

FIGURE 5-2 CONTINUED 


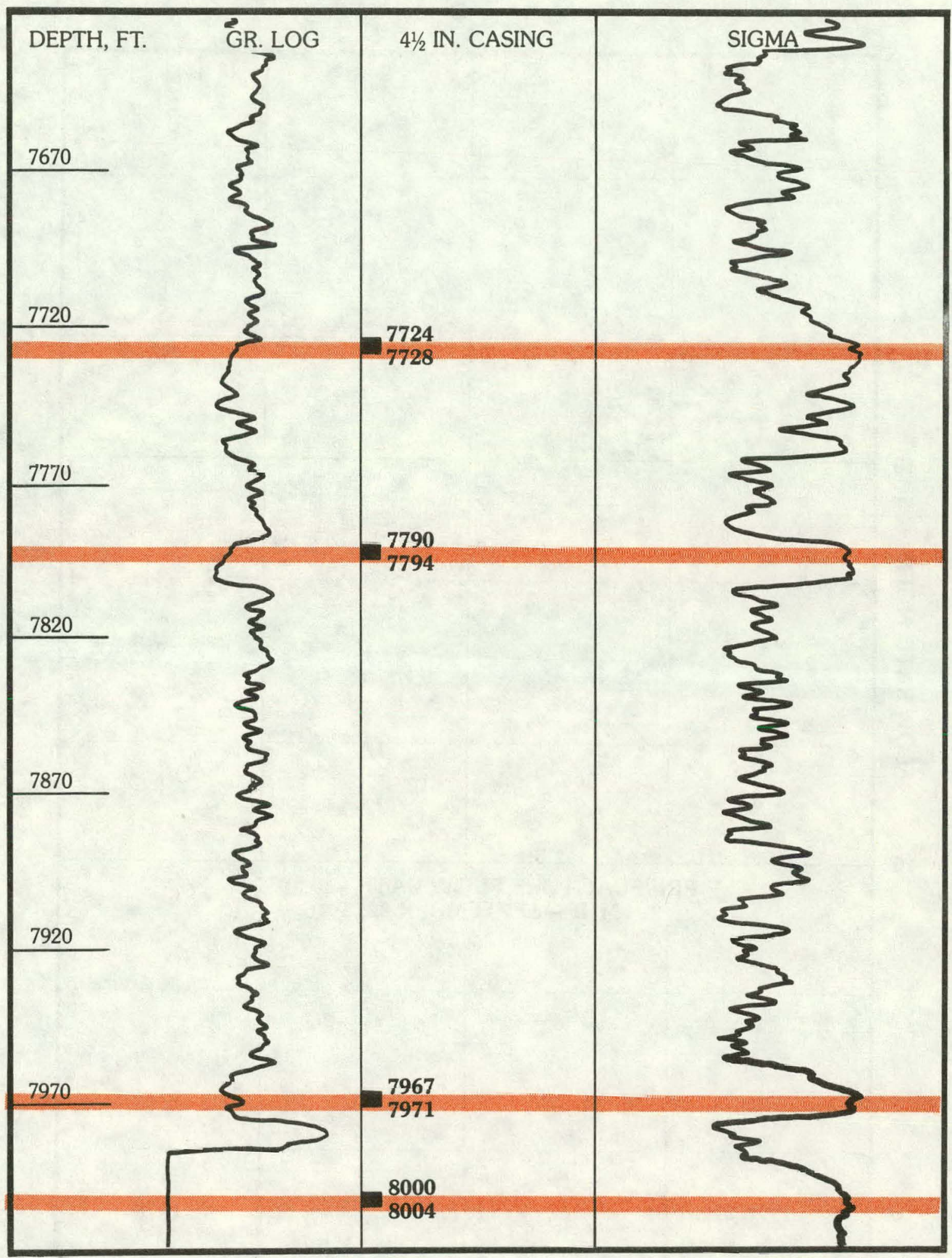

FIGURE 5-2 CONTINUED 


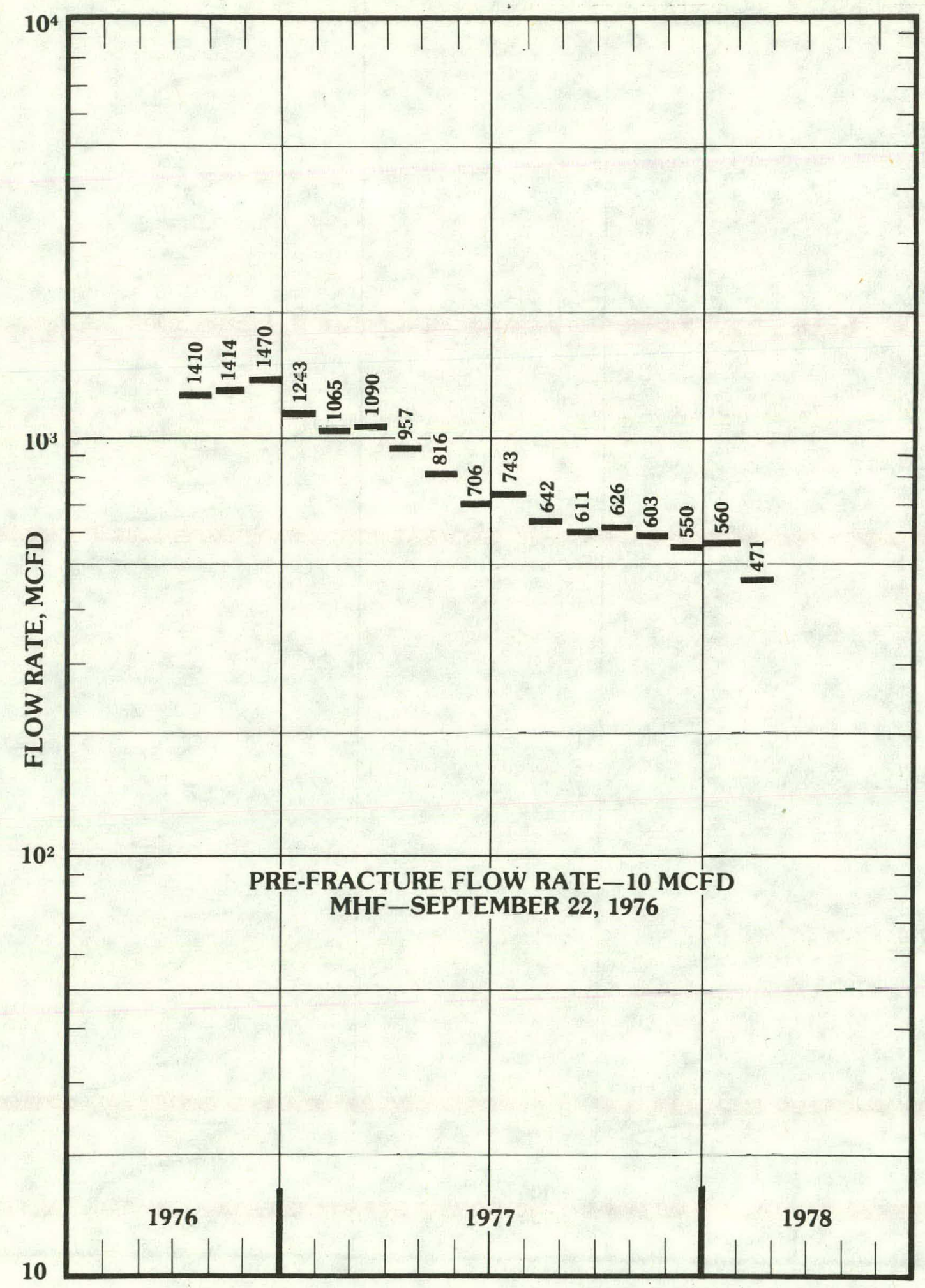

FIGURE 5-3 FLOW RATE PERFORMANCE OF NATURAL BUTTES NO. 18 WELL 


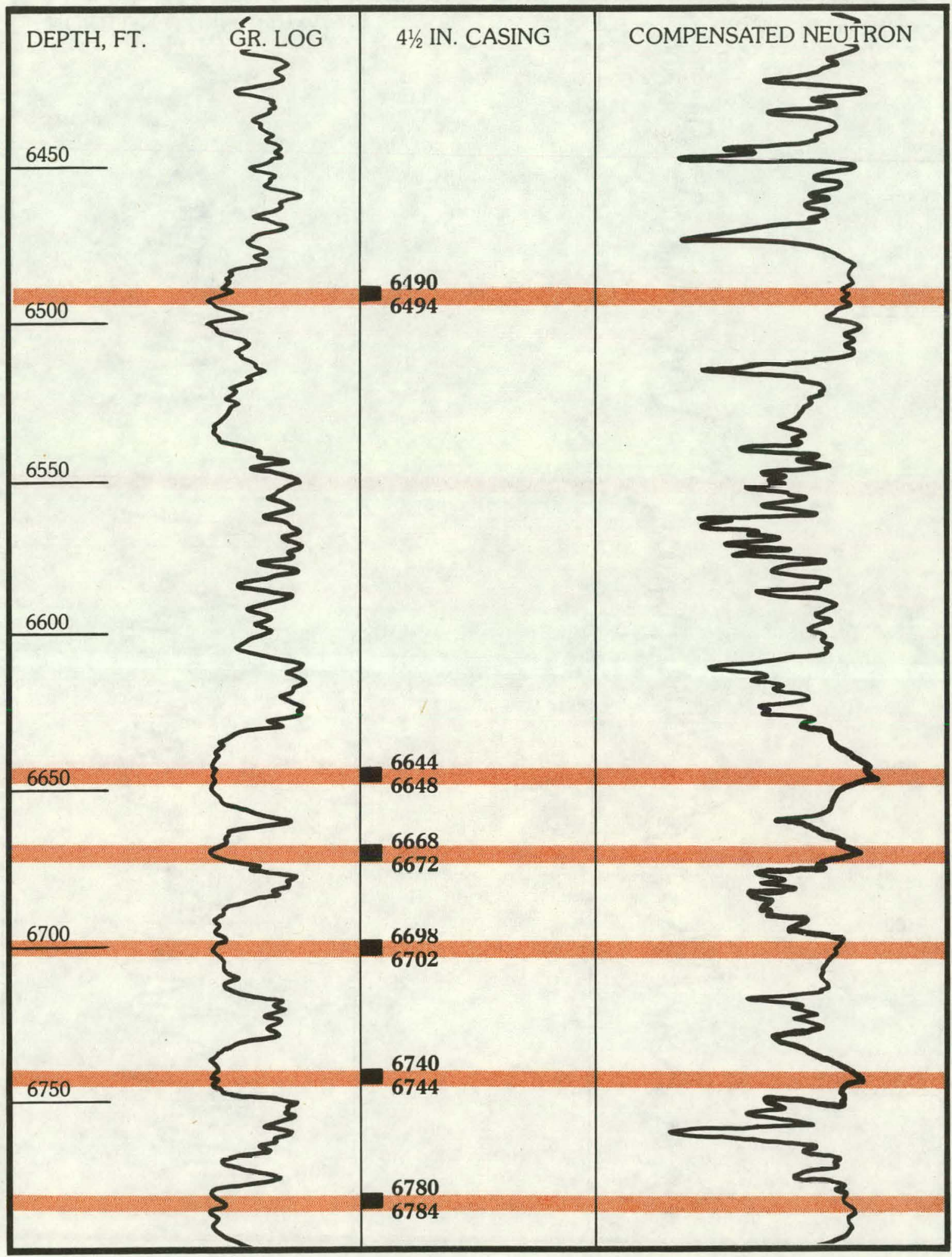

FIGURE 5-4 NATURAL BUTTES NO. 18 WELL SHOWING SANDS FRACTURED 


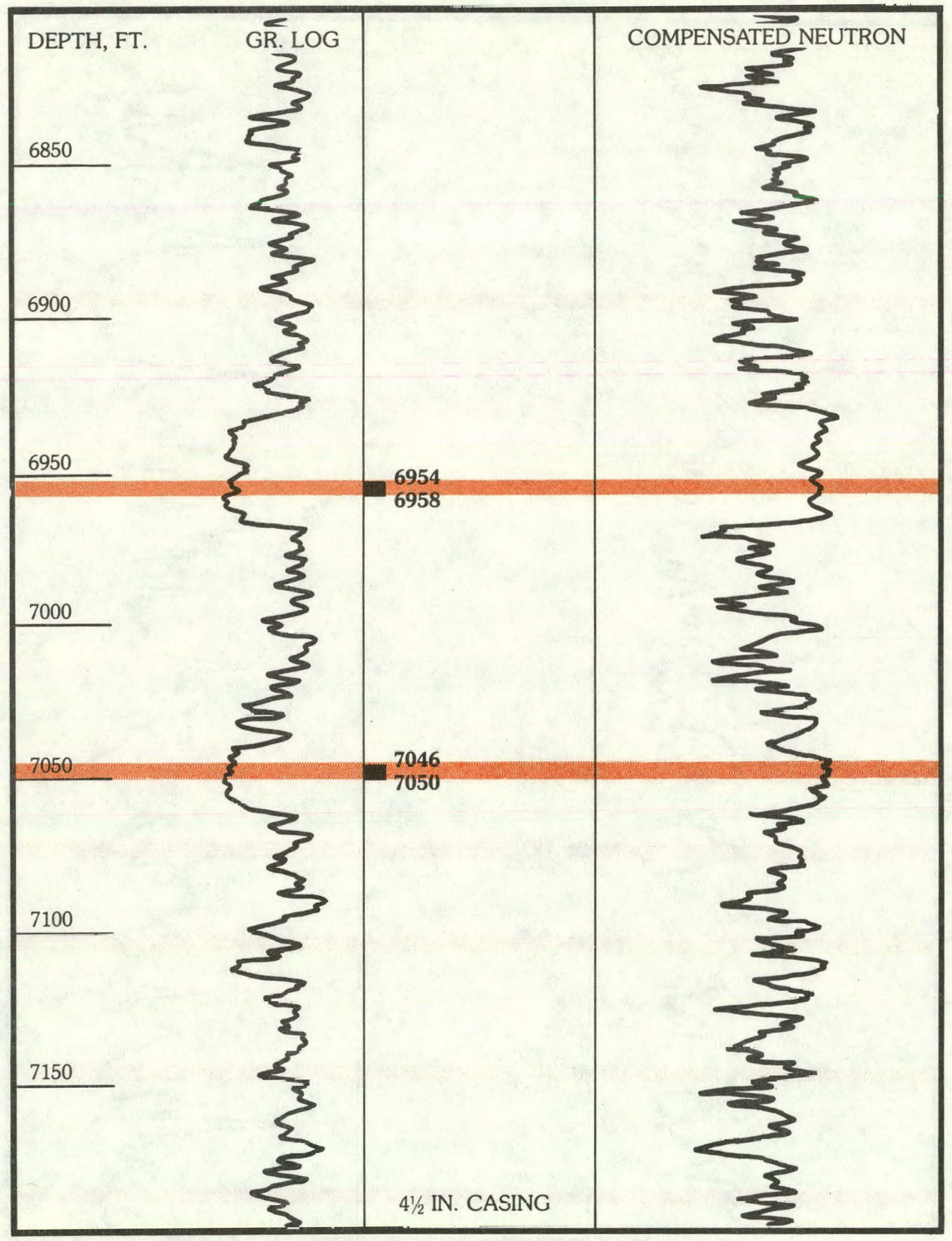

FIGURE 5-4 CONTINUED 


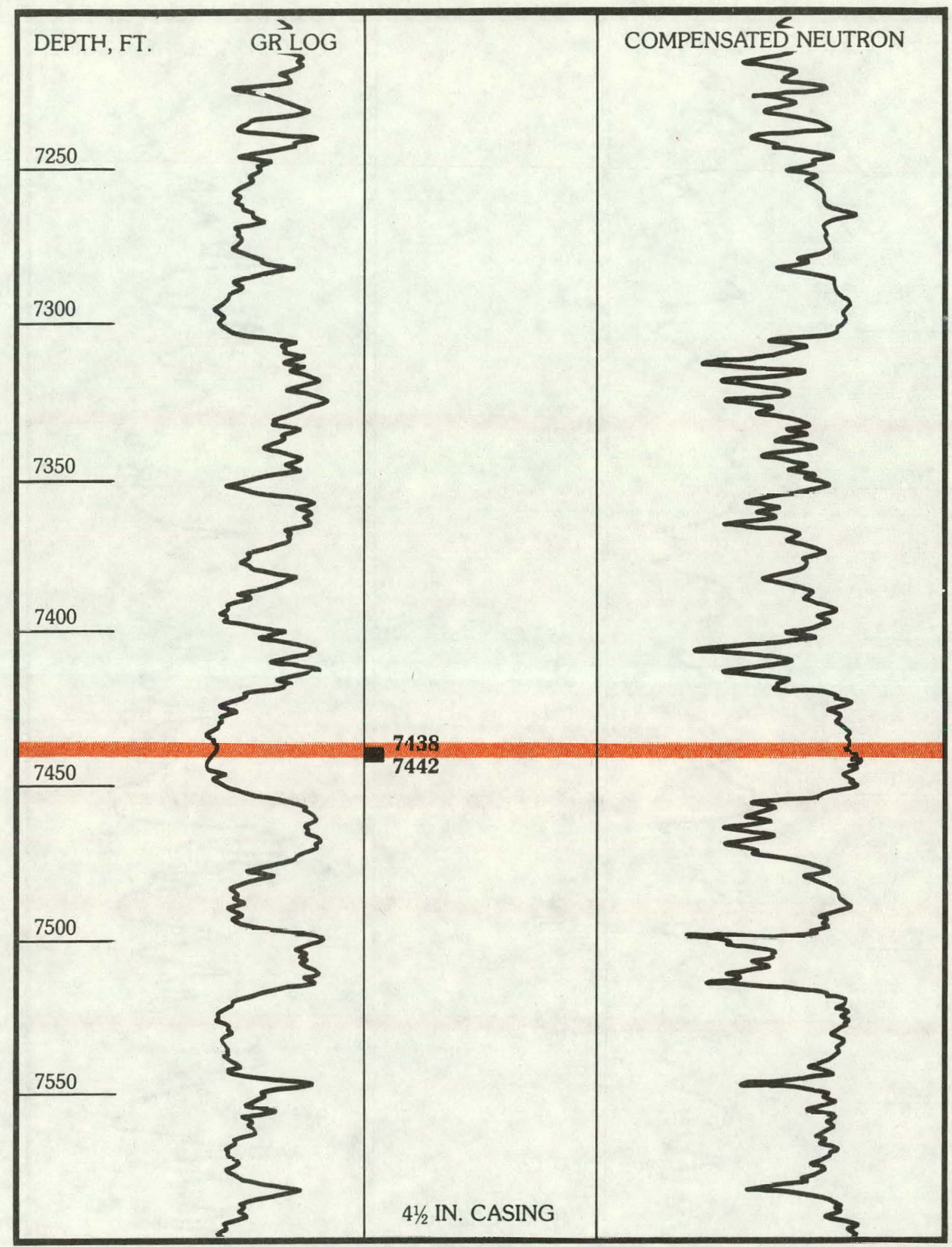

FIGURE 5-4 CONTINUED 


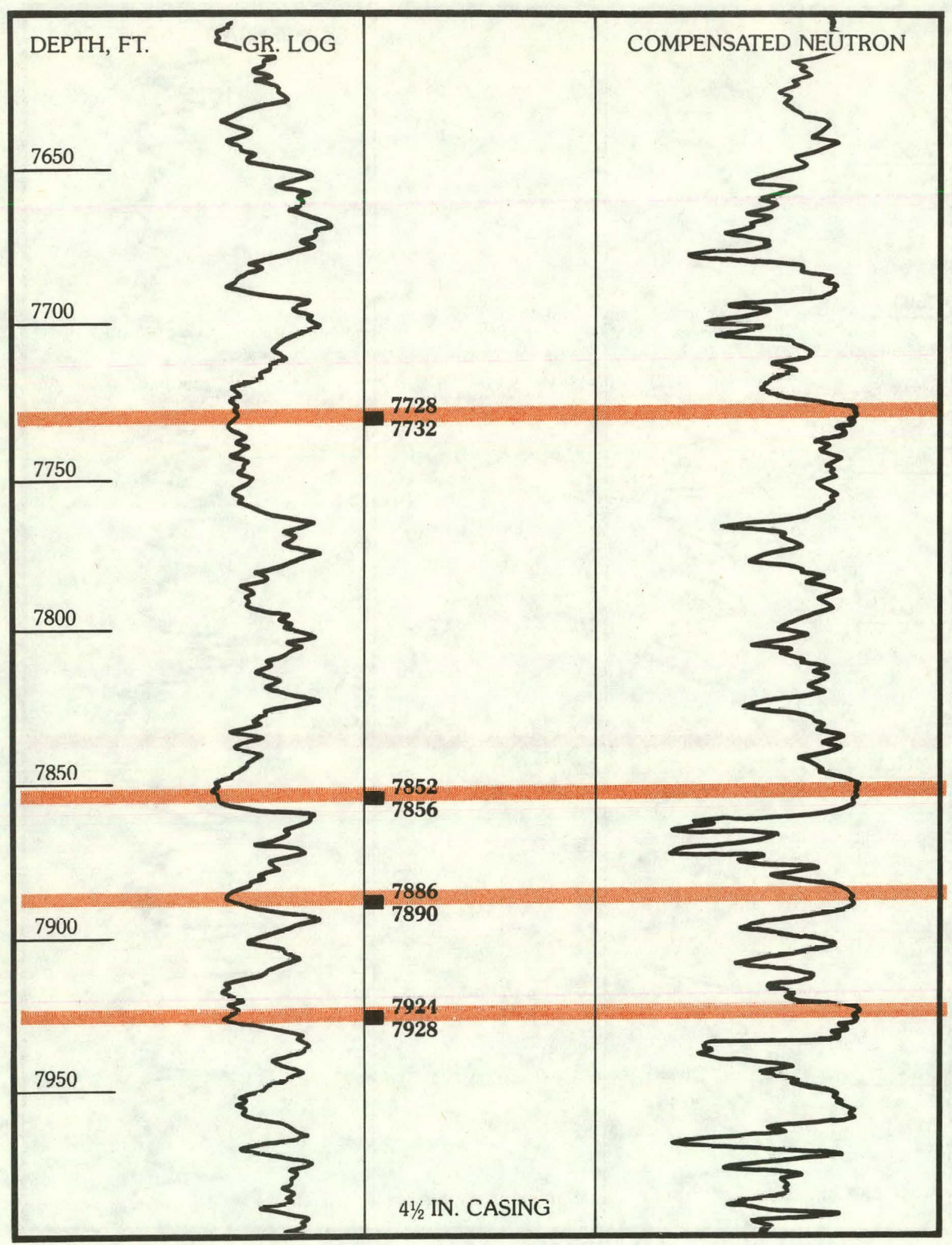

FIGURE 5-4 CONTINUED 


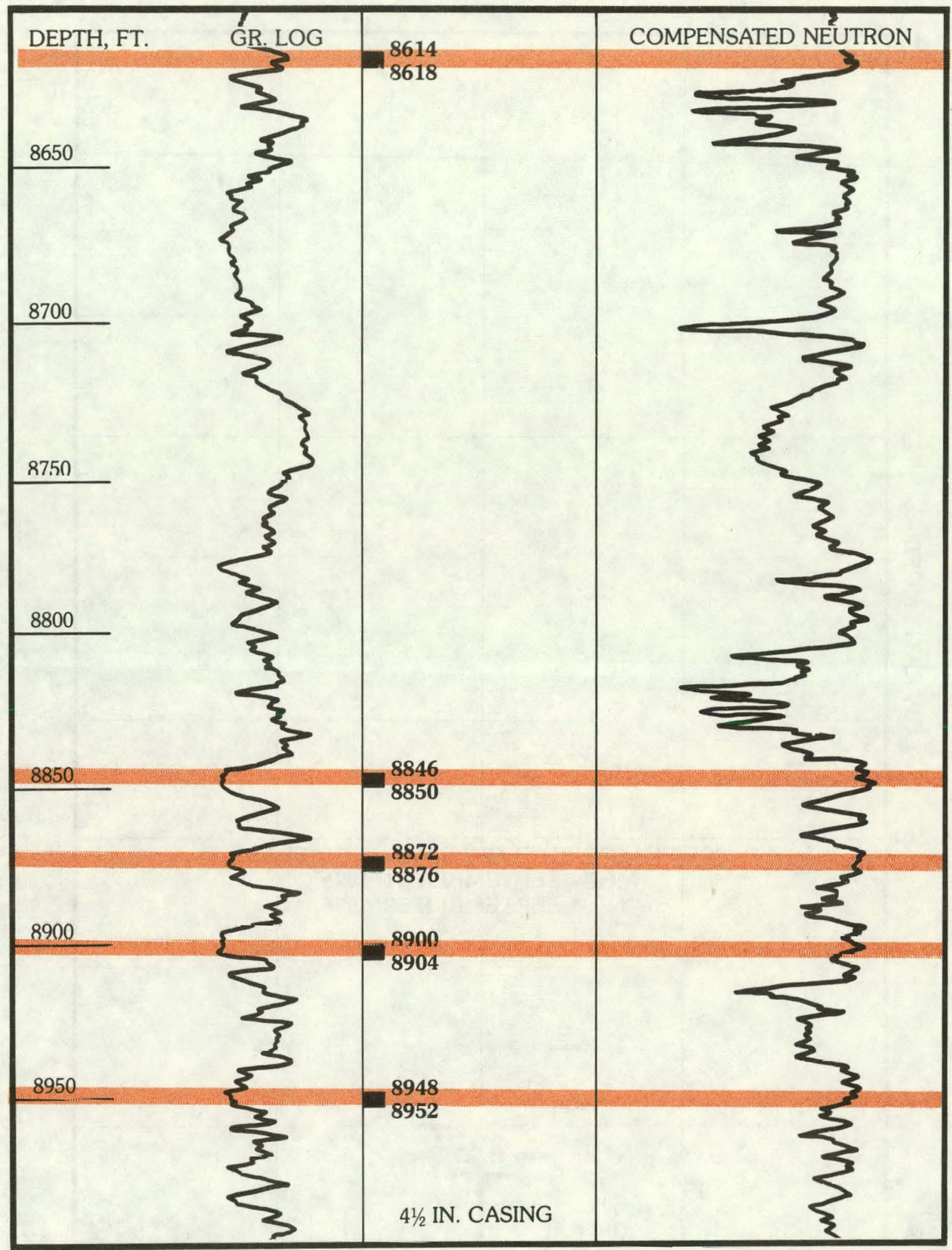

FIGURE 5-4 CONTINUED 


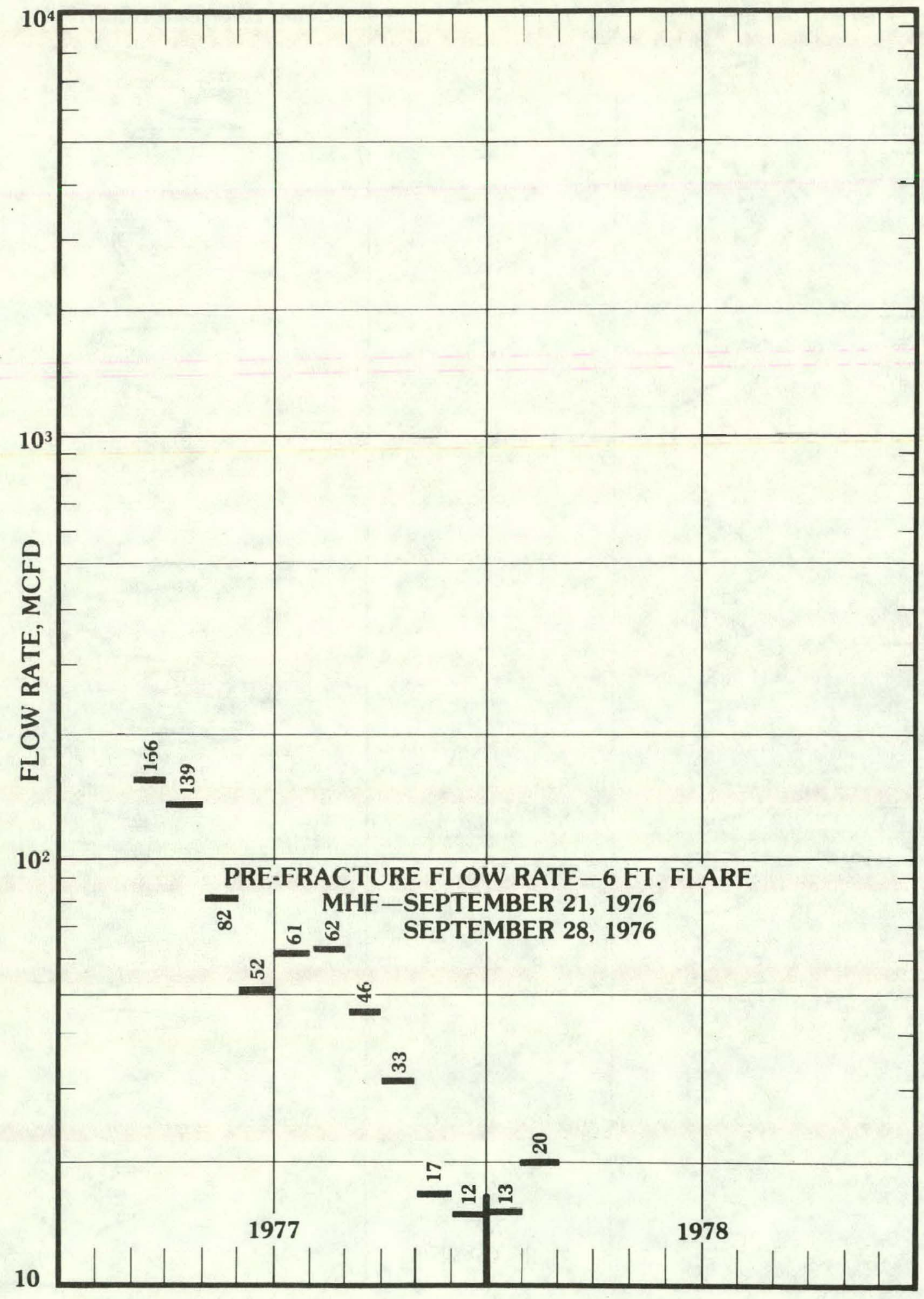

FIGURE 5-5 FLOW RATE PERFORMANCE OF NATURAL BUTTES NO. 19 WELL 


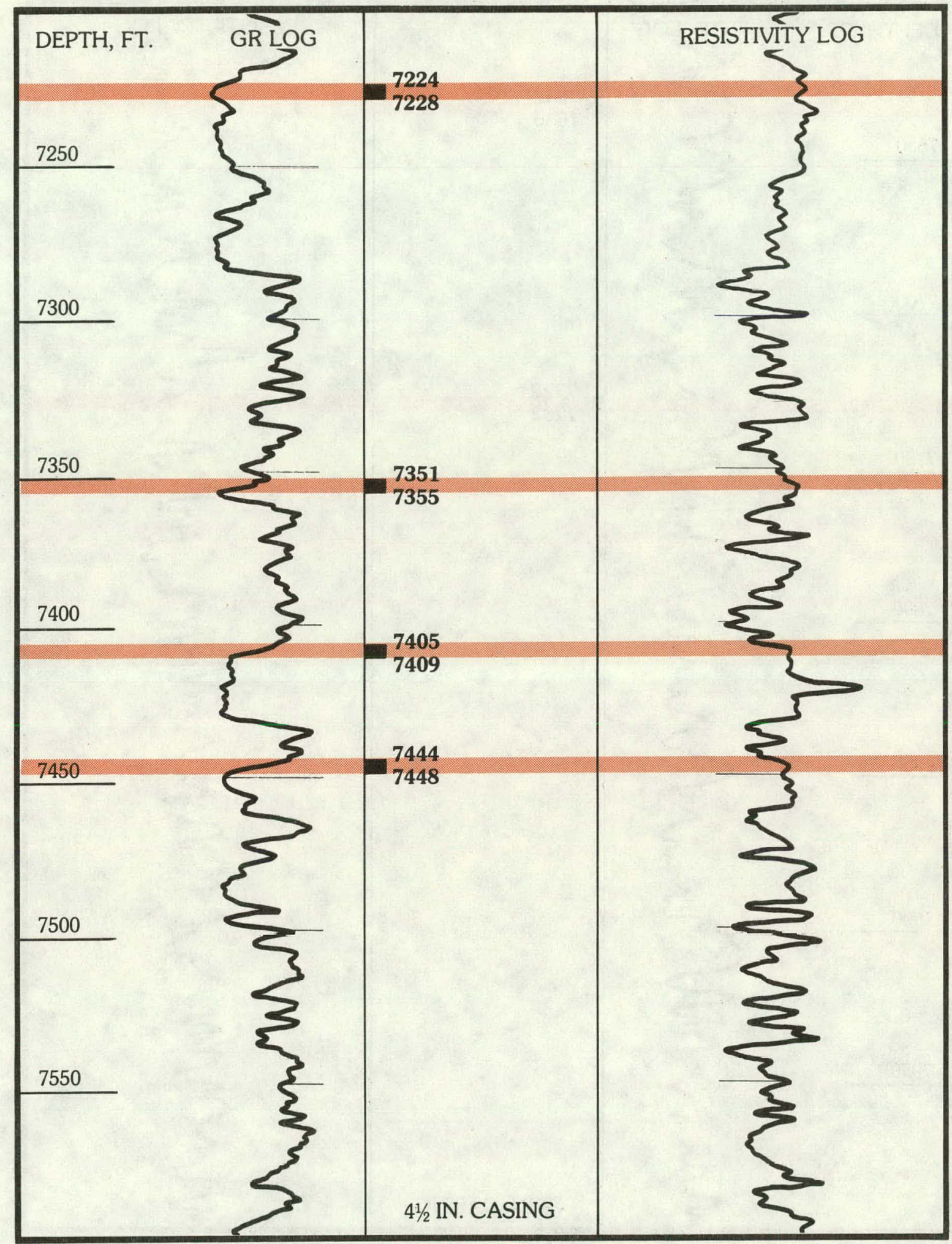

FIGURE 5-6 NATURAL BUTTES NO. 19 WELL SHOWING SANDS FRACTURED 


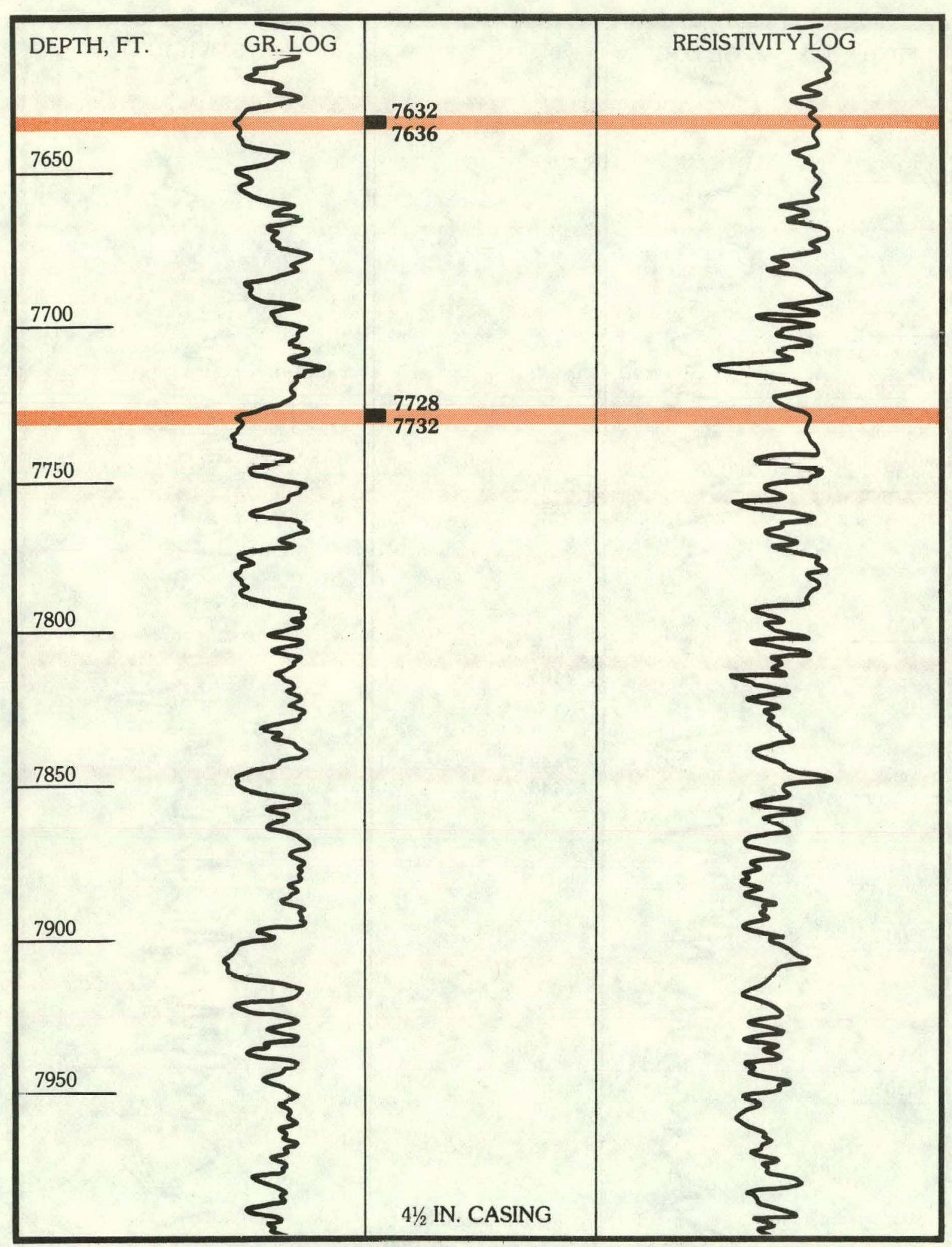

FIGURE 5-6 CONTINUED 


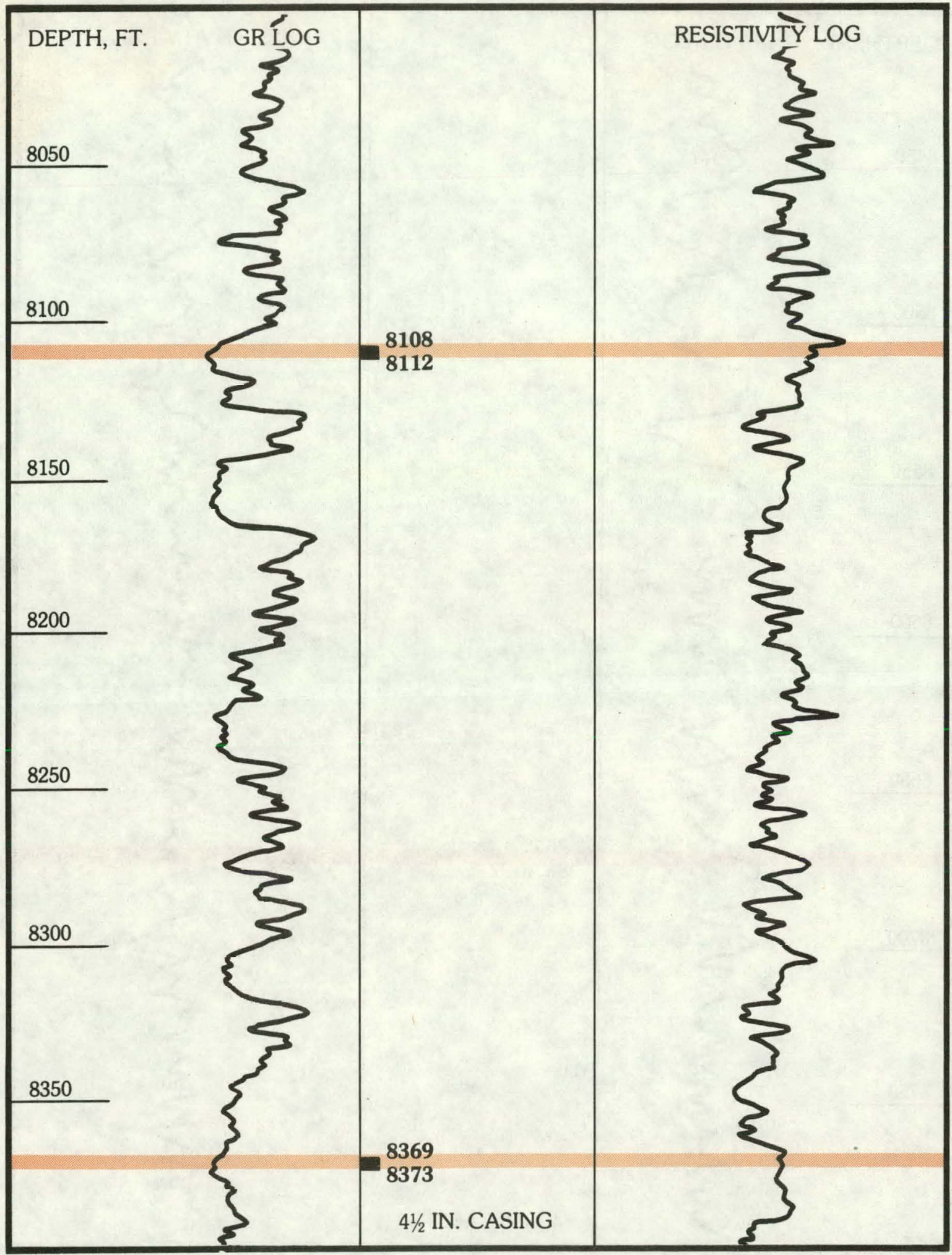

FIGURE 5-6 CONTINUED 


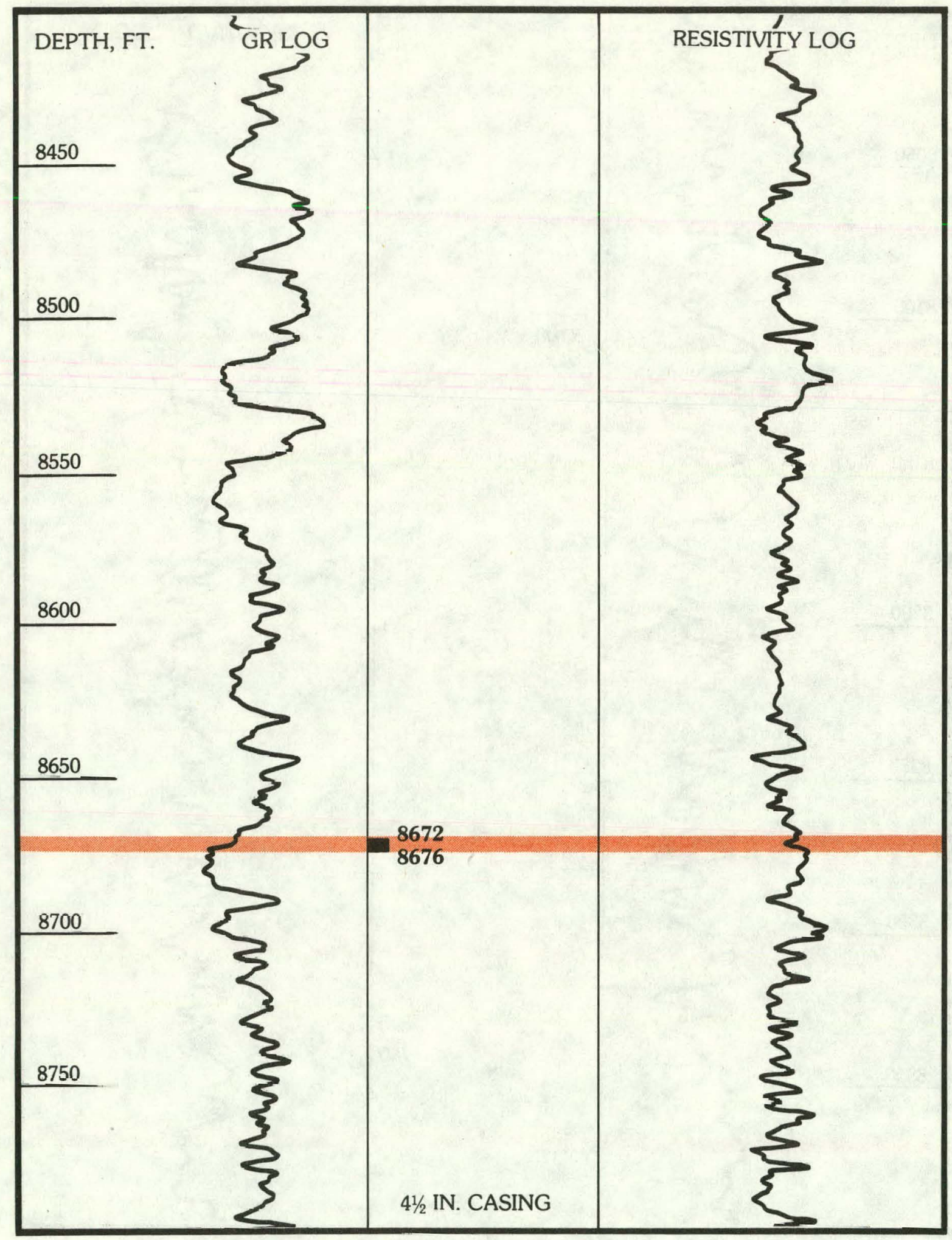

FIGURE 5-6 CONTINUED 


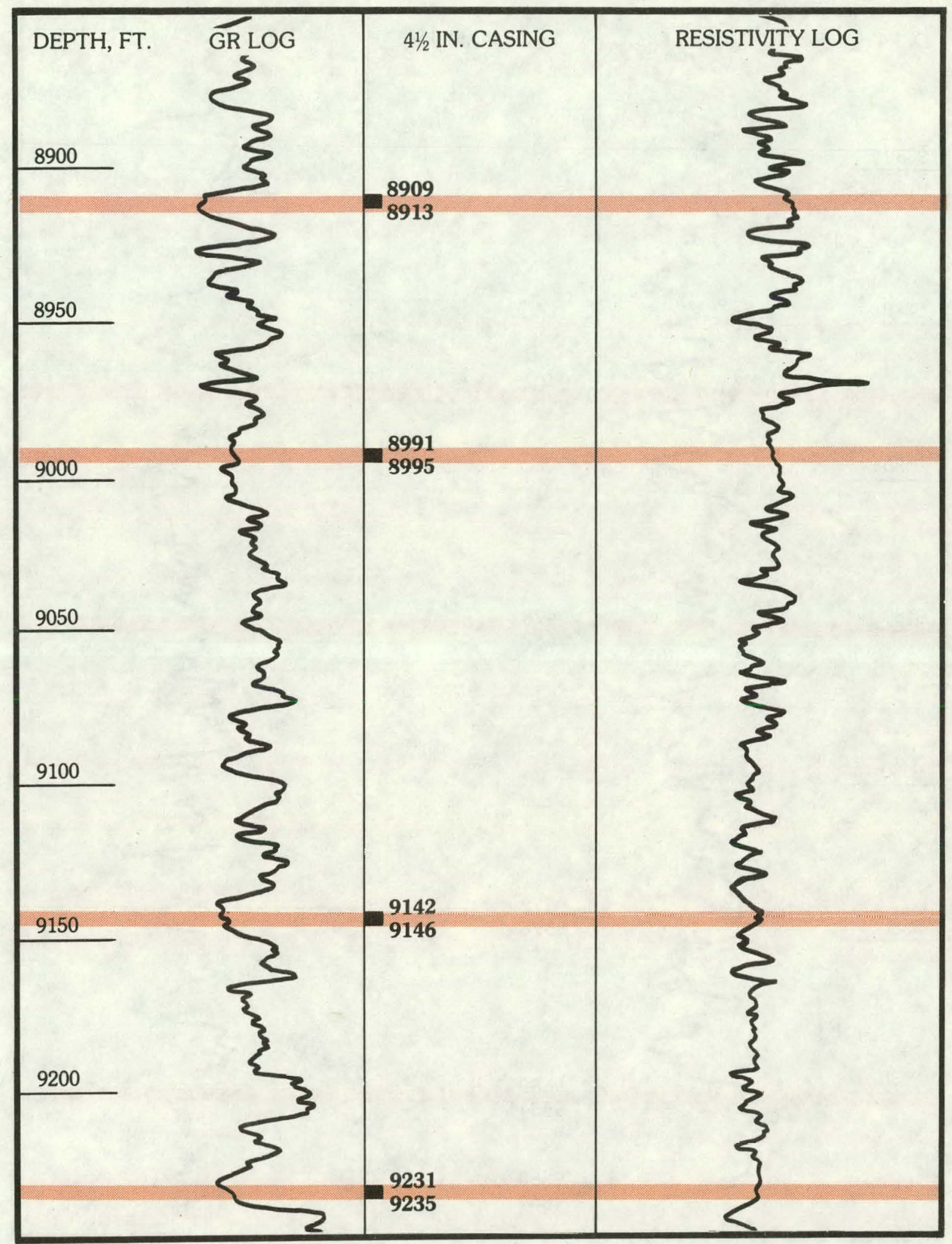

FIGURE 5-6 CONTINUED 


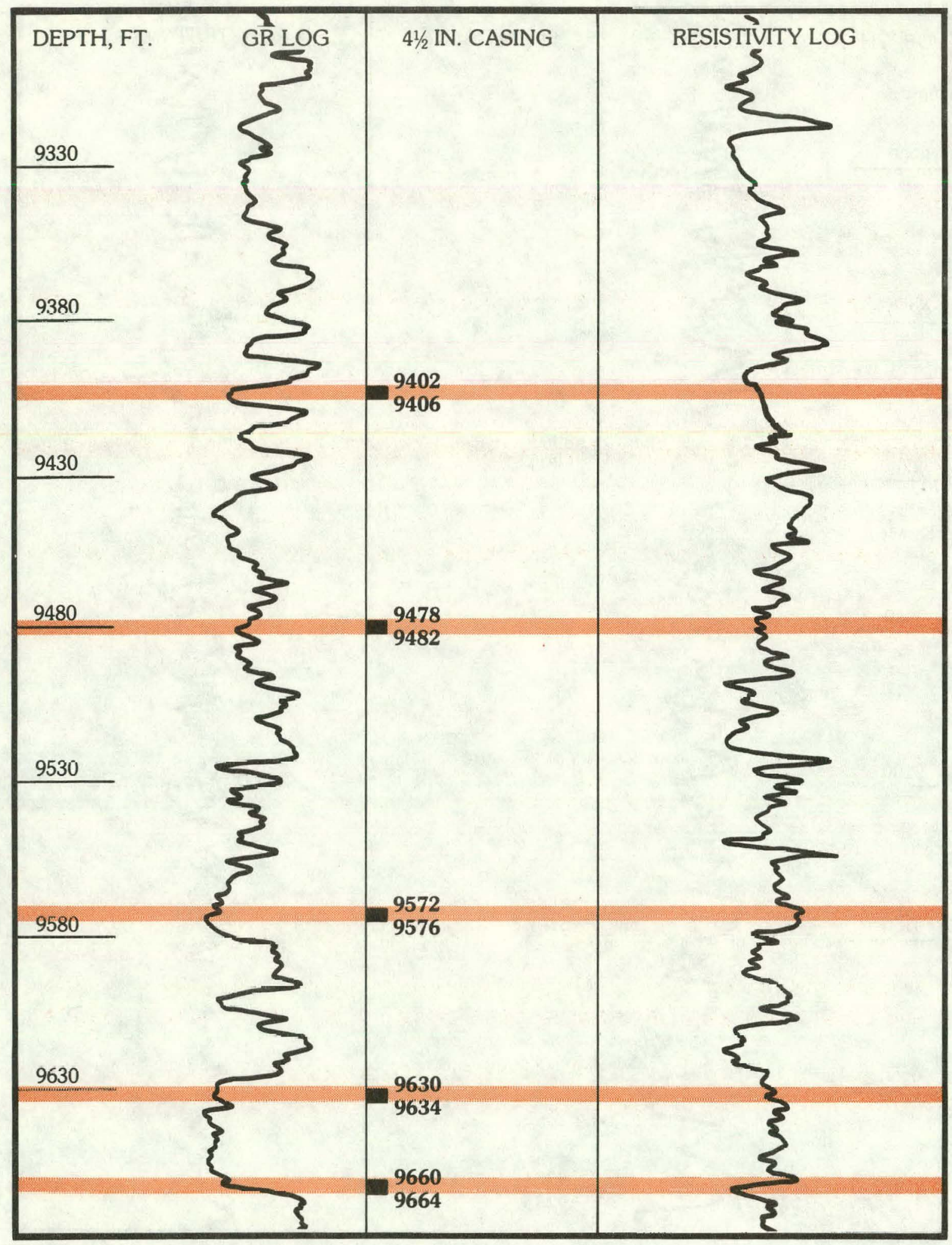

FIGURE 5-6 CONTINUED 


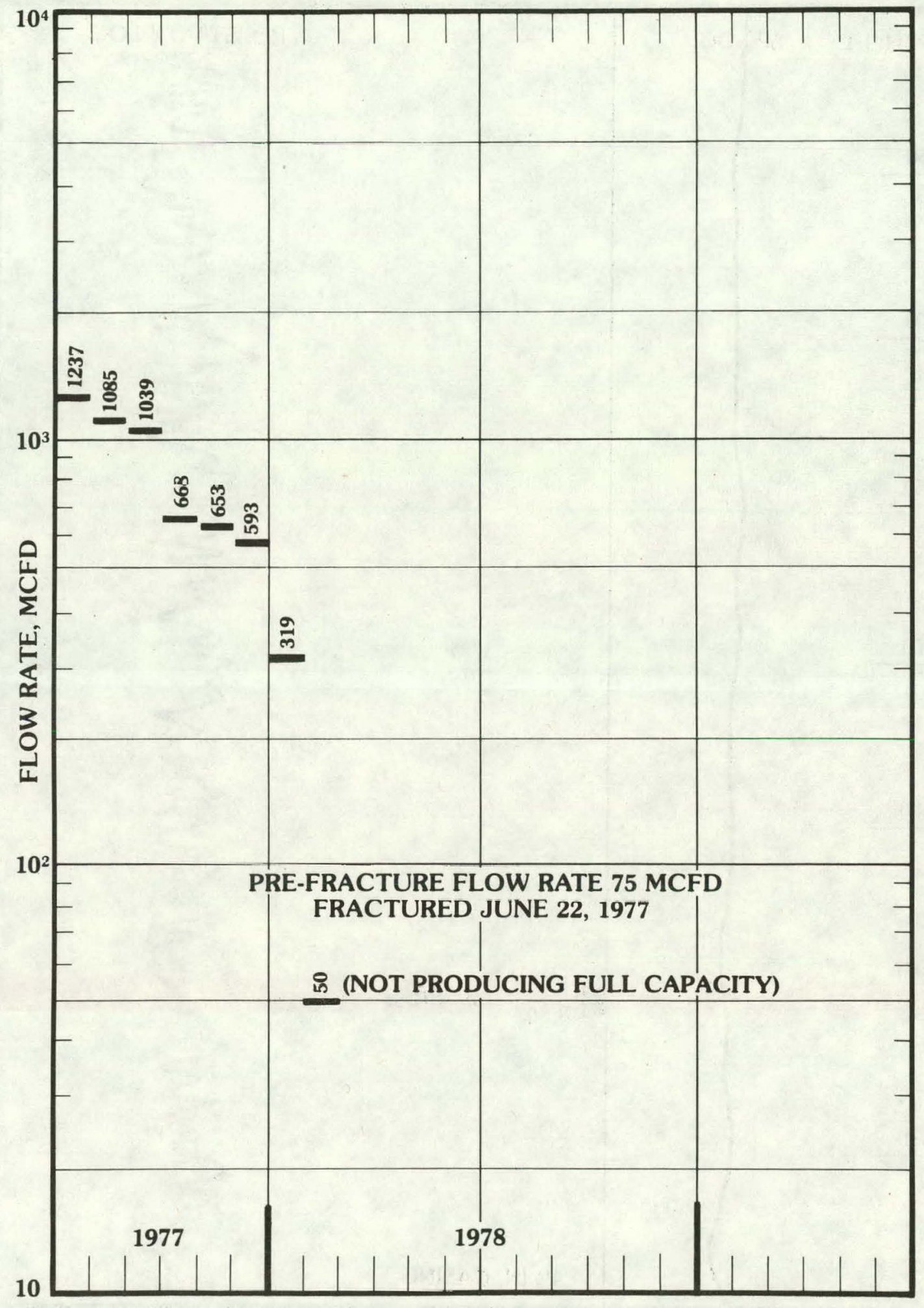

FIGURE 5-7 FLOW RATE PERFORMANCE OF NATURAL BUTTES NO. 20 WELL 


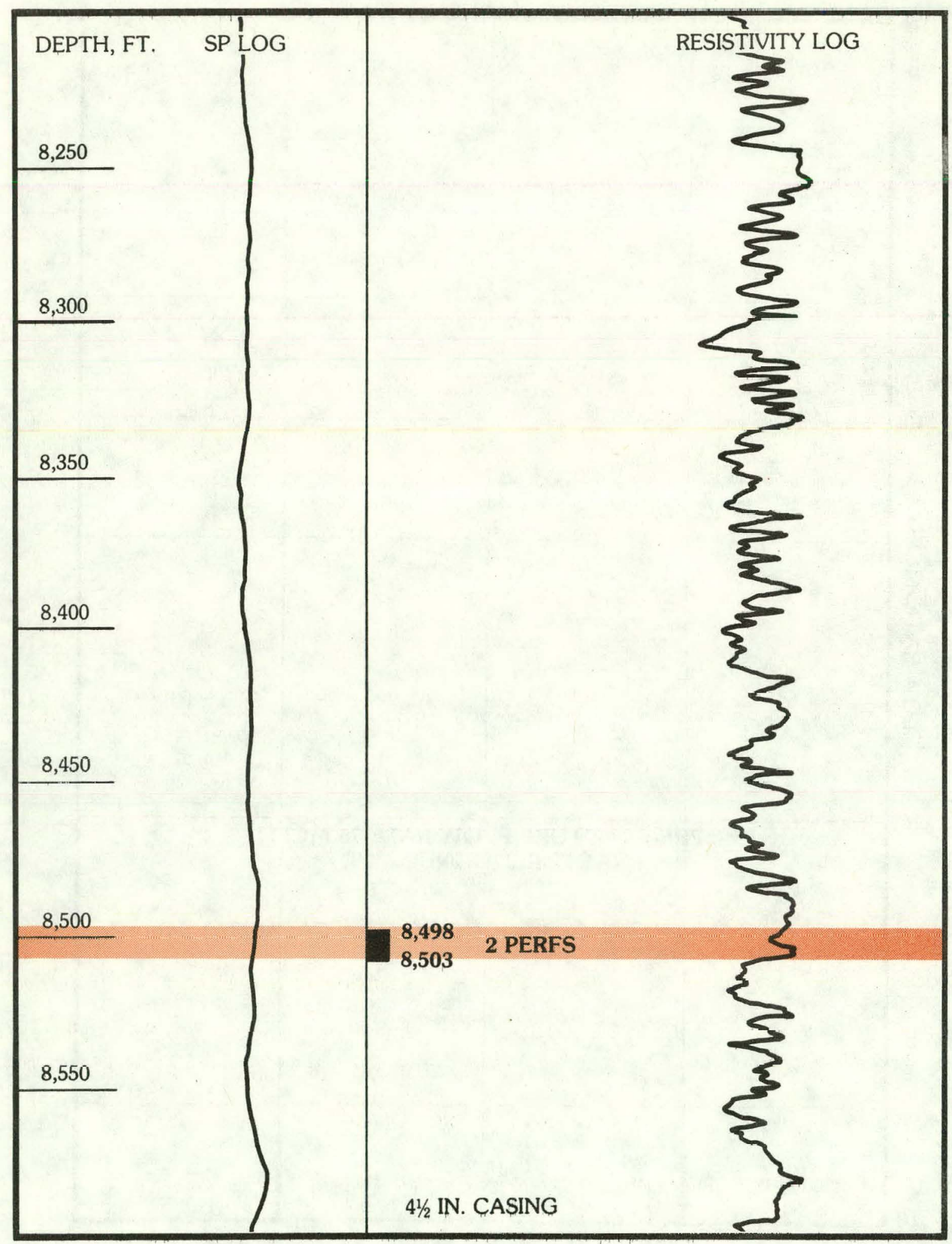

FIGURE 5-8 NATURAL BUTTES NO. 20 WELL SHOWING SANDS FRACTURED 


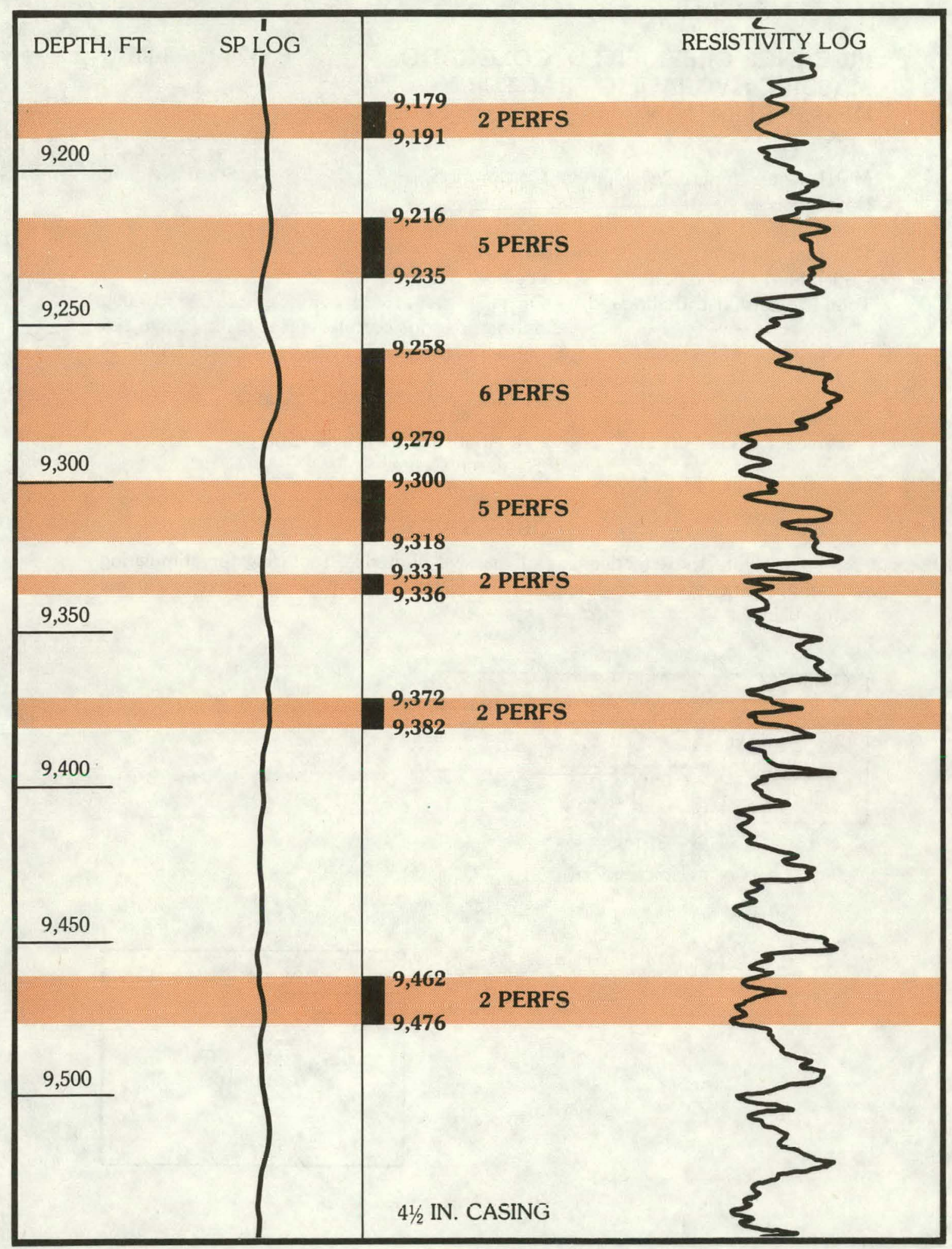

FIGURE 5-8 CONTINUED 
PICEANCE CREEK FIELD, COLORADO,

EY-76-C-08-0678 MASSIVE HYDRAULIC FRACTURING DEMONSTRATION

Mobil Research and Development Corporation

Status: Active

Dallas, Texas

Contract Date:

Anticipated Completion:

July 1, 1976

Total Project Cost: (Estimated)

December 31, 1978

DOE ...................... \$2,510,000

Contractor (prior costs) . . ........ 2,376,485

Contractor (new costs) . . . . . . . 1,590,515

Total .................. \$6,477,000

Principal linvestigator:

Inhn I.. Fitch

Technical Fıvject Officer:

C. H Atkinson, Bartlesville Energy

Research Center

\section{OBJECTIVE}

To evaluate the effectiveness of massive hydraulic fracturing for stimulating natural gas production from thick, deep sandstone reservoirs having extremely low permeability.

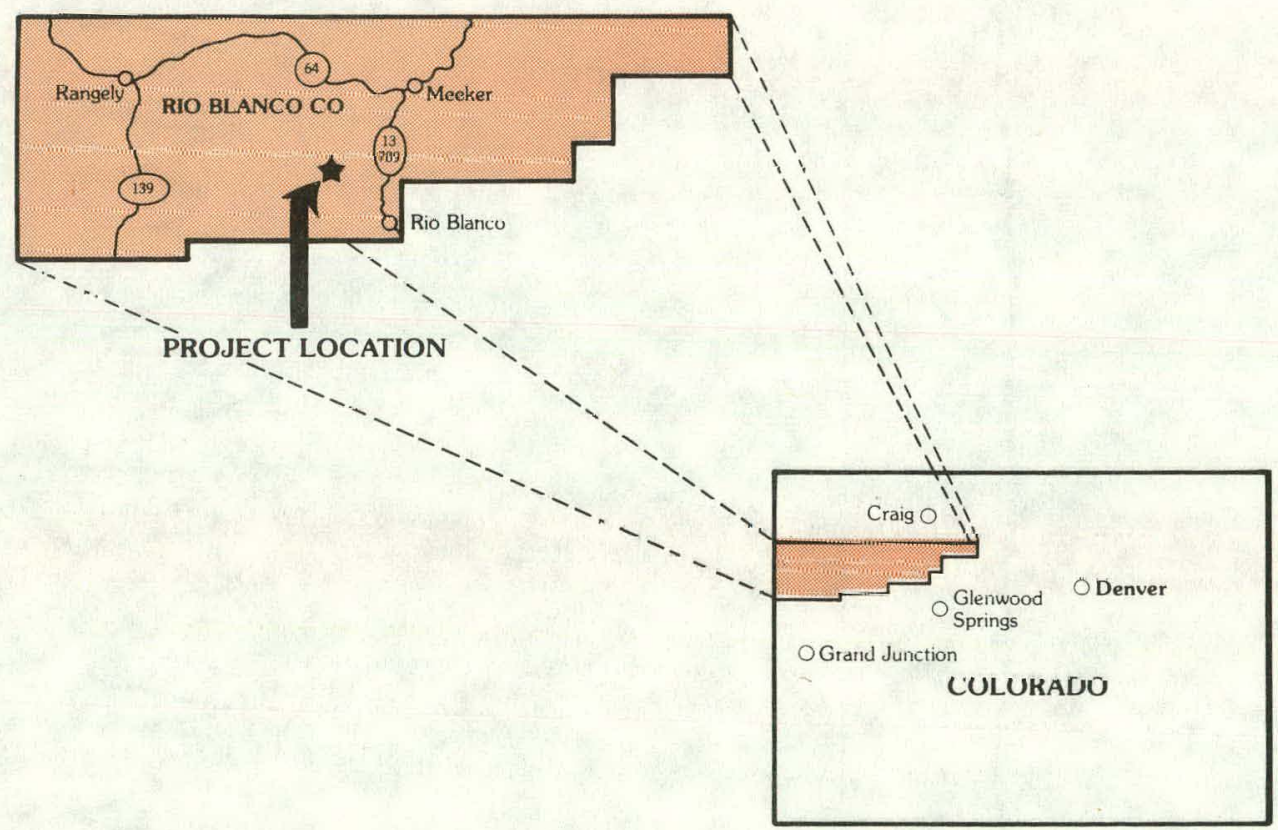




\subsection{Mobil Research and Development Corporation}

\subsubsection{Scope of Work}

Mobil was awarded DOE Contract EY-76-C-08-0678, originally in the amount of $\$ 2.6$ million for a MHF experiment in Rio Blanco County, Colorado. The scope of work under the contract is to be performed in three phases involving a well, F-31-13G, which was drilled in the Piceance Creek Gas Field, Rio Blanco County, Colorado.

\subsubsection{Current Status}

The Mobil Well F-31-13G produced to the pipeline throughout the month of February. Production data are given in Table 5-2. As of March 9 the well was making 1.26 MMCFD. Plans for resuming work on the well about April 1 are proceeding on schedule. 
TABLE 5-2 MOBIL WELL F-31-13G PRODUCTION DATA

\begin{tabular}{|c|c|c|c|c|c|}
\hline Date & $\begin{array}{c}\text { Gas } \\
\text { MMCFD }\end{array}$ & $\begin{array}{c}\text { Condensate } \\
\text { BPD }\end{array}$ & $\begin{array}{l}\text { Water } \\
\text { BPD }\end{array}$ & $\begin{array}{l}\text { T.P. } \\
\text { psi }\end{array}$ & $\begin{array}{l}\text { C.P. } \\
\text { psi }\end{array}$ \\
\hline $2 / 1$ & - & - & - & - & - \\
\hline $2 / 2$ & - & - & - & - & - \\
\hline $2 / 3$ & 1.61 & 20 & 85 & 370 & 909 \\
\hline $2 / 4$ & 1.61 & 20 & 85 & 370 & 909 \\
\hline $2 / 5$ & 1.57 & 19 & 80 & 370 & 909 \\
\hline $2 / 6$ & 1.57 & 19 & 80 & 370 & 891 \\
\hline $2 / 7$ & 1.57 & 18 & 80 & 370 & 882 \\
\hline $2 / 8$ & 1.51 & 17 & 75 & 370 & 873 \\
\hline $2 / 9$ & 1.51 & 16 & 75 & 315 & 808 \\
\hline $2 / 10$ & 1.59 & 16 & 75 & 304 & 800 \\
\hline $2 / 11$ & 1.54 & 16 & 70 & 304 & 795 \\
\hline $2 / 12$ & 1.53 & 16 & 70 & 294 & 795 \\
\hline $2 / 13$ & 1.51 & 16 & 65 & 294 & 777 \\
\hline $2 / 14$ & 1.51 & 16 & 65 & 294 & 777 \\
\hline $2 / 15$ & 1.51 & 16 & 65 & 294 & 777 \\
\hline $2 / 16$ & 1.51 & 16 & 6.5 & 294 & 777 \\
\hline $2 / 17$ & 1.50 & 16 & 55 & 294 & 770 \\
\hline $2 / 18$ & 1.48 & 17 & 55 & 294 & 765 \\
\hline $2 / 19$ & 1.45 & 17 & 50 & 294 & 765 \\
\hline $2 / 20$ & 1.42 & 17 & 45 & 294 & 760 \\
\hline $2 / 21$ & 1.42 & 18 & 45 & 294 & 755 \\
\hline $2 / 22$ & 1.44 & 18 & 4.5 & 294 & 750 \\
\hline $2 / 23$ & 1.39 & 18 & 45 & 294 & 750 \\
\hline $2 / 24$ & 1.41 & 16 & 40 & 294 & 747 \\
\hline $2 / 25$ & 1.37 & 16 & 40 & 294 & 747 \\
\hline $2 / 26$ & 1.35 & 16 & 40 & 294 & 747 \\
\hline $2 / 27$ & 1.37 & 16 & 40 & 294 & 747 \\
\hline $2 / 28$ & 1.35 & 16 & 40 & 294 & 747 \\
\hline
\end{tabular}




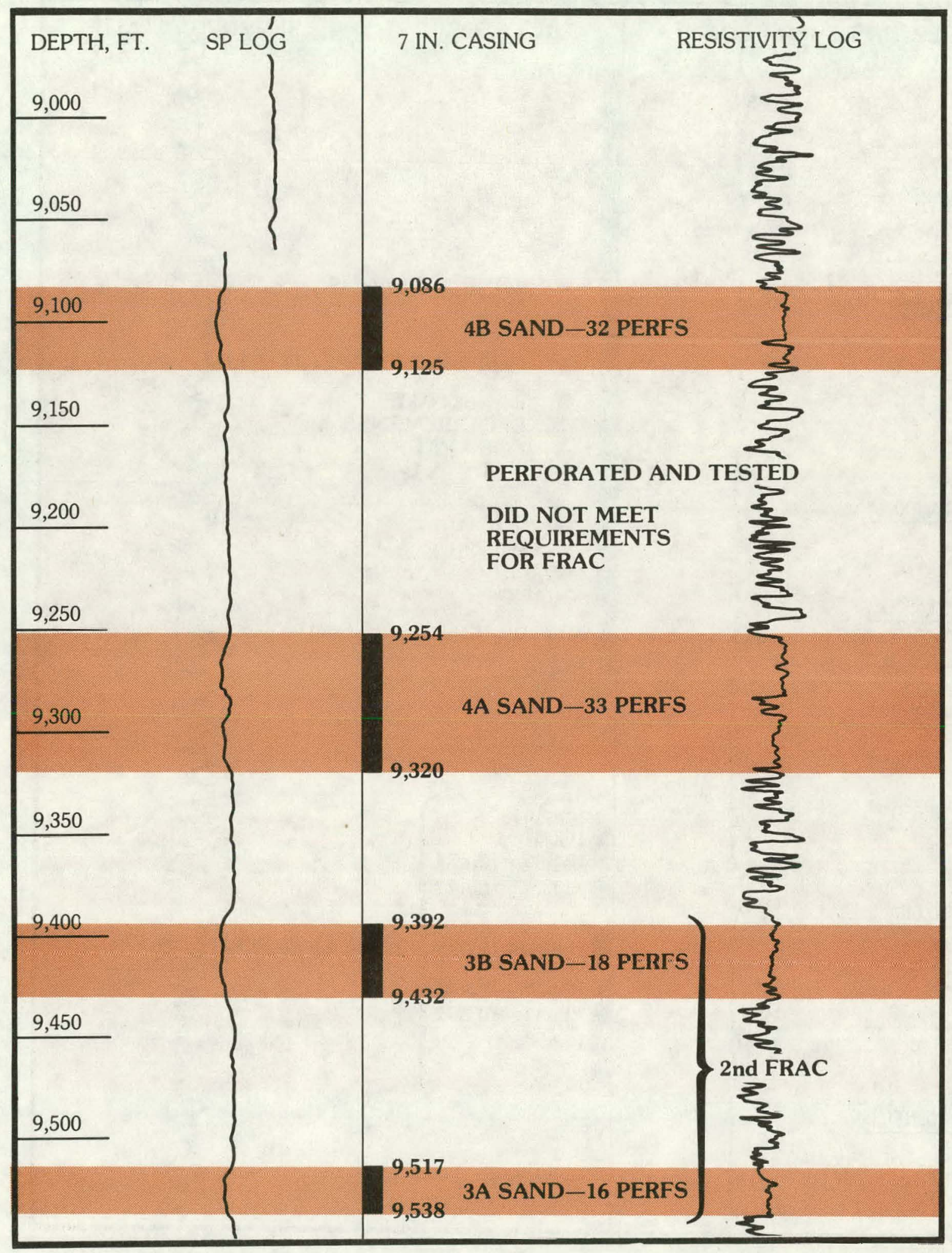

FIGURE 5-9 MOBIL F-31-13G WELL SHOWING SANDS FRACTURED 


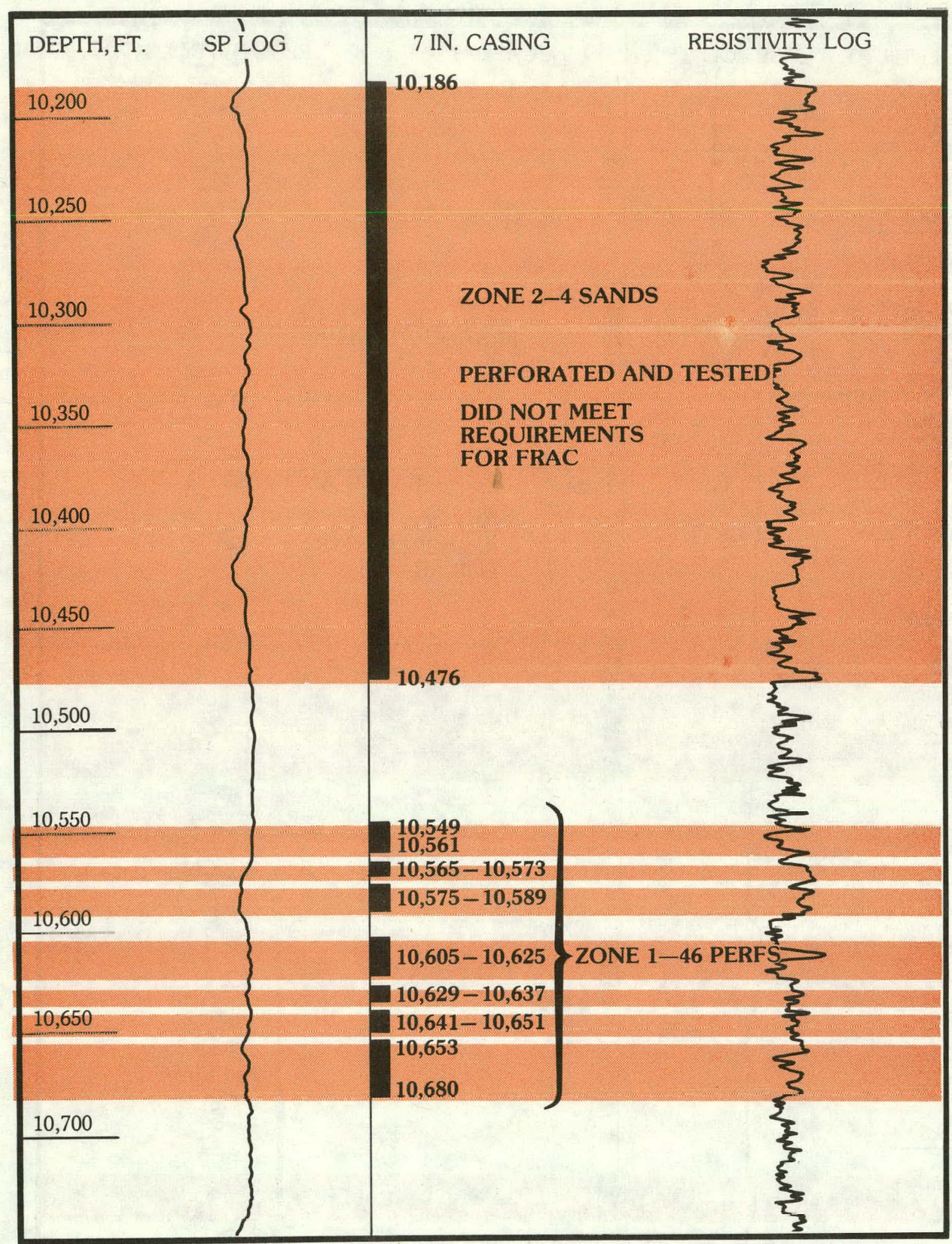

FIGURE 5-9 CONTINUED 


\section{DEMONSTRATION}

Rio Blanco Natural Gas Company

Denver, Colorado

Status: Active

Contract Date:

Anticipated Completion:

Total Project Cost: (Estimated)

Principal Investigator:

Technical Project Officer:

August 1, 1976

March 31, 1978

DOE ..................... \$ 410,000

Contractor ................ 593,000

Total .................. $\$ 1,003,000$

Robert E. Chancellor

C. H. Atkinson, Bartlesville Energy

Research Center

\section{OBJECTIVE}

To evaluate the effectiveness of massive hydraulic fracturing for stimulating natural gas production from thick, deep sandstone reservoirs having extremely low permeability.

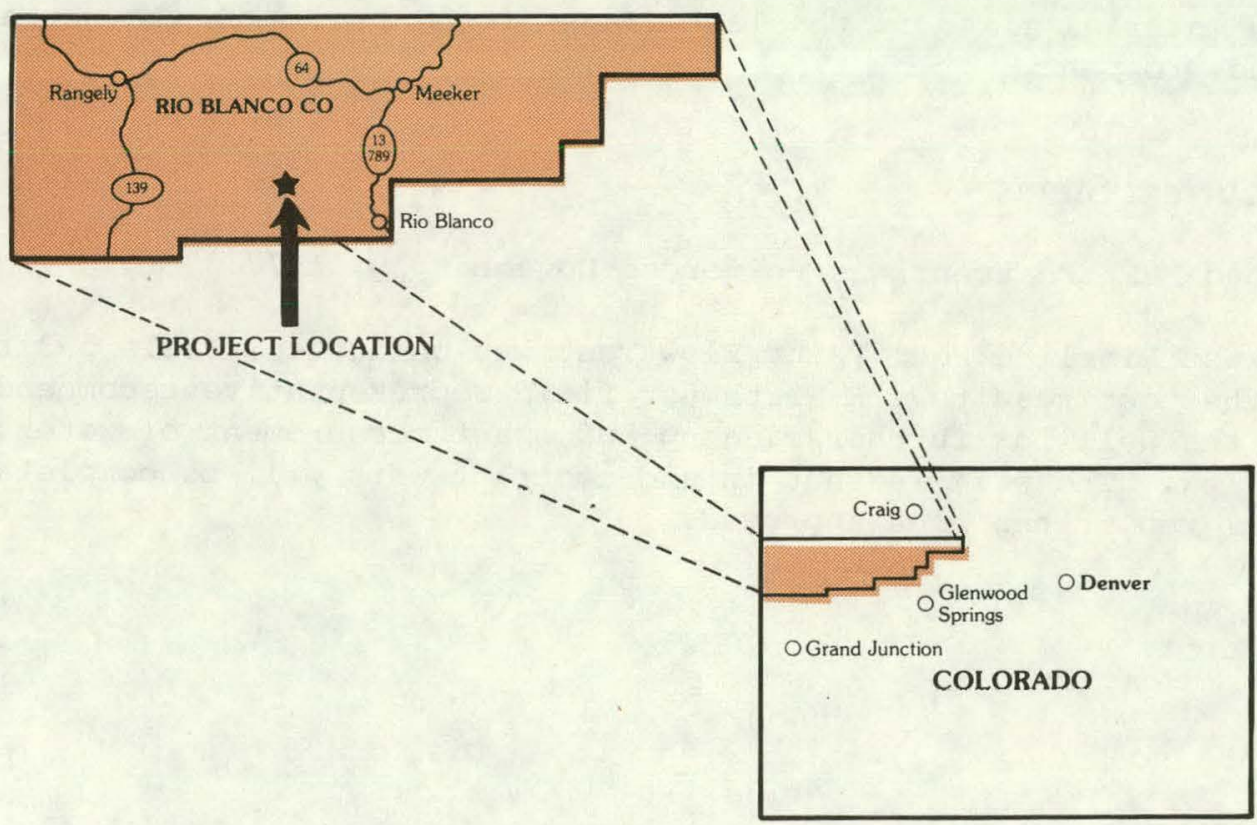




\subsection{Rio Blanco Natural Gas Company}

\subsubsection{Summary of Past Activities}

DOE Contract EY-76-C-08-0677 was signed with Rio Blanco Natural Gas Company in June, 1976. The intention of the work was to prepare an existing well (Federal 498-4-1) for a MHF treatment. This well, located in Section 4, T4S, R98W, Rio Blanco County, Colorado, was drilled and cased to a total depth of 6,963 ft in March, 1975. The Mesaverde Formation was stimulated in two separate treatments before the contract MHF was performed.

The first MHF treatment was performed October 22, 1976. A total of 276,000 gal of fluid was used for the treatment of which 12,000 gal were used as pad. The remaining fluid carried a total of 775,000 ib of sand.

\subsubsection{Contract Modifications for an Additional Fracture}

DOE and Rio Blanco Natural Gas Company entered into a supplemental agreement, effective october 1, 1977. The scope of work is to determine whether the previous fracture may have closed due to proppant crushing or whether it would be beneficial to perform an additional fracture. The new fracture treatment includes $12 / 20$ mesh glass beads as a high strength propping material mixed in the last stage of the frac with the normallyused sand proppant.

\subsubsection{Current Status}

The second MHF treatment was performed November 30, 1977.

A Northwest Pipeline Four Point Flow Test was conducted; Table 5-3 reflects the test results. A Northwest field representative recommended flowing the well for further cleanup and exact measurement of water rate during flow. The well is shut in and contract work will be complete when the final report has been approved. 
TABLE 5-3 RIO BLANCO NATURAL GAS NO. 498-4-1 WELL, FOUR POINT FLOW TEST

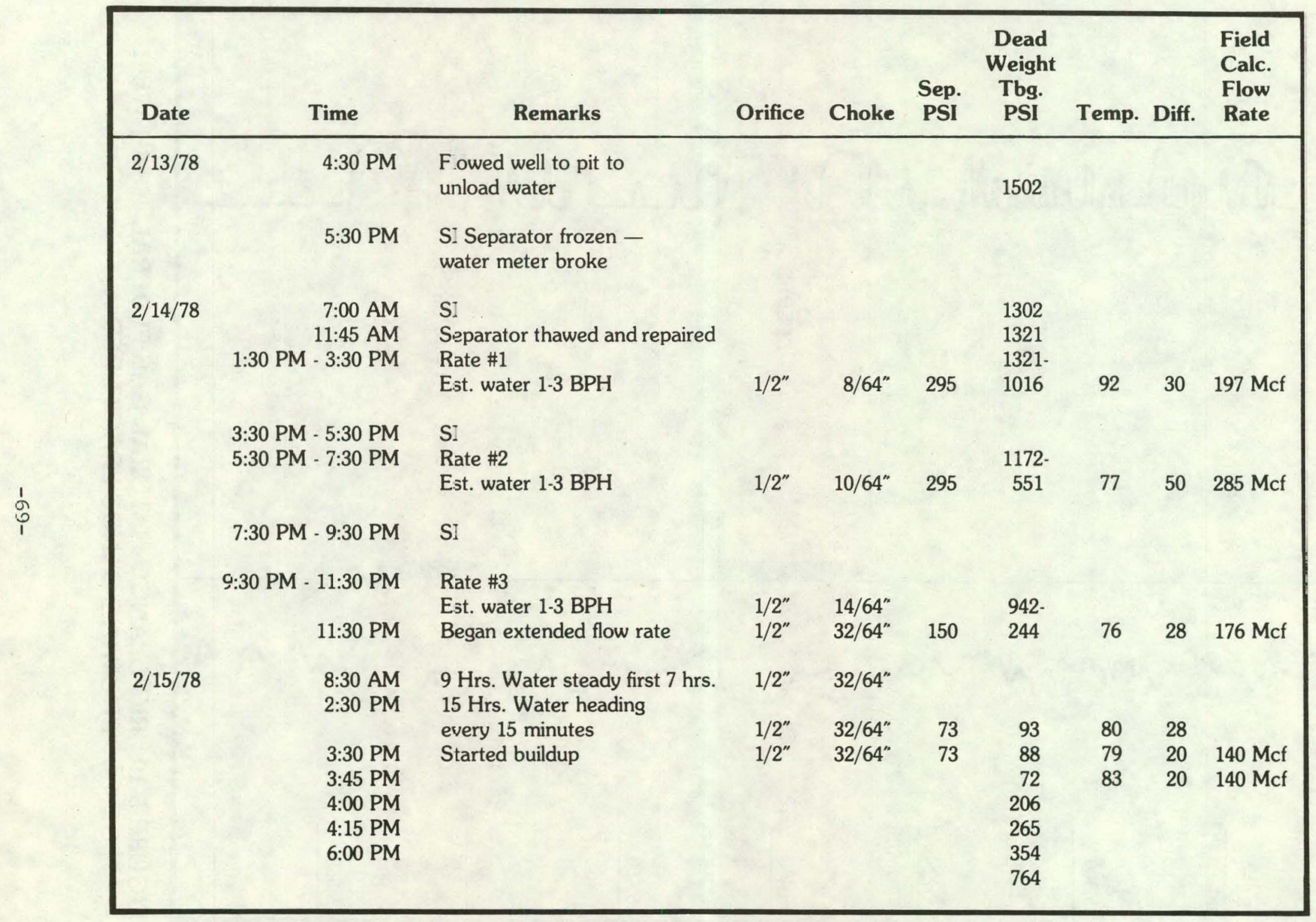




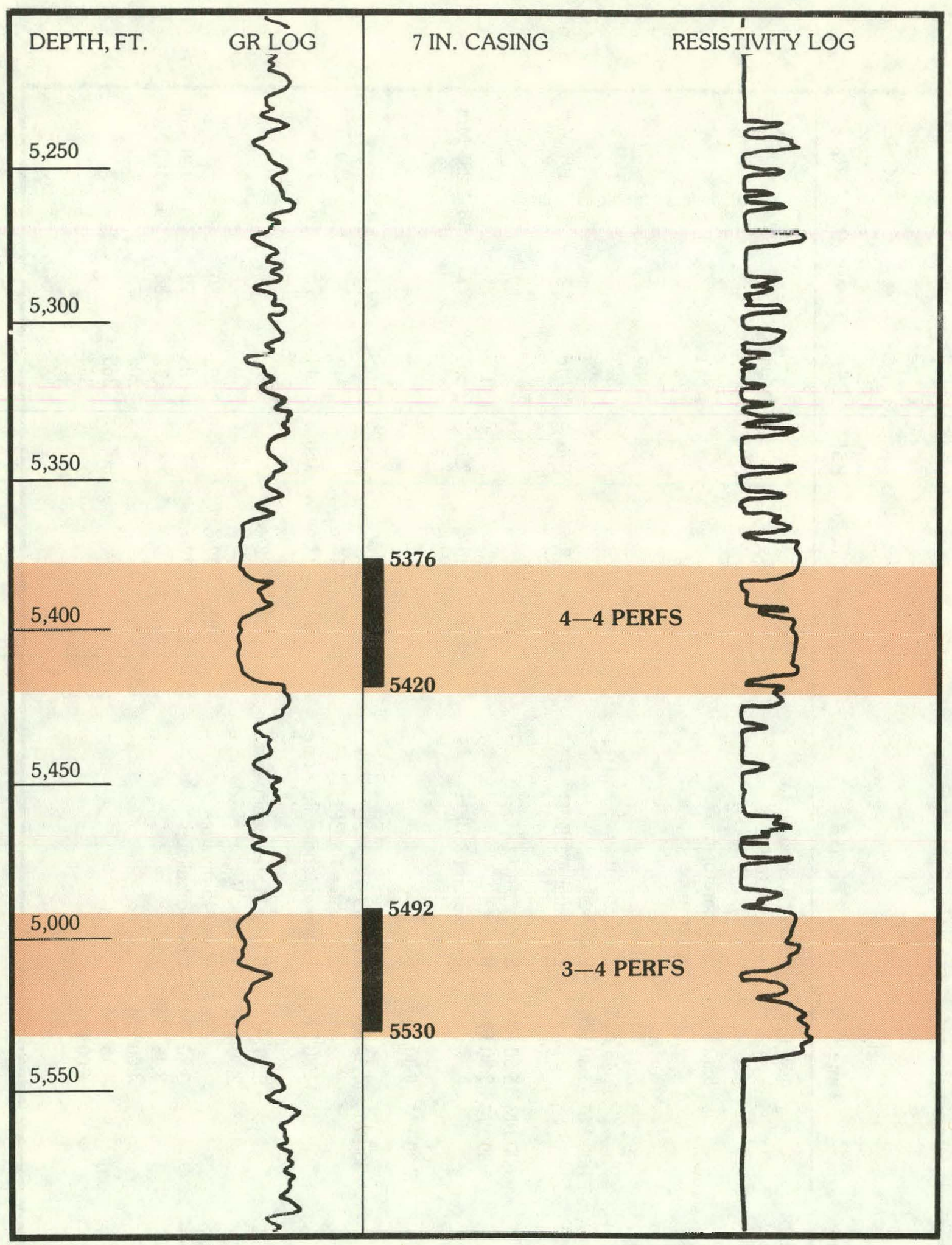

FIGURE 5-10 RIO BLANCO NATURAL GAS FEDERAL 498-4-1 WELL SHOWING SANDS FRACTURED 


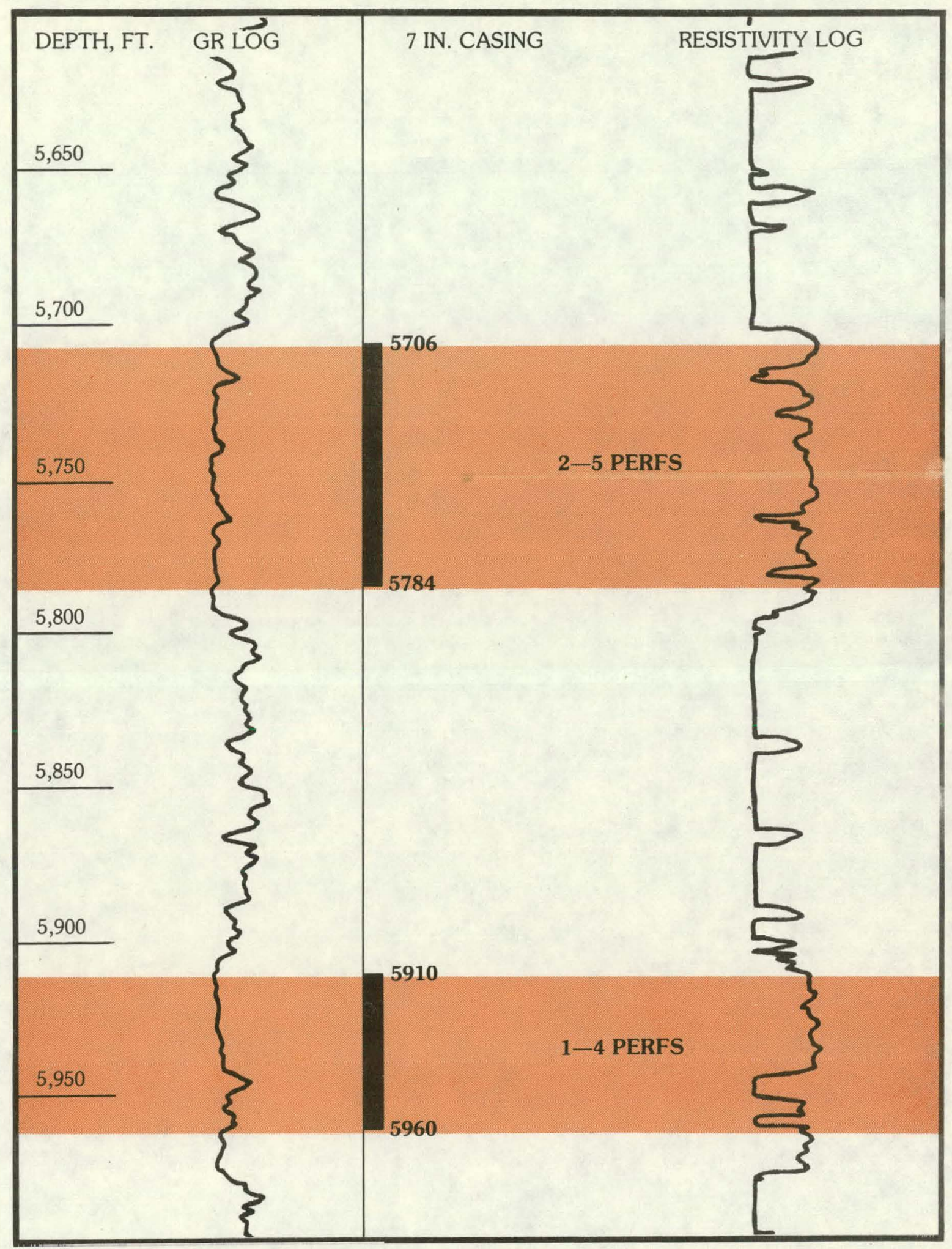

FIGURE 5-10 CONTINUED 